
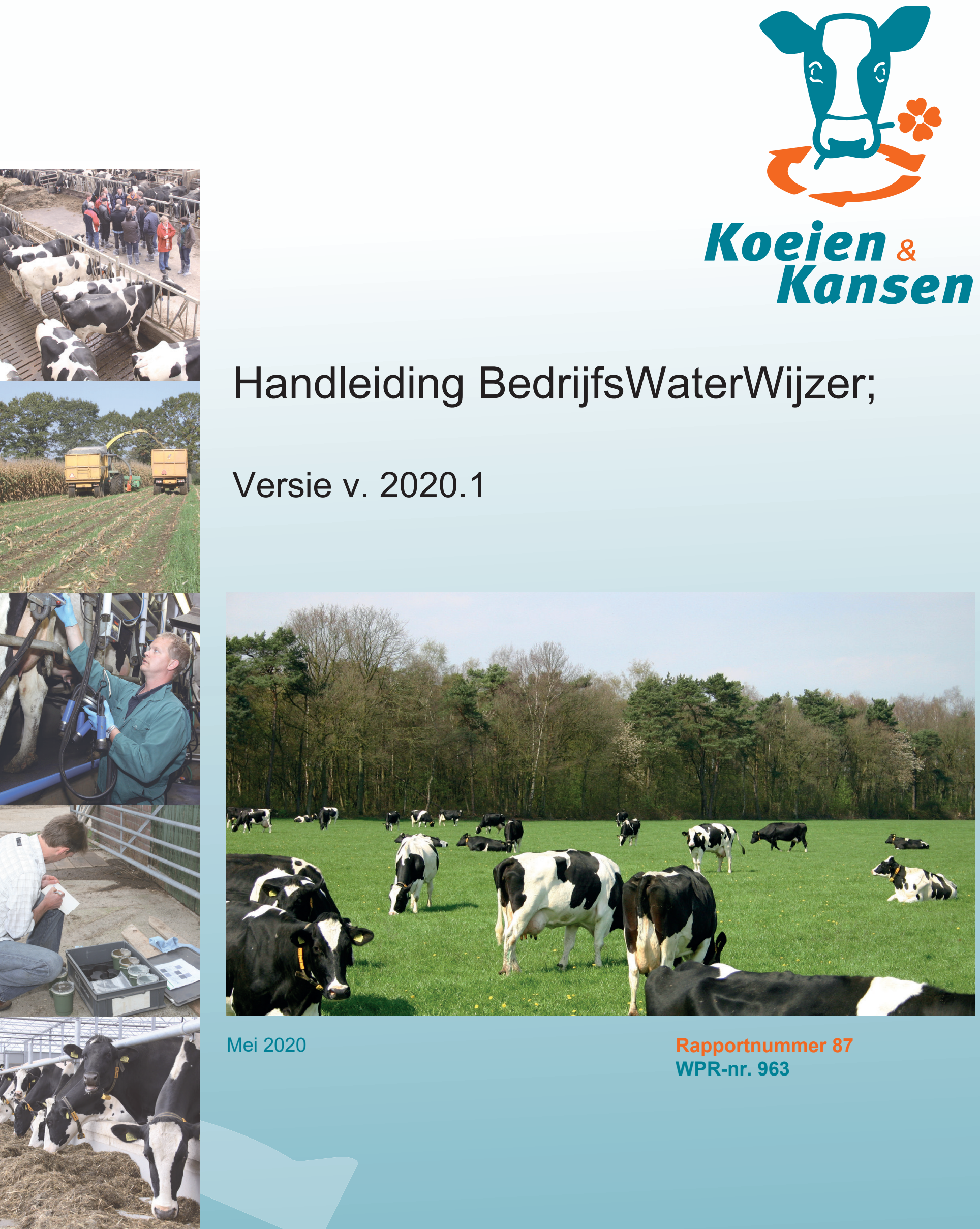

Handleiding BedrijfsWaterWijzer;

Versie v. 2020.1

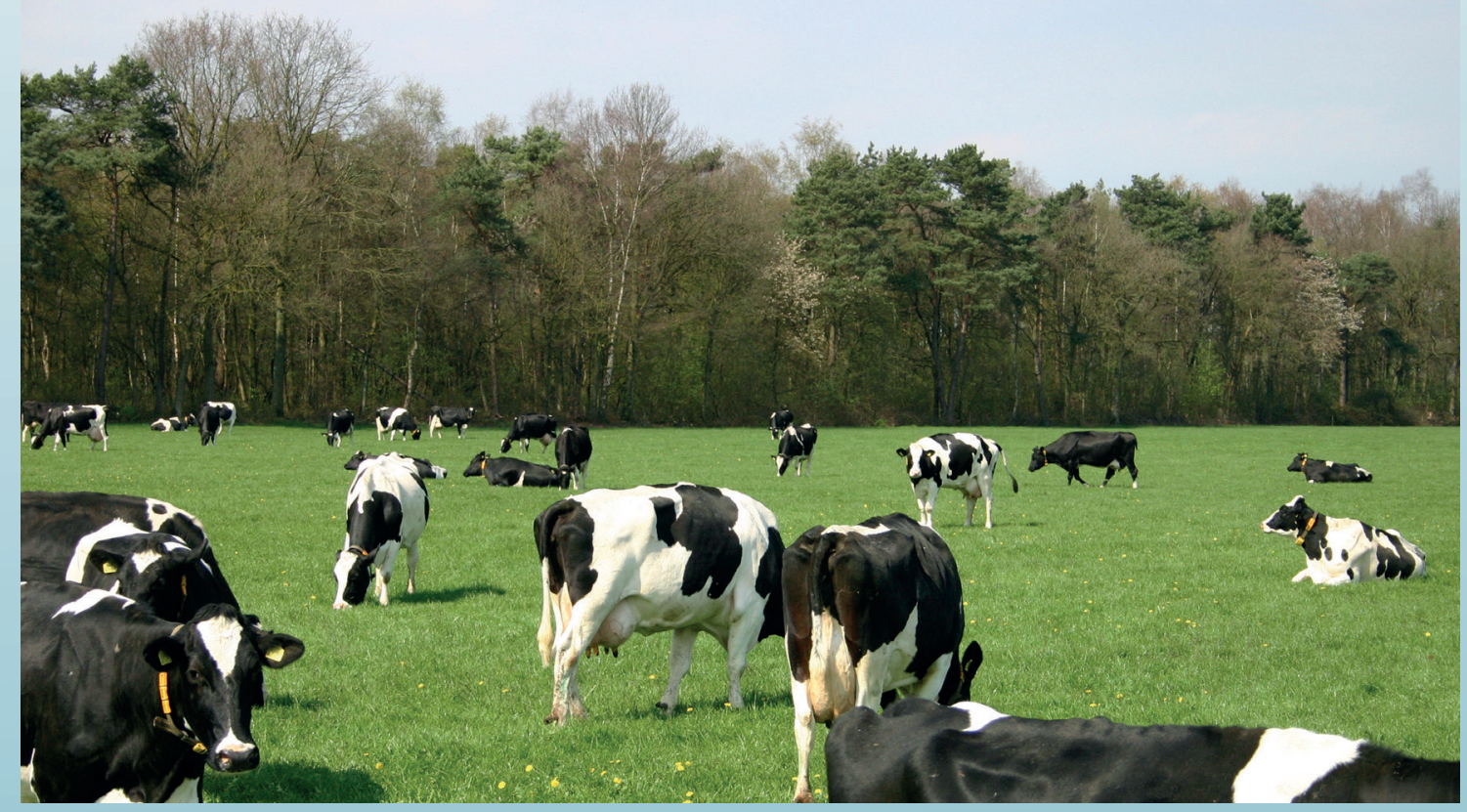

Mei 2020

Rapportnummer 87

WPR-nr. 963 


Koejen \&
Konsen
Uitgever
Wageningen Livestock Research
Postbus 338, 6700 AH Wageningen
T (0317) 48 01 77
E info@koeienenkansen.nl
www.koeienenkansen.nl
Redactie
Koeien \& Kansen
Aansprakelijkheid
Wageningen Livestock Research aanvaardt
geen aansprakelijkheid voor eventuele schade
voortvloeiend uit het gebruik van de resultaten
van dit onderzoek of de toepassing van de
adviezen. All rights reserved.
Bestellen
ISSN 0169-3689
Dit rapport is gratis te downloaden op de website:
https://doi.org/10.18174/521430
(ans

Koeien \& Kansen werkt aan een duurzame en toekomstgerichte melkveehouderij.

Koeien \& Kansen is een samenwerkingsverband van 16 toekomstgerichte melkveehouders, proefbedrijf De Marke, Wageningen University \& Research en adviesdiensten. Met subsidie van de Ministeries van LNV en I\&W en in opdracht van het georganiseerde bedrijfsleven toetst, evalueert en verbetert het project de effectiviteit en uitvoerbaarheid van (voorgenomen) diverse wet- en regelgeving onder praktijkomstandigheden en ondersteunt het de Nederlandse melkveehouderijsector bij de implementatie ervan. De resultaten van Koeien \& Kansen vindt $u$ op:

www.koeienenkansen.nl. Voor vragen kunt u mailen naar: info@koeienenkansen.nl.

Dit onderzoek is uitgevoerd binnen de PPS Meerwaarde Mest en mineralen (TKI-AF-12178) en met subsidie van de Ministeries van LNV en I\&W en de brancheorganisatie ZuivelNL. 
Koeien \& Kansen werkt aan een duurzame en toekomstgerichte melkveehouderij

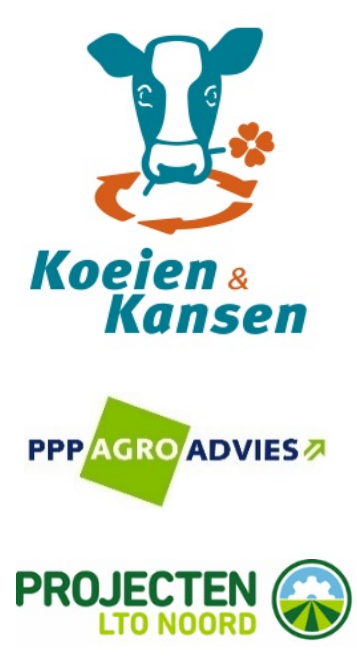

\title{
Handleiding BedrijfsWaterWijzer
}

\author{
Versie v. 2020.1
}

Koos Verloop ${ }^{1}$, Bas Bassa², Dick Jan Koster ${ }^{3}$, Ben Verwijs ${ }^{1}$

\author{
${ }^{1}$ Wageningen University \& Research \\ 2 Projecten LTO Noord \\ ${ }^{3}$ PPP Agro Advies
}





\section{Inhoudsopgave}

$1 \quad$ Algemeen

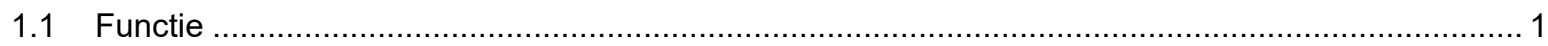

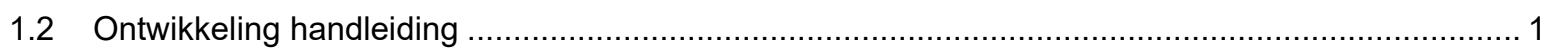

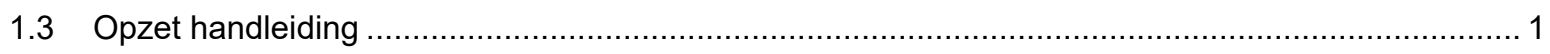

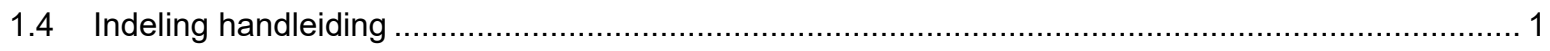

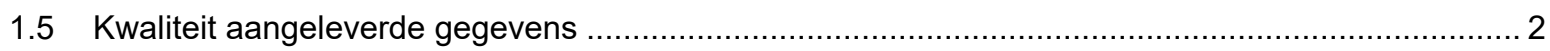

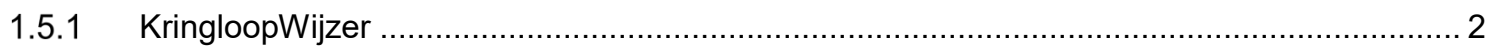

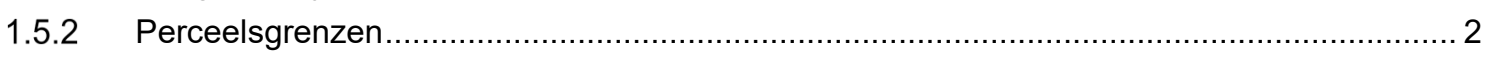

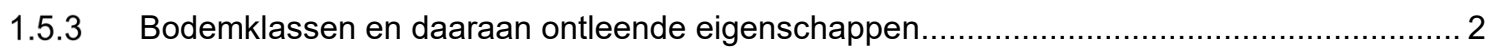

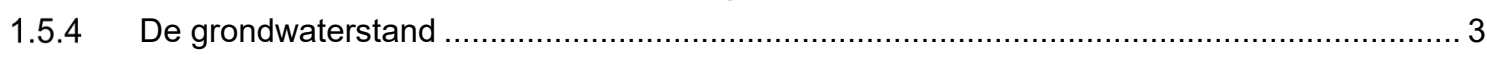

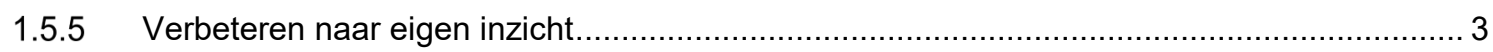

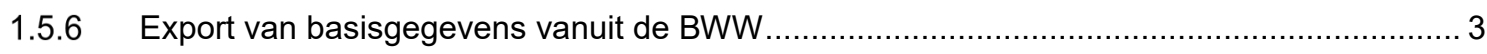

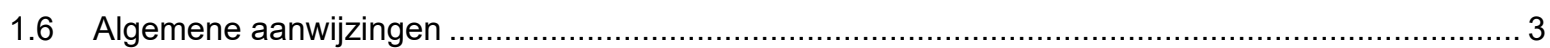

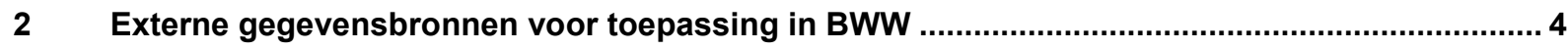

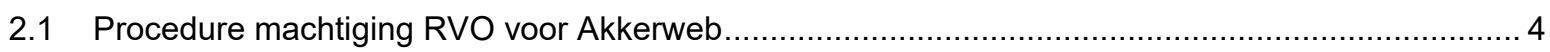

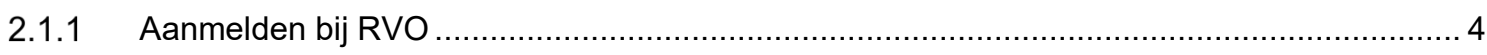

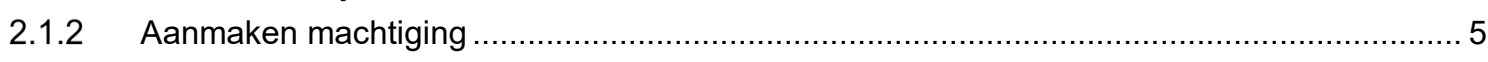

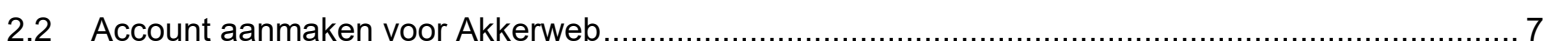

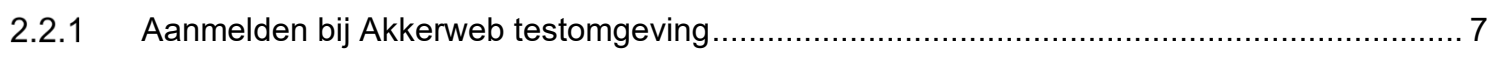

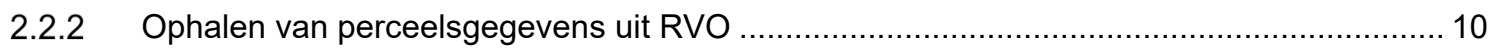

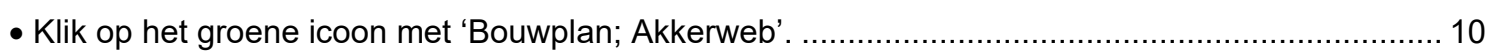

2.3 Gegevens KringloopWijzer exporteren voor invoer in BedrijfsWaterWijzer .................................... 12

3 Inloggen via Akkerweb en wisselen van bedrijf binnen de BWW ..........................................14

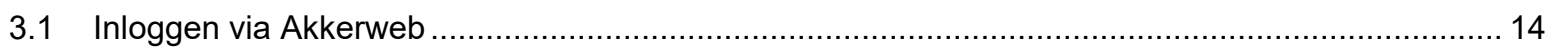

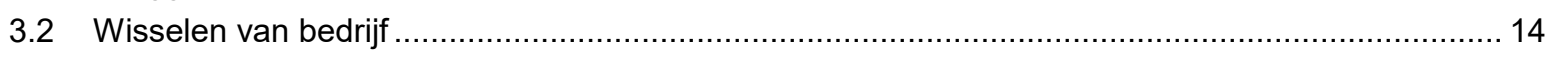

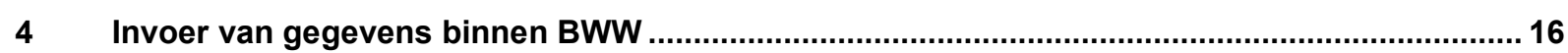

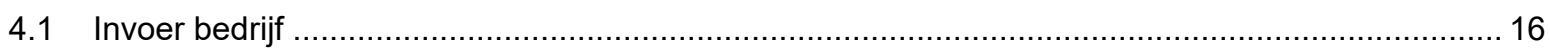

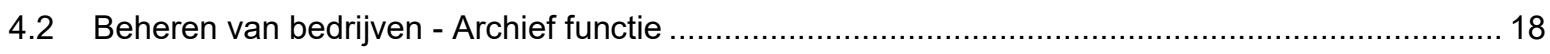

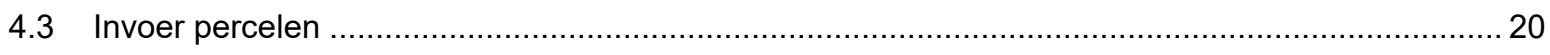

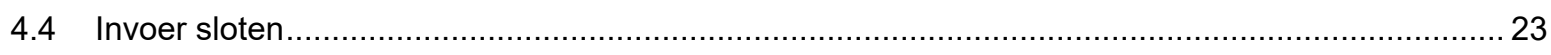

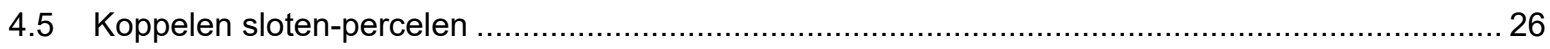

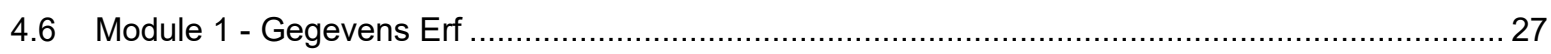

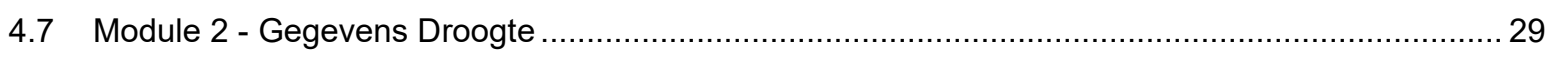

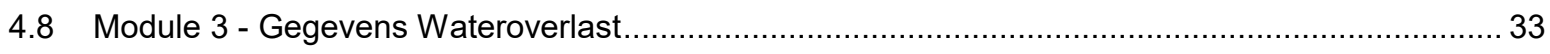

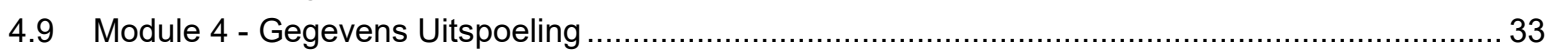

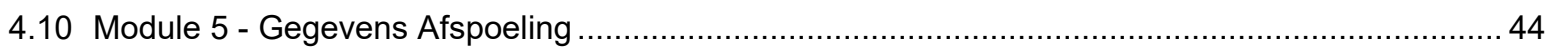

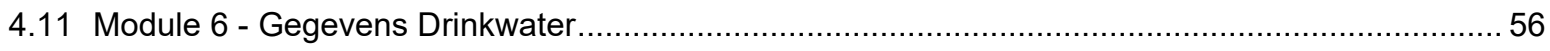

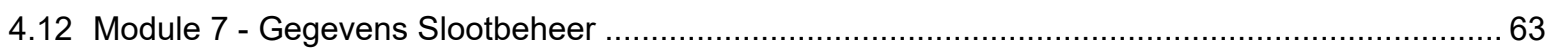




\section{Algemeen}

\subsection{Functie}

Watermanagement van het melkveebedrijf moet toegesneden zijn naar de eisen en wensen van nationale en regionale overheden, de melkverwerker en natuurlijk naar die van het bedrijf zelf. De

BedrijfsWaterWijzer (BWW) heeft als doel om op een praktische en transparante manier op deze wensen in te gaan en belangenafweging te ondersteunen door het watermanagement te karakteriseren op alle relevante aspecten. Het stelt de direct betrokkenen in staat om een bedrijfsspecifiek waterplan te maken om afgesproken doelen aantoonbaar te kunnen realiseren. Door deze bedrijfsspecifieke aanpak kunnen de meest kosteneffectieve maatregelen getroffen worden. Bovendien kan een bedrijfswaterplan prestatieindicatoren produceren die gebruikt kunnen worden bij vergroening van inkomenstoeslagen of bij groenblauwe diensten.

De BWW richt zich op problemen waar de veehouder zelfstandig of in samenwerking met het waterschap of andere regionale partijen wat aan kan doen. Problemen die veroorzaakt worden door bijvoorbeeld de aanvoer van gebiedsvreemd water, liggen buiten de directe invloedssfeer van melkveebedrijven en vallen daarmee grotendeels buiten het primaire domein van de BWW.

\subsection{Ontwikkeling handleiding}

De ontwikkeling van de BWW is een cyclisch proces. Dat wil zeggen dat ontwerp, inbouw in software, toetsing en evaluatie telkens terugkomende activiteiten zijn totdat de BWW zijn finale vorm heeft bereikt. Op dit moment is de BWW nog niet geschikt voor gebruik zonder begeleiding. Begeleiding kan bestaan uit hulp van een externe deskundige in combinatie met deze handleiding.

Omdat het programma BWW (nog) in ontwikkeling is, zal de handleiding ook telkenmale moeten worden bijgewerkt. Het versienummer van deze handleiding correspondeert met het versienummer van het programma.

\subsection{Opzet handleiding}

Deze handleiding gaat uitsluitend over de invoer van gegevens in de BedrijfsWaterWijzer. Ondersteunend materiaal over de interpretatie van resultaten is in ontwikkeling.

De BedrijfsWaterWijzer is een online programma waarvoor een aansluiting op het internet noodzakelijk is. Ingevoerde en eventueel gewijzigde gegevens worden online opgeslagen. Resultaten kunnen ook op een lokale computer worden opgeslagen.

De BWW is modulair van opbouw wat bijdraagt aan de overzichtelijkheid van zowel het invoeren van gegevens als het uitlezen van resultaten. Tijdens het invullen of wijzigen van gegevens kan het programma gestopt worden en op een ander moment weer worden hervat. Eerder ingevoerde en/of gewijzigde gegevens gaan niet verloren. In het programma worden geen herkenningspunten aangeduid tot hoever en welke gegevens gewijzigd zijn, maar als er gegevens missen voor het doorrekenen van een module, dan geeft het programma de mogelijkheid om direct naar de invoerpagina van deze gegevens te navigeren.

Wanneer het invullen of wijzigen van een module gereed is, kan via een knop 'Volgende module ' $x x x x x$ ' kan naar een volgende module gegaan worden. Door de modulaire opbouw is het niet noodzakelijk om modules opeenvolgend in te vullen of te wijzigen. Modules kunnen ook 'at random' ingevuld of gewijzigd worden.

\subsection{Indeling handleiding}

Hoofdstuk 2 beschrijft de wijze hoe bij RVO een machtiging toegekend kan worden, een account aangemaakt kan worden in Akkerweb en gegevens van de KringloopWijzer gereed gemaakt kunnen worden voor gebruik in de BedrijfsWaterWijzer. Deze gegevens kunnen in de BedrijfsWaterWijzer 
geïmporteerd worden. Voor dit hoofdstuk is gebruik gemaakt van een door de organisatie Projecten LTO Noord reeds eerder geschreven handleidingen. Voor de continuïteit van het invoeren is deze handleiding (bijna) integraal overgenomen in deze handleiding van de BedrijfsWaterWijzer.

Hoofdstuk 3 geeft een beschrijving hoe via de applicatie Akkerweb ingelogd kan worden. Ook wordt beschreven hoe binnen de BWW van bedrijf gewisseld kan worden zonder dat het laatst gebruikte bedrijf (account) weer automatisch wordt opgestart .

Hoofdstuk 4 bevat een beschrijving hoe eerst de onderdelen percelen en sloten moeten worden ingevoerd en bewerkt en hoe percelen en sloten aan elkaar gekoppeld moeten worden. Daarna volgt per module een beschrijving van het invoeren en bewerken van detail gegevens voor de BWW.

Module 1 in hoofdstuk 4 (Erfwater) wordt ingevuld in de AgriWijzer van Broos Water. Dit is een bestaand internet-programma dat al eerder ontwikkeld was en dat breed beschikbaar is. De AgriWijzer is in overleg met Koeien en Kansen aangepast zodat het programma optimaal aansluit bij de BWW doelen. Hiertoe is in de AgriWijzer een nieuwe aansluiting op de BWW gebouwd. Vervolgens is de 'gebruikers-route' en de informatie-uitwisseling tussen AgriWijzer en BWW geprogrammeerd.

\subsection{Kwaliteit aangeleverde gegevens}

\subsubsection{KringloopWijzer}

Bedrijfsinformatie met betrekking tot stikstof en fosfaat wordt ingelezen uit de KringloopWijzer.

\subsubsection{Perceelsgrenzen}

De geografische basis voor het definiëren van de percelen volgt de Basis Registratie Percelen (BRP) zoals opgegeven aan RVO. Met de contouren van de percelen worden vervolgens uit de door WUR ontsloten Top-10 kaart van Nederland de contouren en gegevens van aanliggende sloten en waterpartijen geïmporteerd. Door de perceel- en slootgegevens op deze wijze in te lezen, worden fouten voorkomen en is er continuïteit in de gegevens. Bovendien scheelt het importeren tijd ten opzichte van het handmatig invoeren.

\subsubsection{Bodemklassen en daaraan ontleende eigenschappen}

De contouren van de BRP percelen worden in een webservice bij WEnR over de bodemkaart gelegd om te bepalen welke bodemtypen er binnen het perceel voorkomen. Deze bodemtypen (er worden 315 bodemtypen onderscheiden binnen de grondsoorten zand, klei, veen en leem) worden doorgegeven aan de BWW en vertaald naar de bodemclassificatie (waarin 10 klassen worden onderscheiden). Vervolgens wordt de klasse die overheerst bepaald. De betrouwbaarheid van deze toedeling van bodemklassen is afhankelijk van de betrouwbaarheid van de 1:50.000 bodemkaart. In de BWW is de versie van de bodemkaart van 2018 gebruikt en die is opgenomen in de BRO, beschikbaar op PDOK. In het algemeen kan worden gesteld dat de betrouwbaarheid van de 1:50.0000 bodemkaart $70 \%$ is, dat wil zeggen dat de kans dat een plek in Nederland inderdaad het aangegeven bodemtype op kaart heeft, $70 \%$ is. Dat lijkt misschien heel laag, maar hierbij moet worden bedacht dat de bodemkaart 315 bodemtypen onderscheidt binnen de grondsoorten zand, klei, veen en leem en dat we deze verschillende bodemtypen opnemen in een grovere indeling van 10 klassen. Aangezien aangrenzende bodemtypen meestal tot dezelfde klasse behoren, zal de nauwkeurigheid van de grovere indeling hoger zijn dan $70 \%$. Ook komt het regelmatig voor dat aangrenzende bodemtypen vrijwel dezelfde eigenschappen hebben omdat er een geleidelijke overgang bestaat in de dikte van een bodemlaag, bijvoorbeeld klei-op-veen. Als de kleilaag net $<40 \mathrm{~cm}$ dik is behoort de plek tot de veengronden en $>40 \mathrm{~cm}$ dik tot de kleigronden. Degelijke overgangen bestaan er ook voor veen en zand (moerige lagen), klei en zand, etc. Ook bestaat er een dergelijke overgang tussen podzolen ( $<40 \mathrm{~cm}$ humusrijke bovengrond) en enkeerdgronden ( $>40 \mathrm{~cm}$ humusrijke bovengrond), in onze classificatie zandgronden met meer of minder dan $30 \mathrm{~cm}$ humusrijke bovengrond. In dergelijke gevallen is er dus wel $30 \%$ kans dat de bodemtype aanduiding niet juist is, maar dat zal voor de eigenschappen van het perceel niet veel uitmaken. Op dit detailniveau is het oordeel van de boer over plekken in zijn perceel waarschijnlijk meer doorslaggevend dan de bodemkaart. Voor een meer gedetailleerde lokalisatie van de bodemtypen binnen een bedrijf is ervaring van een veldbodemkundige nodig. Dan komt in beeld dat de ruimtelijke variabiliteit in het veld groter is dan de bodemkaart aangeeft. Bij het maken van de bodemkaart is gemiddeld één boring per 5 à 6 ha uitgevoerd. 


\subsubsection{De grondwaterstand}

De actuele Grondwatertrap (gt, een klasse indeling voor de grondwaterstand) is afgeleid van de GD, dat staat voor GrondwaterDynamiek. Resultaat van dit project zijn geschatte grondwaterstandsverlopen op ieder punt in het landelijk gebied van Nederland. Deze schattingen zijn alleen voor het hoge deel van Nederland beschikbaar; de schattingen voor laag Nederland zijn nog in ontwikkeling. Voor laag Nederland hebben we de GT op basis van karteerbare eigenschappen gebruikt (van der Gaast et al., 2010: https://edepot.wur.nl/163486). De intentie is om deze aanvulling op termijn te vervangen door de gd voor laag Nederland. Momenteel hebben we hierdoor in het overgangsgebied van hoog naar laag NL te maken met grensverschijnselen. Aan weerszijden van de grens tussen beide gt schattingen blijkt een duidelijk verschil dat een gevolg is van de twee verschillende methoden.

De Gt-actualisatie in Hoog Nederland op basis van GD is gebaseerd op geregistreerde grondwaterstandsverlopen uit TNO-buizen en een geostatistische interpolatie daartussen rekening houdend met de hoogte van het maaiveld (AHN). De nauwkeurigheid van de schattingen hangt onder andere. af van de dichtheid van, ofwel de afstand tussen, de meetpunten. Zo kan het voorkomen dat een punt binnen een grondwaterintrekgebied een lagere grondwaterstand heeft dan ingeschat met GD omdat er geen TNO-buis binnen dat gebied ligt, die een lokale laagte in de grondwaterstand kan registreren. Het is dus in alle gevallen zaak om ingeschatte grondwatertrappen op een bedrijf te toetsen aan de veldkennis van de boer, net zoals dat al werd aanbevolen bij de bodemklassen.

\subsubsection{Verbeteren naar eigen inzicht}

Onvolkomenheden in de geïmporteerde gegevens kunnen door de gebruiker in de BWW gecorrigeerd worden waardoor de gegevens de werkelijkheid zo correct mogelijk weerspiegelen. De kwaliteit en dus betrouwbaarheid van de uit andere diensten geïmporteerde gegevens is afhankelijk van de kwaliteit van de bij de andere diensten ingevoerde gegevens en de processing daarvan bij de andere diensten. Controleren voor de juistheid van de gegevens blijft dus noodzaak.

\subsubsection{Export van basisgegevens vanuit de BWW}

De in de BWW geïmporteerde en daarna in de BWW gecorrigeerde gegevens of nieuwe toegevoegde gegevens, zoals van percelen, kunnen niet vanuit de BWW geëxporteerd worden naar de basisregistratie van RVO of rechtstreeks geïmporteerd worden in de KringloopWijzer.

\subsection{Algemene aanwijzingen}

De BWW en daarmee deze handleiding zijn nog in een fase van ontwikkeling. Die fase komt steeds verder richting het einddoel. Het blijft echter mogelijk dat er onverwachte situaties voordoen waardoor de BWW vastloopt of een onderdeel van het veehouderijbedrijf niet of beperkt ingepast kan worden in een module van de BWW. Graag zouden wij van deze onvolkomenheden op de hoogte worden gebracht. U kunt dit doen door een e-mail te sturen aan 'info@koeienenkansen.nl'. In dit bericht graag aangeven op welke module het punt betrekking heeft, een (korte) omschrijving van het probleem en gegevens waarop we $u$ kunnen bereiken voor eventuele meer informatie. 


\section{Externe gegevensbronnen voor toepassing in BWW}

\subsection{Procedure machtiging RVO voor Akkerweb}

Tijdens het invullen van de gecombineerde opgave geeft u per perceel een aantal kenmerken op. Een deel van deze kenmerken wordt overgenomen in de BedrijfsWaterWijzer. Dat overnemen geschiedt via Akkerweb. Bij RVO dient daarom een machtiging aangemaakt te worden voor Akkerweb zodat de percelen rechtstreeks ingelezen worden vanuit RVO.

In deze paragraaf worden de stappen gegeven die genomen moeten worden om een machtiging bij RVO aan te maken.

\subsubsection{Aanmelden bij RVO}

- Ga naar uw webbrowser en type de volgende link in: https://mijn.rvo.nl.

- Klik op 'Inloggen op mijn.rvo.nl'.
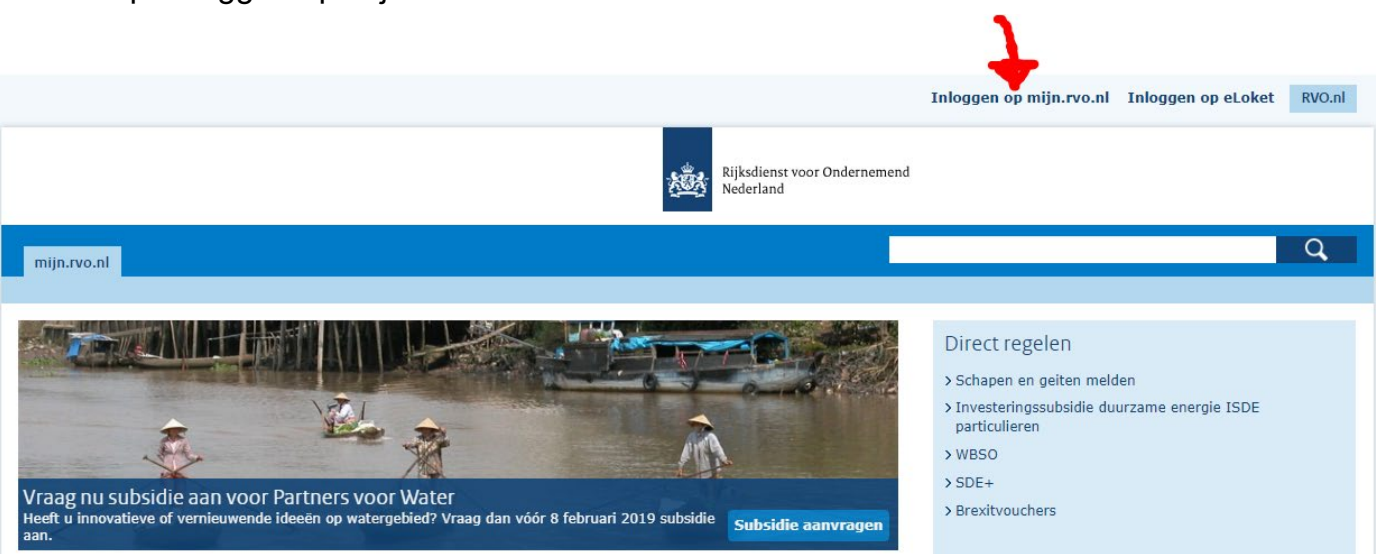

- Log in op de manier zoals u (of uw adviseur) dat gebruikelijk doet. Kies daarvoor uit een van de onderstaande inlogopties.

- Log daarna in volgens de aanwijzingen op de website.

\section{Inloggen}

(1. Het Ministerie van Economische Zaken mag DigiD gebruiken voor de dienstverlening van haar diensten en instellingen. Op wwww.digid.n] en www.minez.n! kunt u nagaan welke diensten en instellingen zijn aangesloten.

\section{Inloggen op mijn.rvo.nl}

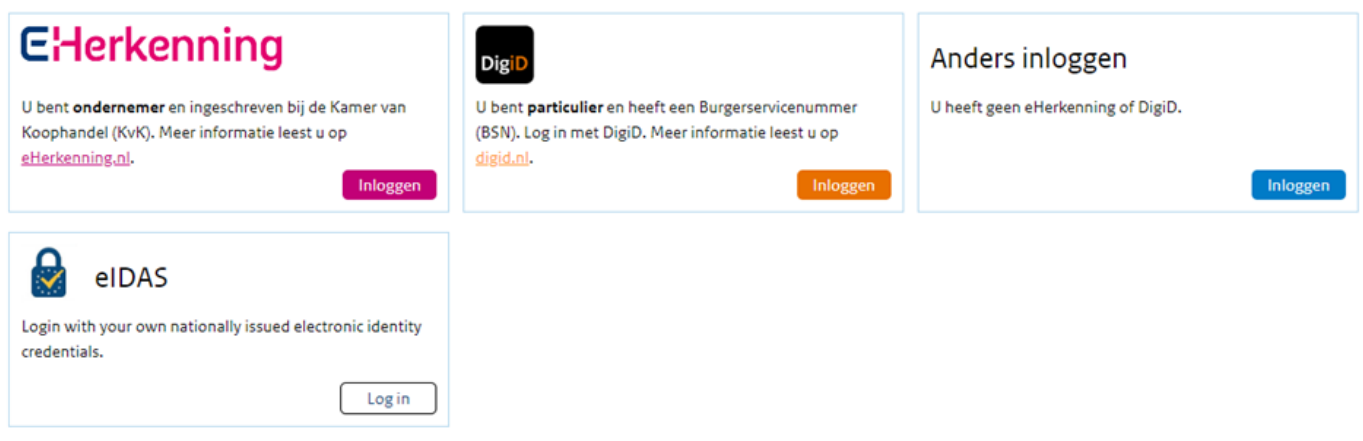




\subsubsection{Aanmaken machtiging}

$\mathrm{Na}$ inloggen verschijnt het startscherm.

- Klik op ‘> Mijn machtigingen’ (zie rode pijl).

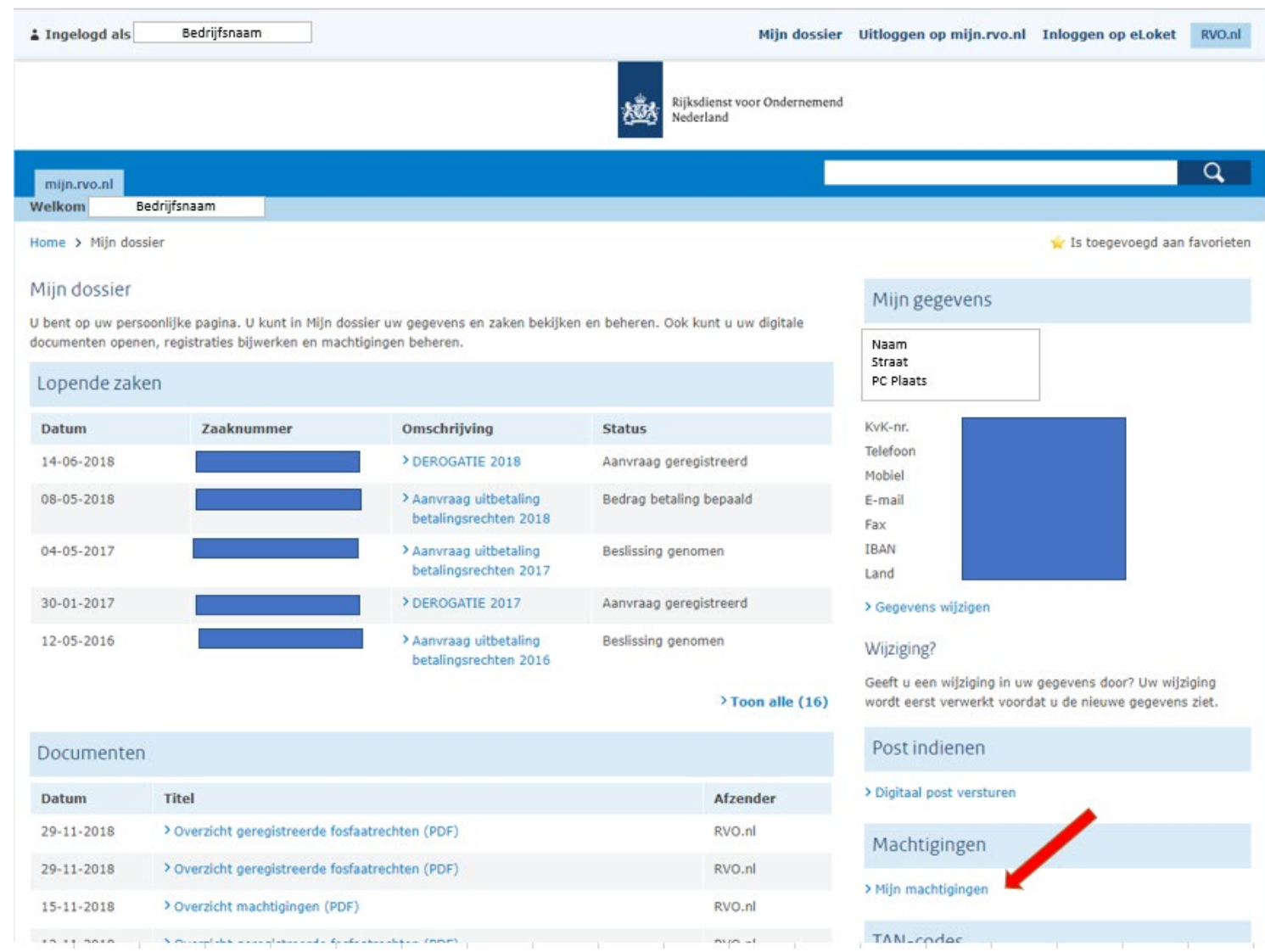

- Het scherm "lemand machtigen" verschijnt.

- Voer in dit scherm de volgende 4 acties uit die met rode pijlen aangegeven staan:

1. Klik op het tabblad "Zoek nieuwe relatie".

2. Kies voor "Bedrijf, samenwerkingsverband, eenmanszaak".

3. Vul in de witte zoekbalk het woord 'akkerweb' in.

4. Klik op 'Zoek'.

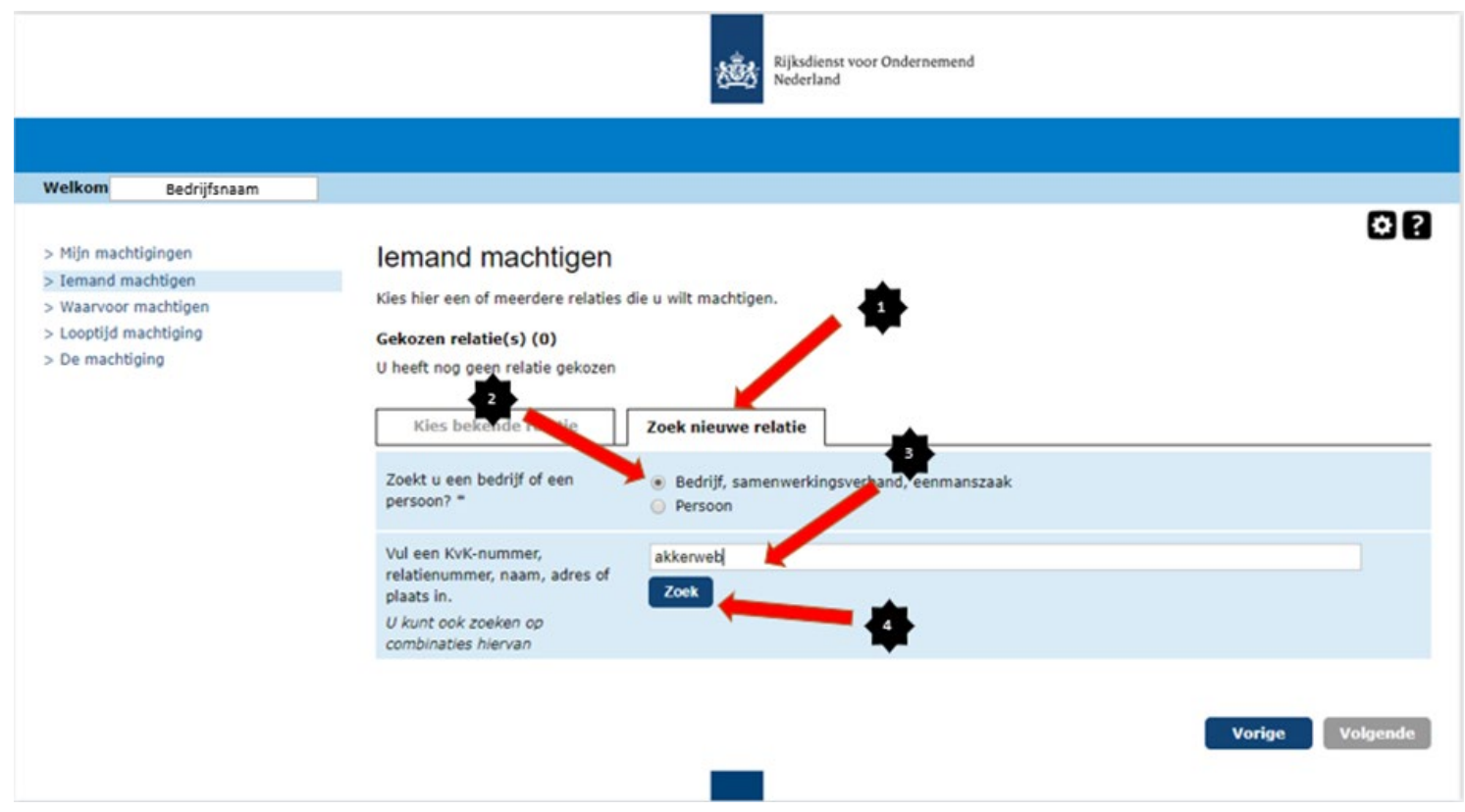


Het scherm "Gekozen relatie(s)" verschijnt.

- In het scherm "Gekozen relatie(s)" komt één resultaat naar voren (Akkerweb).

- Klik op 'Volgende'.

Gekozen relatie(s) (1)

- Stichting Akkerweb, KVK 66703980, Landgoedlaan 20, 7325AW APELDOORN

\begin{tabular}{|l|l|}
\hline \multicolumn{1}{|c|}{ Kies bekende relatie } & Zoek nieuwe relatie \\
\hline $\begin{array}{l}\text { Zoekt u een bedrijf of een } \\
\text { persoon? * }\end{array}$ & $\begin{array}{l}\text { - Bedrijf, samenwerkingsverband, eenmanszaak } \\
\text { Persoon }\end{array}$ \\
$\begin{array}{l}\text { Vul een KvK-nummer, } \\
\text { relatienummer, naam, adres of } \\
\text { plaats in. } \\
\begin{array}{l}\text { U kunt ook zoeken op } \\
\text { combinaties hiervan }\end{array}\end{array}$ \\
\hline
\end{tabular}

\section{Zoekresultaten (1)}

Kies een relatie uit de lijst

+ Stichting Akkerweb, KvK 66703980, Landgoedlaan 20, 7325AW APELDOORN

Het scherm "Gekozen onderwerpen" verschijnt.

- Klik alle drie + icoontjes aan in het scherm "Gekozen onderwerpen".

- Het beeld op het scherm verandert en geeft alle gekozen onderwerpen weer.

- Klik op 'Volgende'.

Gekozen onderwerpen (4)

- Alle diensten in Mijn machtigingen(volmacht)

- Melkveefosfaatreferentie

- Perceelsgegevens leveren aan

- VDM gegevens leveren aan

Eerder gekozen onderwerp Kies nieuw onderwerp

Het scherm "Looptijd machtiging' verschijnt.

- Geef de 'Begindatum' op. Dit is een verplicht veld.

- Een einddatum is vrij in te vullen.

- Klik op 'Volgende'.

\section{Looptijd machtiging}

Geef hier de begindatum en eventueel een einddatum van de machtiging aan. Tekst in het veld Toelichting ziet u later terug bij het bekijken van de machtiging.

Begindatum =
Einddatum
Toelichting


Het scherm "De machtiging" verschijnt. Hierin wordt bevestigt dat u Stichting Akkerweb machtigt voor het gebruik van de gegevens van RVO

- Vink het vakje aan bij “Ja, ik ga akkoord met deze machtiging”.

- Klik op 'Verstuur'.

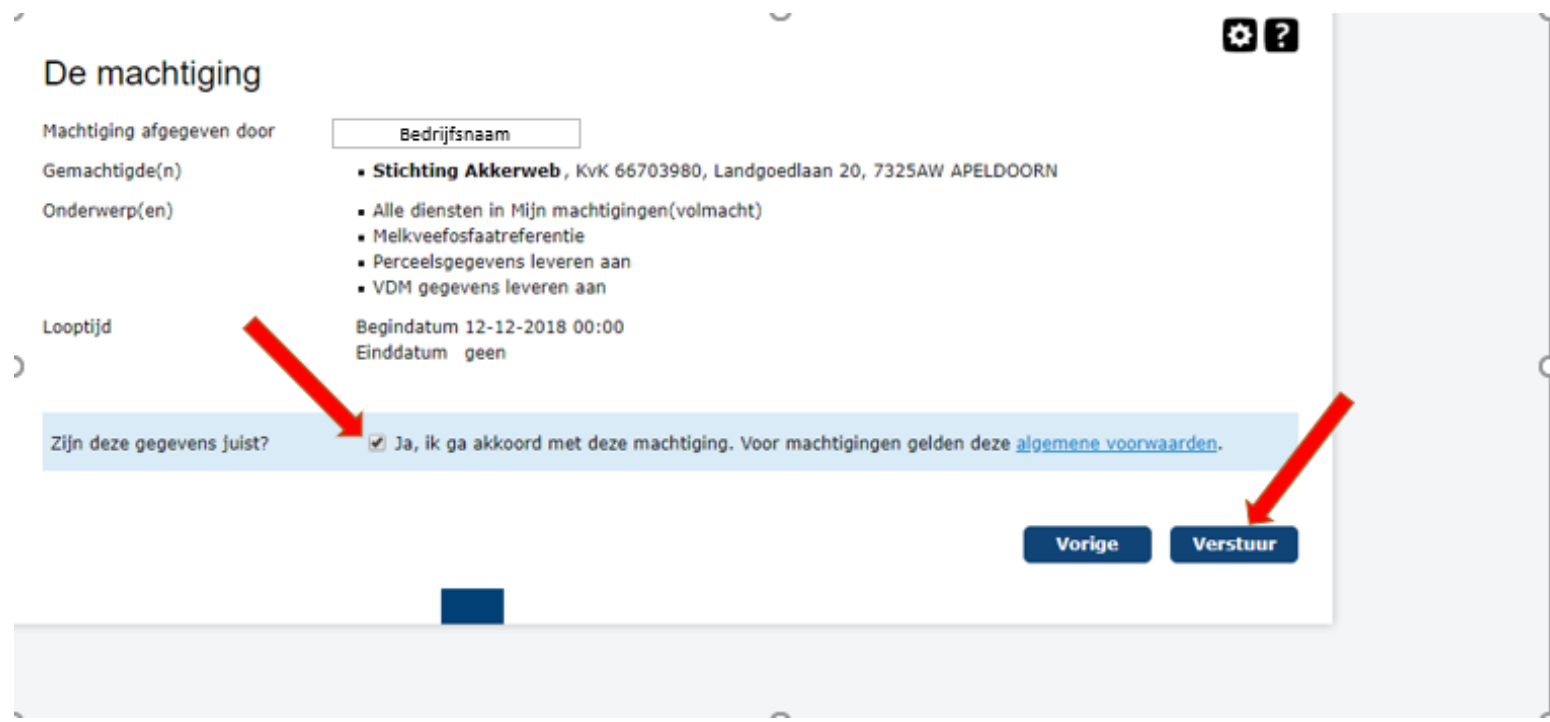

Het scherm "Bevestiging" verschijnt.

- Klik op "Sluiten en naar Mijn machtigingen".

- Het scherm met uw dossier verschijnt. U heeft deze procedure succesvol afgerond.

\section{Bevestiging}

Iemand machtigen

Wij hebben uw machtiging geregistreerd. $U$ kunt uw machtigingen bekijken en wijzigen via Mijn machtigingen.

\subsection{Account aanmaken voor Akkerweb}

Om de perceelsgegevens makkelijk en snel in de BedrijfsWaterWijzer te importeren, is een account nodig bij Akkerweb. In deze paragraaf wordt beschreven hoe dit account aangemaakt kan worden. Voor deze handleiding is het account bij Akkerweb aangemaakt in een testomgeving van Akkerweb. Voordat het account in Akkerweb aangemaakt wordt, moet eerst de procedure beschreven in paragraaf 2.1 (Procedure machtiging RVO voor Akkerweb) doorlopen worden.

\subsubsection{Aanmelden bij Akkerweb testomgeving}

- Ga naar uw webbrowser en type de volgende link in: http://awtest.nl. U komt dan terecht op een pagina die er als volgt uitziet:

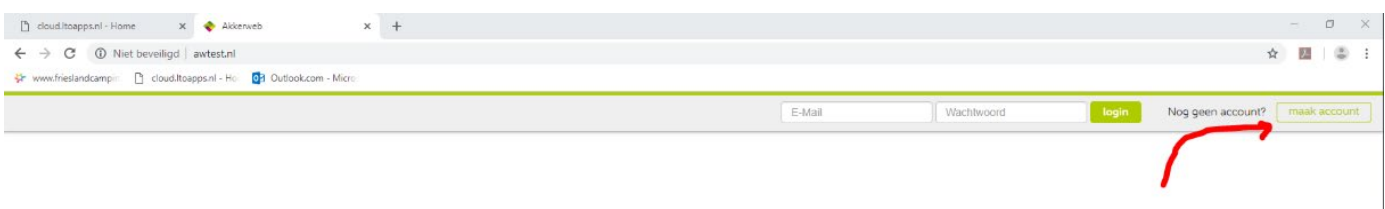


- Klik aan de rechterkant van het scherm op: maak account (zie rode pijl).

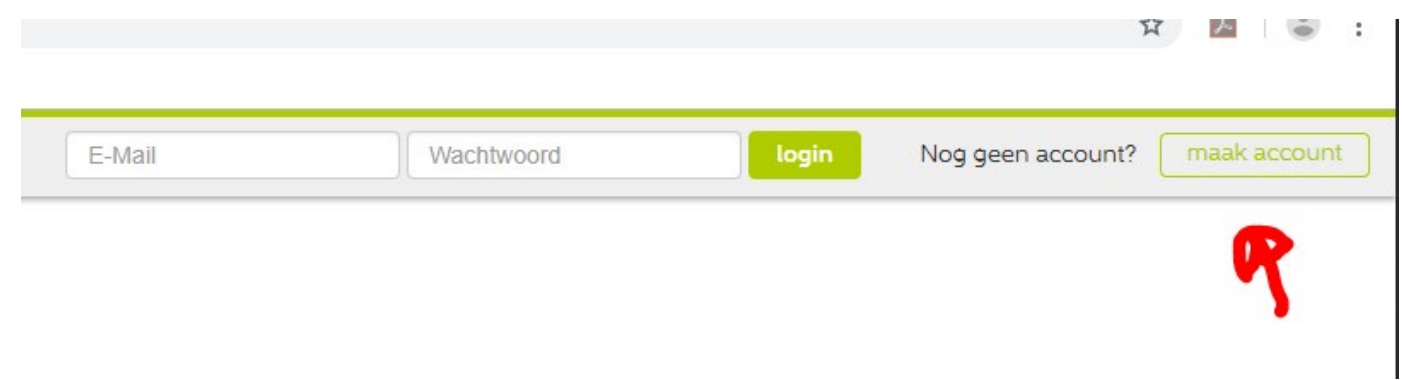

Het scherm "Een Akkerweb account maken" verschijnt.

- Vul deze pagina als volgt in:

1. Vul uw huidige emailadres in

2. Maak een wachtwoord aan, bij voorkeur via de volgende combinatie:

UwAchternaam\#Huisnummer_BWW2019, dus bijvoorbeeld Jansen\#2_BWW2019, maar u mag ook zelf wat verzinnen. Gebruik in ieder geval geen wachtwoord dat $u$ al ergens gebruikt in combinatie met uw email.

3. Herhaal uw wachtwoord.

4. Geef uw naam op.

5. Vink het hokje aan nadat u de voorwaarden hebt doorgelezen.

6. Klik op 'Maak mijn account aan'.

\section{Een Akkerweb account maken}

Heeft u al een Akkerweb account? Dan kunt u hier inloggen.

Uw huidige e-mailadres

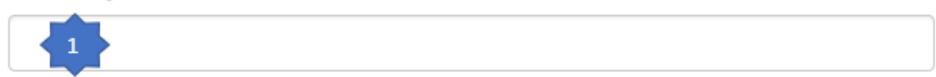

Kies een wachtwoord

2

Wachtwoord nogmaals typen

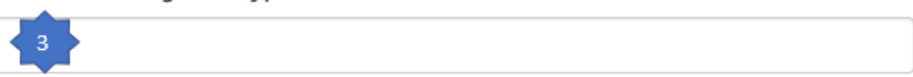

Uw naam

Ik ga akkoord met de voorwaarden. Klik hier om de voorwaarden als PDF te

downloaden

Maak mijn account aan

De volgende melding wordt weergegeven:

- Ga naar uw e-mail. Daar vindt u de mail van Akkerweb om het emailadres te bevestigen.

\section{Uw account is aangemaakt}

Welkom bij Akkerweb, uw acount is met succes aangemaakt en we hebben een email gestuurd naar bbassa@projectenltonoord.nl om dit te bevestigen. Voordat u uw account kunt gebruiken dient $u$ op de link in de e-mail te klikken om uw e-mailadres te verifiëren. 
- Klik op de paars/roze knop met tekst e-mailadres bevestigen.

\section{Beste Akkerweb-gebruiker}

Nog één stap voordat u van Akkerweb gebruik kunt maken.

Wij vragen u uw e-mailadres te bevestigen. Klik op de button hieronder:

\section{a-mailadres bevestigen}

Werkt de button niet? Klik dan op deze link of kopieer de link in uw internetbrowser: http://accounts.awtest.nI/NalidateEmail? continue=http $\% 3 a \% 2 f \% 2$ fawtest.nl\%2fLogin $\% 3$ fredirect uri $\% 3$ dhttp $\% 253 a \% 252$ f $\% 252$ fawtest.nl $\% 252$ fShell $\% 253$ fra $\%$ 253dtrue \&code $=969 \mathrm{e} 6070 \mathrm{f} 4 \mathrm{be} 490 \mathrm{e} 96 \mathrm{c} 9 \mathrm{fd} 74628 \mathrm{c} 2 \mathrm{~b} 69$

De algemene voorwaarden kunt u hier downloaden als PDF.

Met vriendelijke groet,

Het team van Akkerweb

- Het scherm met de tekst "E-mailadres geverifieerd" verschijnt.

- Klik op 'Ga verder'. De aanmelding is gereed om in het scherm "Aanmelden" in te loggen.

\section{akkerweb}

\section{E-mailadres geverifieerd \\ Uw e-mailadres $\quad$ uw emailadres is geverifieerd

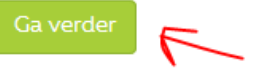

Het aanmeldscherm verschijnt.

- Vul in het aanmeldscherm uw e-mail en uw eerder opgegeven wachtwoord in om aan te melden.

akkerweb

\section{Aanmelden}

E-mail

\section{Aanmelden}

Heeft u nog geen Akkerweb account? Vraag er een aan. Wachtwoord vergeten?

- Onderstaand openingsscherm verschijnt. U weet nu zeker dat uw aanmelding goed doorlopen is.

akkerweb

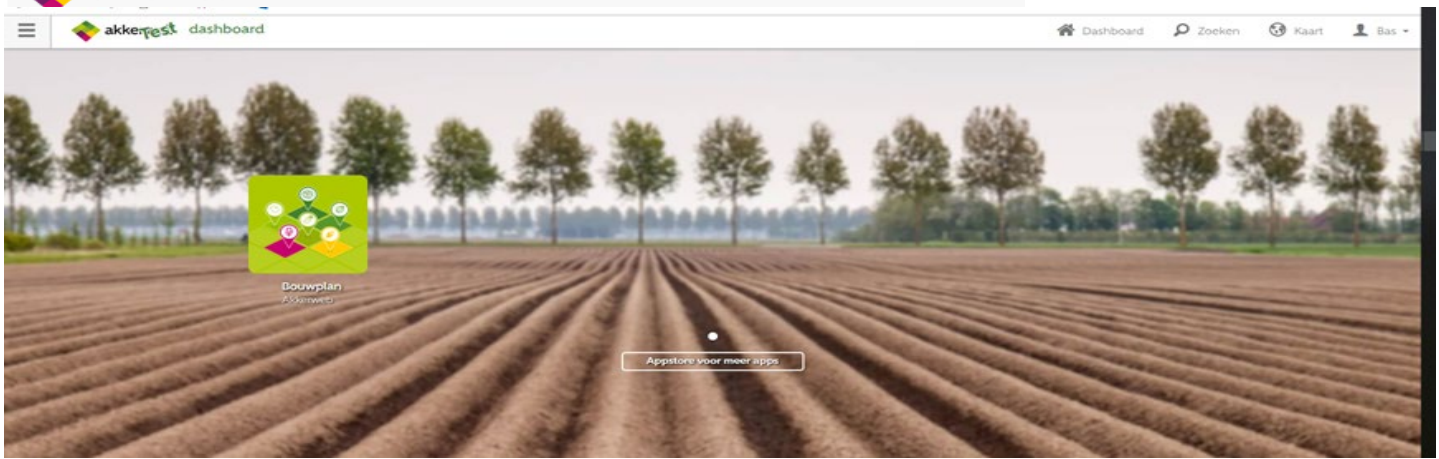




\subsubsection{Ophalen van perceelsgegevens uit RVO}

- Klik op het groene icoon met 'Bouwplan; Akkerweb'.

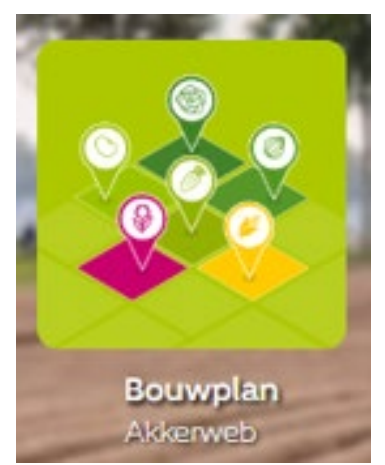

Het scherm "akkerTest; bouwplan" verschijnt.

- Klik op 'Nieuw bouwplan'. Het scherm "akkerTest; bouwplan", "Leeg bouwplan" verschijnt om een jaartal te kiezen.

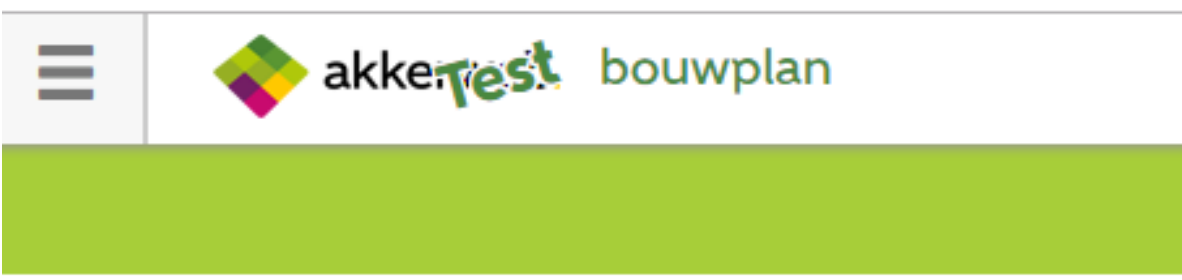

Geen bouwplan gevonden..

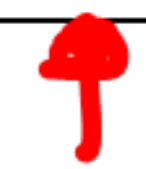

Het huidige jaar staat groot in het midden aan de bovenkant.

- Beweeg met de muis naar 2019 totdat de tekst 'Vorig jaar' zichtbaar wordt.

- Klik op 'Vorig jaar'. Het jaartal van vorig jaar verschijnt in het midden. Klik vervolgens op 'Import'.

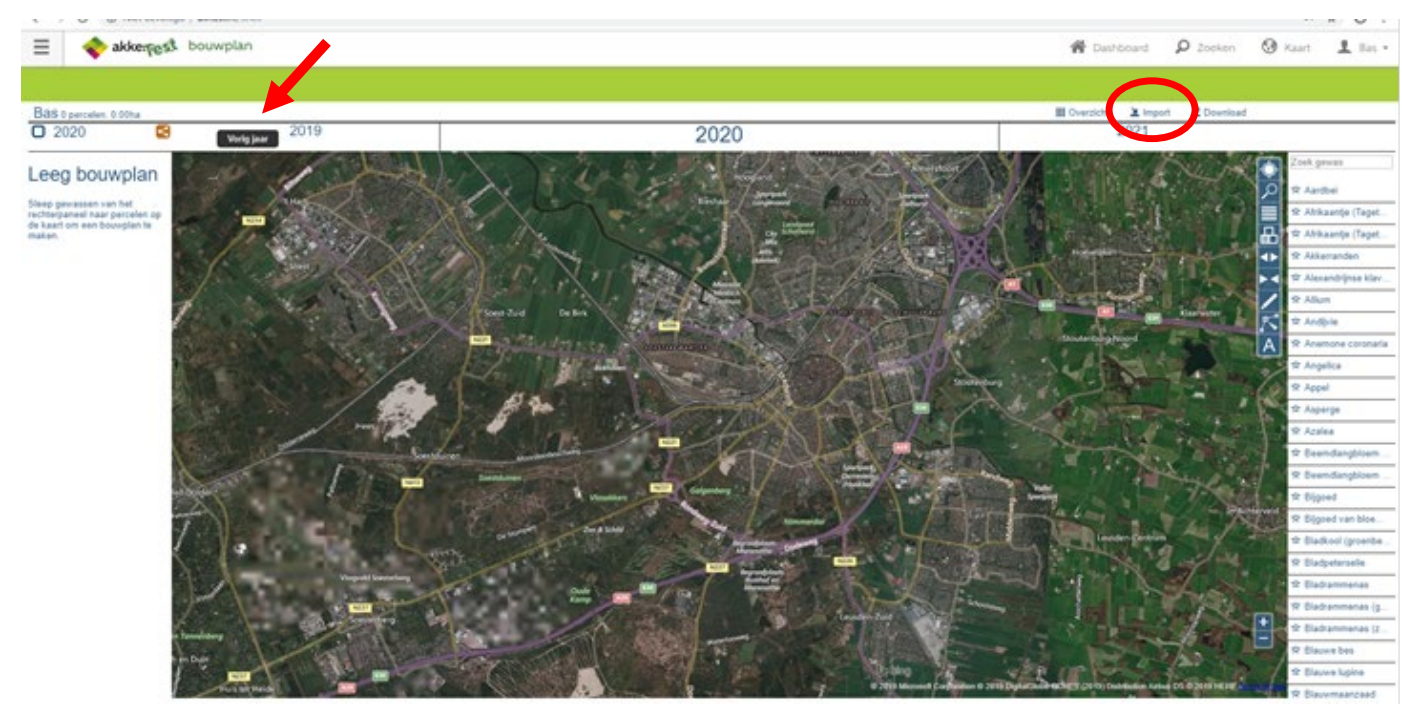

Het scherm "Importeer gewaspercelen" verschijnt. 
- Klik onder "Selecteer bron:” op het pulldown menu 'Kies' en selecteer 'RVO'.

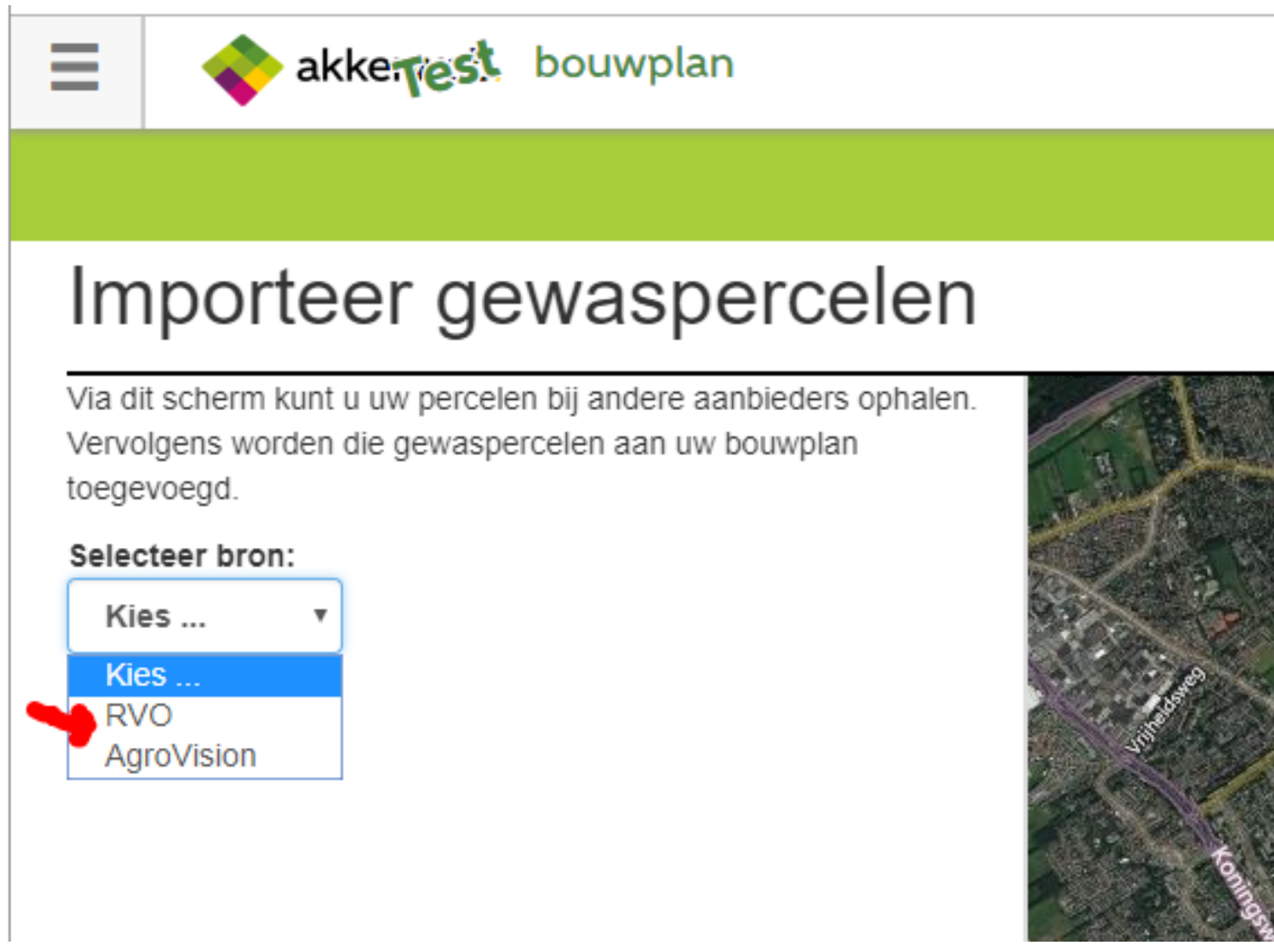

Een scherm verschijnt om meerdere opties te kunnen selecteren.

- Vul uw KvK nummer in.

- Selecteer het jaar waarover de gegevens opgehaald moeten worden (in dit voorbeeld 2018).

- Klik op 'Ophalen'. Het ophalen van de gegevens kan even duren.

Selecteer bron:

KvK. nr.:

Kvk. nr.

Selecteer jaar:

2018 V

צ Ophalen

Het scherm met "Opgehaalde percelen: $x / x x$ " verschijnt.

- Klik onder "Selecteer jaar:" op 'Kies' en selecteer het jaar waarover de gegevens opgehaald moeten worden (in dit voorbeeld 2018).

- Klik op 'Importeer'. Afhankelijk van het aantal percelen kan dit even duren 


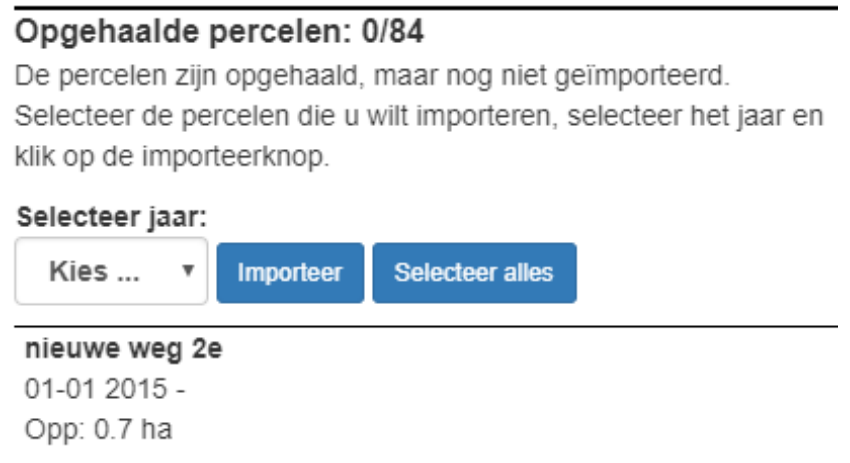

Een scherm met de toelichting "Het importeren is wel of niet gelukt verschijnt.

Als het importeren wel is gelukt:

- Klik in het groen gearceerde deel met tekst op 'Klik hier' (zie rode pijl in onderstaande afbeelding). Een scherm wordt geopend met allerlei gegevens over de percelen.

\section{Opgehaalde percelen: $84 / 84$ \\ De percelen zijn opgehaald, maar nog niet geïmporteerd. \\ Selecteer de percelen die u wilt importeren, selecteer het jaar en klik op de importeerknop.}

\section{Selecteer jaar:}

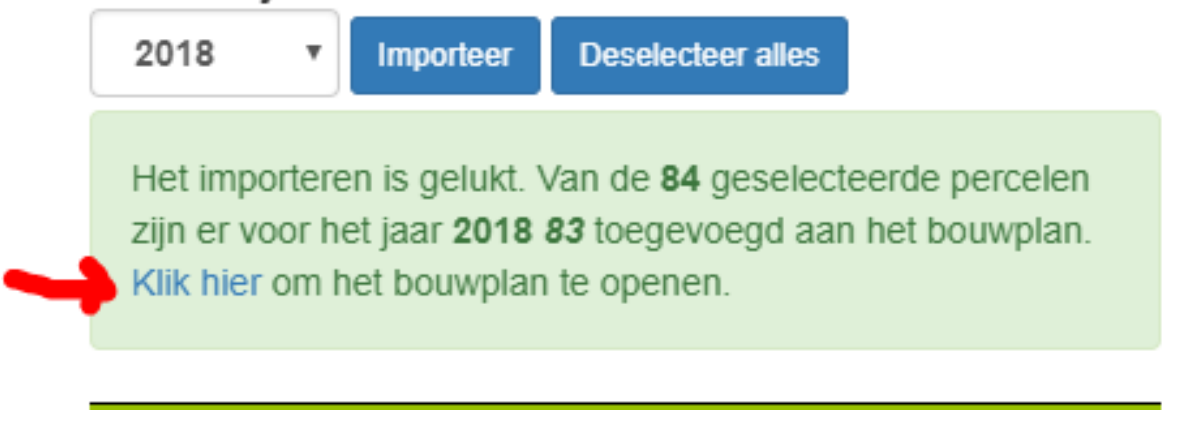

Als het importeren niet is gelukt dan zijn de volgende opties mogelijk:

- Check in Akkerweb of het bouwplan daar wel klopt: met name de begin en einddatum van een teelt (via het potloodje in de percelenlijst van Akkerweb).

- Als de gegevens tussen RVO en Akkerweb niet consistent zijn: leeg uw bouwplan in Akkerweb en importeer dan vanuit Akkerweb de RVO perceelgegevens opnieuw in uw bouwplan. Gebruik dit bouwplan (na controle) in de BedrijfsWaterWijzer.

- Als de gegevens tussen de BedrijfsWaterWijzer en Akkerweb niet consistent zijn: gebruik de perceelsynchronisatie in de BedrijfsWaterWijzer. Selecteer hierbij het jaar voor het gewenste bouwplan.

\subsection{Gegevens KringloopWijzer exporteren voor invoer in BedrijfsWaterWijzer}

Voor de BedrijfsWaterWijzer is een output.xml-bestand van de KringloopWijzer nodig. Dit bestand moet opgevraagd worden bij de Database KringloopWijzer.

- Ga naar www.mijnkringloopwijzer.nl en log in met eHerkenning.

- Kies het meest actuele beschikbare jaar.

- Open het tabblad 'Rapportage' en kies KLW Mail opties (onderste regel in dropdown menu). 


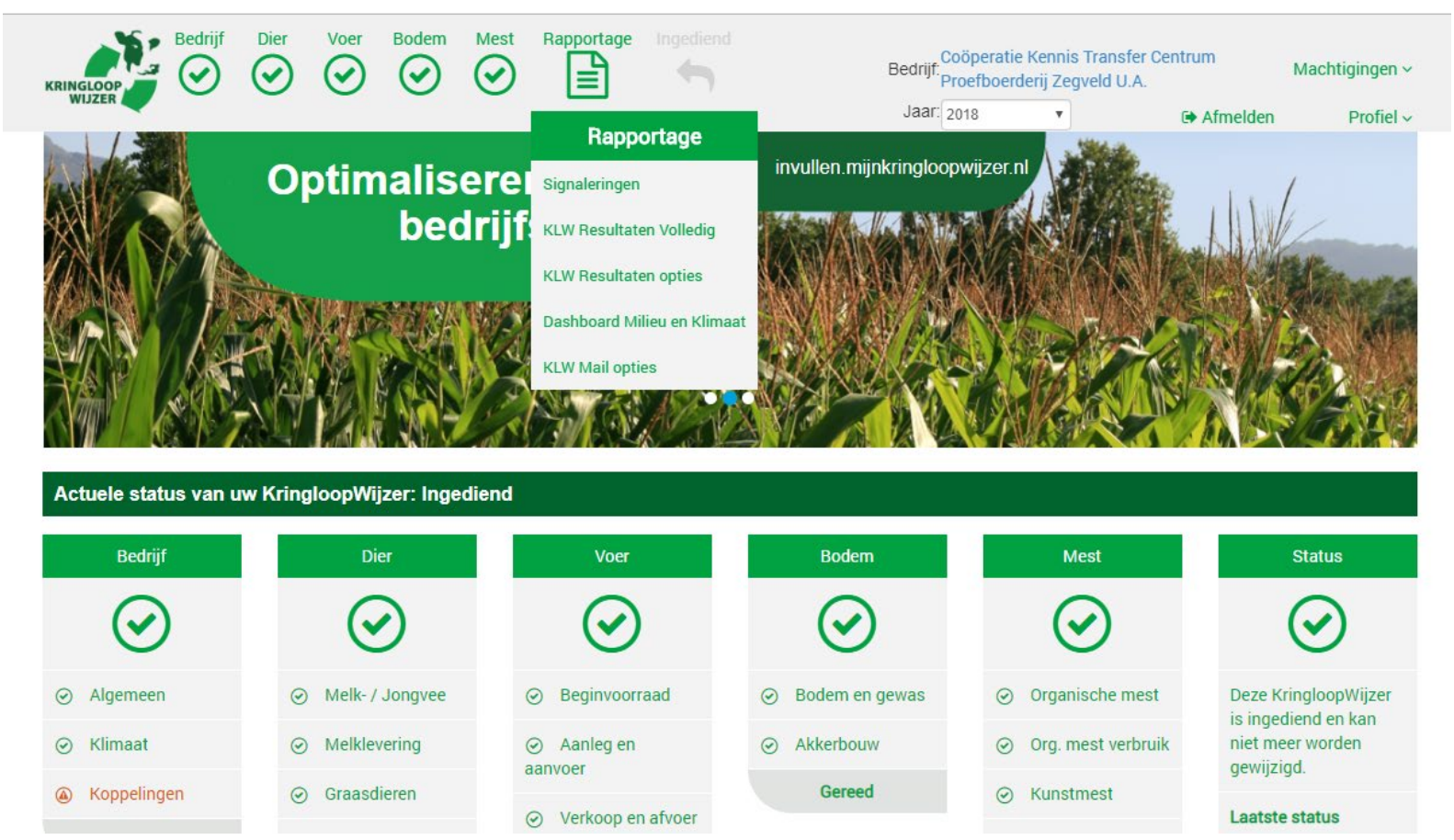

- Selecteer 'output.xml, is een xml-bestand met de resultaten van de rekenmodule van de WUR'.

- Vul 'Naam afzender' in en je eigen Email adres en klik op verzenden.

- Sla vanaf je email account het ouput.xml-bestand op, op je eigen computer (noteer de locatie op de computer waar het bestand is opgeslagen).

Het bestand van de KringloopWijzer is nu klaar om in te lezen in de BedrijfsWaterWijzer.
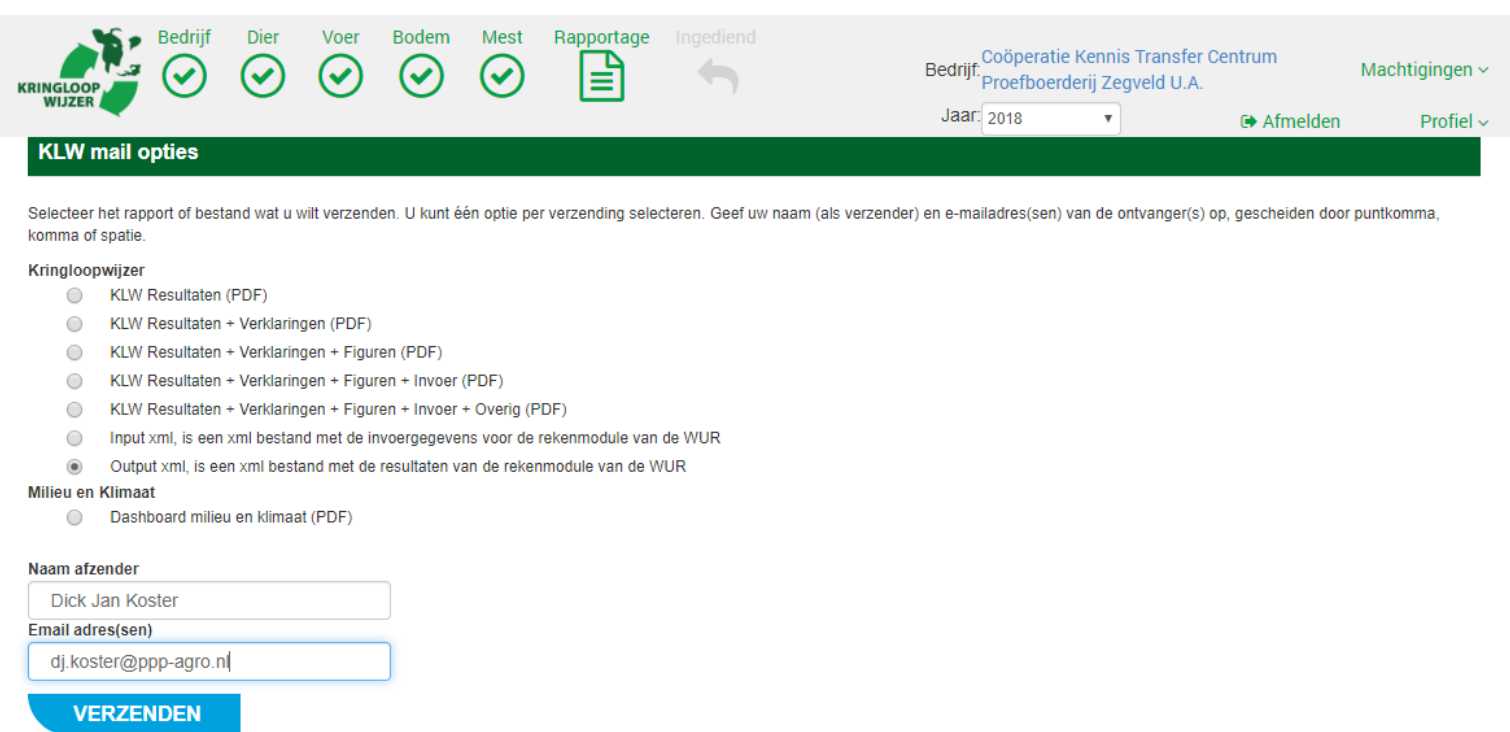


\section{Inloggen via Akkerweb en wisselen van bedrijf binnen de BWW}

\subsection{Inloggen via Akkerweb}

BedrijfsWaterWijzer maakt gebruik van de geografische informatie over percelen die via RVO en Akkerweb beschikbaar zijn. Het inloggen op de BedrijfsWaterWijzer vindt daarom plaats via de externe service van Akkerweb. Voordeel hiervan is dat het in Akkerweb aangemaakte bouwplan direct kan worden ingelezen in de BWW.

- Ga naar de BedrijfsWaterWijzer (https://webapplicaties.wur.nl/Software/BedrijfsWaterWijzer/Home/Index),

- Kies 'Gebruik een externe service om in te loggen' (rechtsboven in het scherm) en klik op 'Akkerweb'.

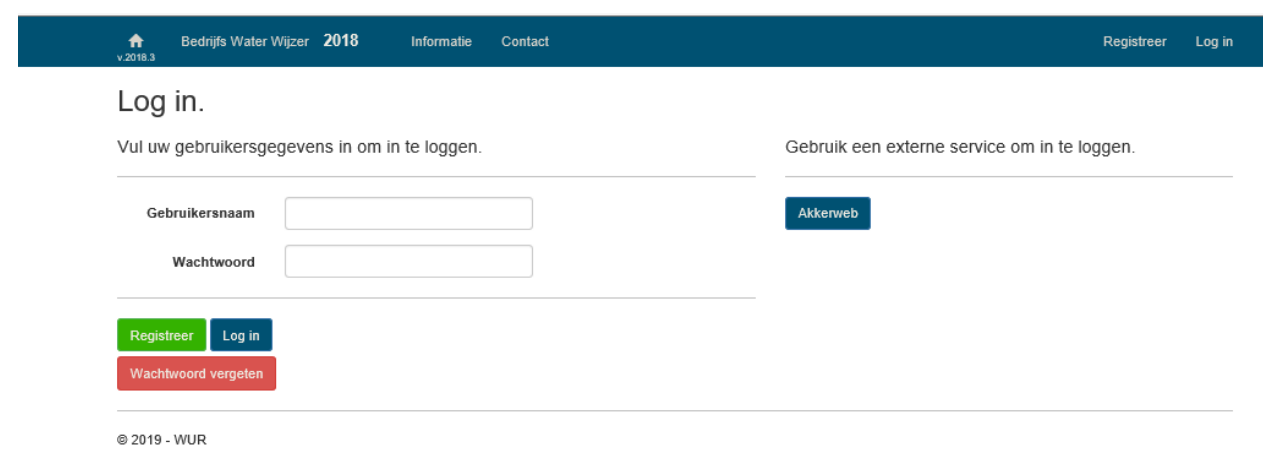

- Log in met mailadres en wachtwoord.

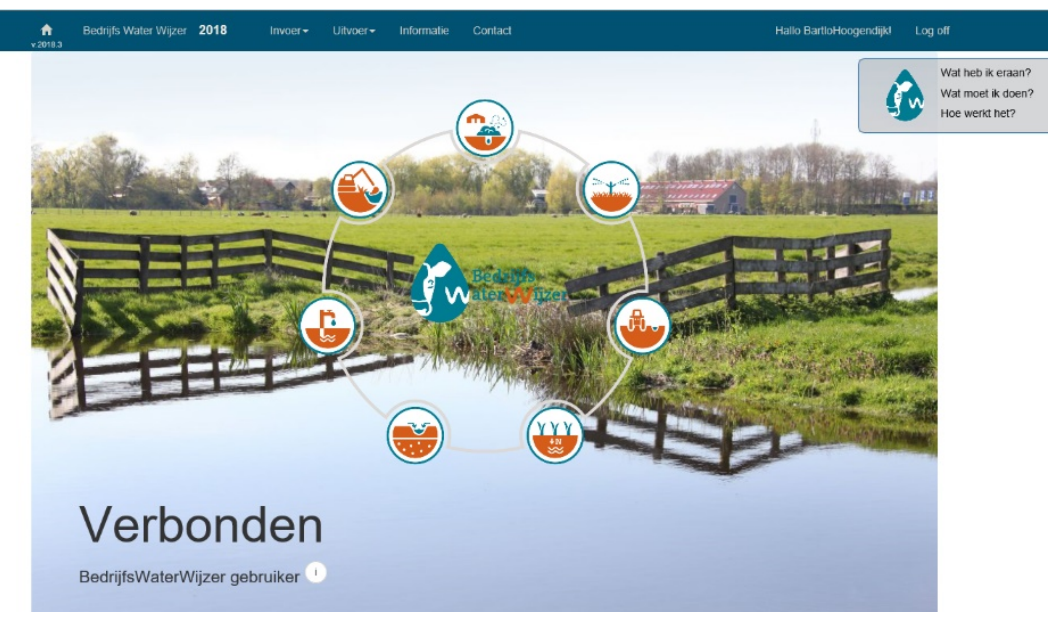

Ga voor het invoeren van de gegevens van het bedrijf naar hoofdstuk 3 van deze handleiding.

\section{2}

\section{Wisselen van bedrijf}

In de BedrijfsWaterWijzer is het niet mogelijk om zonder tussenstap van bedrijf (account) te wisselen. Wordt nu een BedrijfsWaterWijzer sessie van een bedrijf gestopt, dan wordt bij hernieuwd aanloggen via de knop Akkerweb, het laatst gebruikte bedrijf (account) automatisch opgestart. Als u zich onder een andere bedrijf (account) wilt aanmelden, dan dient in de webbrowser op de gebruikte computer de geschiedenis over de BedrijfsWaterWijzer verwijderd te worden. Hieronder is voor de drie meest gangbare webbrowsers (Internet Explorer, Google Chrome en Apple Safari) de instructie opgenomen:

- Stop de sessie van de BedrijfsWaterWijzer,

- Instructie voor Internet Explorer (alles verwijderen). Deze instructie beschrijft hoe alle geschiedenis verwijderd kan worden: 
- Start de webbrowser Internet Explorer

- Klik rechtsboven in het scherm op 'Extra'

- Klik op 'Beveiliging'

- Selecteer vervolgens 'Browsegeschiedenis verwijderen'

- Vink aan welke items van de geschiedenis verwijderd moeten worden

- Instructie voor Google Chrome (alles verwijderen). Deze instructie beschrijt hoe alle geschiedenis verwijderd kan worden:

- Open Chrome op de computer.

- Klik rechtsboven op 'Meer' :

- Klik op 'Geschiedenis' en in volgende menu nogmaals op 'Geschiedenis'.

- Klik aan de linkerkant op 'Browsegegevens wissen'. Er wordt een vak weergegeven.

- Selecteer in het dropdown menu welk gedeelte van de geschiedenis verwijderd moet worden. Als alles gewist kan worden, selecteer 'Alles'.

- Vink de selectievakjes aan van de gegevens die in Chrome gewist kunnen worden (waaronder 'browsegeschiedenis').

- Klik op 'Gegevens wissen'.

- Instructie voor Google Chrome; een item verwijderen. Deze instructie beschrijft hoe een bepaald deel van de geschiedenis verwijderd kan worden:

- Open Chrome op de computer.

- Klik rechtsboven op 'Meer'

- Klik op 'Geschiedenis' en in volgende menu nogmaals op 'Geschiedenis'.

- Vink het selectievakje aan naast elk item dat verwijderd moet worden uit de geschiedenis.

- Klik rechtsboven op 'Verwijderen'.

- Bevestig de actie door op 'Verwijderen' te klikken.

- Instructie voor Apple Safari:

- Open programma Safari ( ) op de Mac.

- Kies in de menubalk bovenaan 'Geschiedenis'

- Kies 'Wis geschiedenis' en klik vervolgens op het venstermenu.

- Geef aan tot wanneer de geschiedenis gewist moet worden.

- Sluit de geïnstalleerde webbrowser af.

- Start de geïnstalleerde webbrowser opnieuw op.

- Volg de stappen in Par. 2.1 voor het opnieuw starten van de BedrijfsWaterWijzer wanneer met een nieuw bedrijf moet worden begonnen. 


\section{Invoer van gegevens binnen BWW}

In dit hoofdstuk wordt beschreven hoe de gegevens van een nieuw bedriff ingevoerd moeten worden c.q. hoe gegevens gewijzigd kunnen worden nadat het programma BedrijfsWaterWijzer is opgestart. Ook komt de archief functie aan de orde.

\subsection{Invoer bedrijf}

- Klik op Nieuw Bedrijf.

- Vul de gevraagde gegevens in.

- De gegevens bij ' $\mathrm{N}$ bodemoverschot Gras' en 'N bodemoverschot Maïs' worden geïmporteerd en hoeven dus niet ingevuld te worden.

- Klik op 'Bewaar'.

Nieuw

Bedrijf

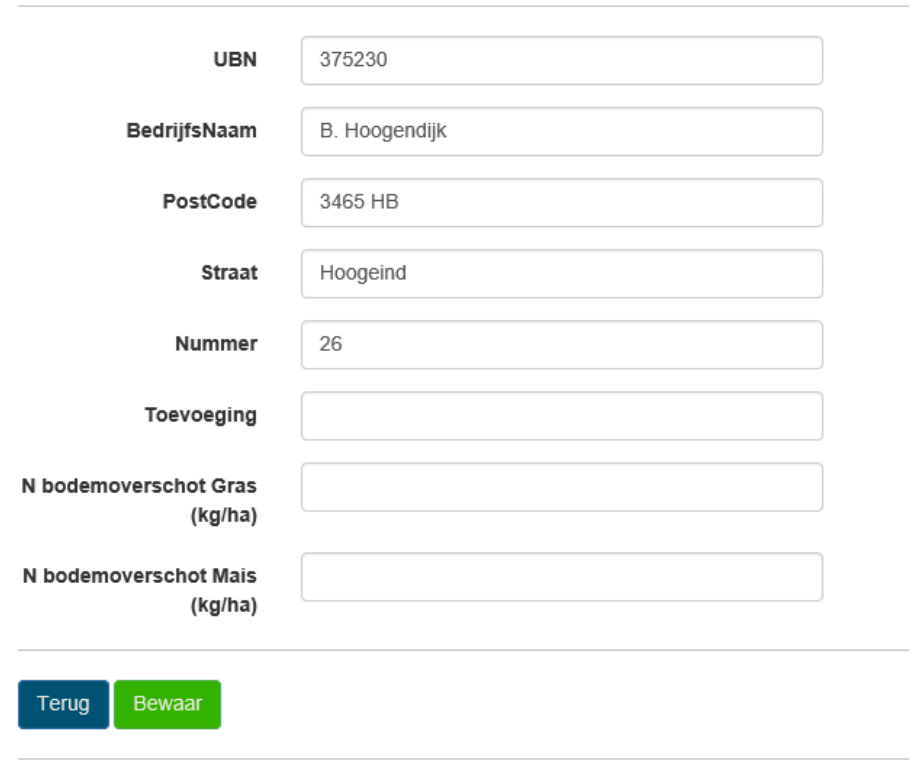

(c) 2019 - WUR

Het bedrijf is nu opgenomen in de BedrijfsWaterWijzer.

Nadat het bedrijf is toegevoegd verschijnt het volgende scherm:

A Bedrijs Water Wijzer 2018 Invoerv Uitvoerv Informatie contact

\section{Adres en Bedrijfscode}

In dit onderdeel worden algemene bedrijfsgegevens geregistreerd. Druk op de knop "Nieuw Bedrijf" om dit te starten. Een gebruiker kan dus meerdere bedrijven hebben. Eenmaal aangemaakte bedrijven worden weergegeven in de lijst. De gegevens van deze bedrijven kunt $u$

altijd wijzigen. Ook is het mogelijk om gegevens van de uitvoer van de Kringloopwijzer in te

lezen via een KLW uitvoer xml-bestand. 
- Kies voor 'Lees KLW-cijfers'.

- Importeer het KLW-uitvoerbestand "output.xml" vanaf de computer. Blader hiervoor naar de locatie op de harde schijf waar het KLW output.xml-bestand is opgeslagen.

- Selecteer het output.xml bestand.

- Klik op 'Lees Bestand'.

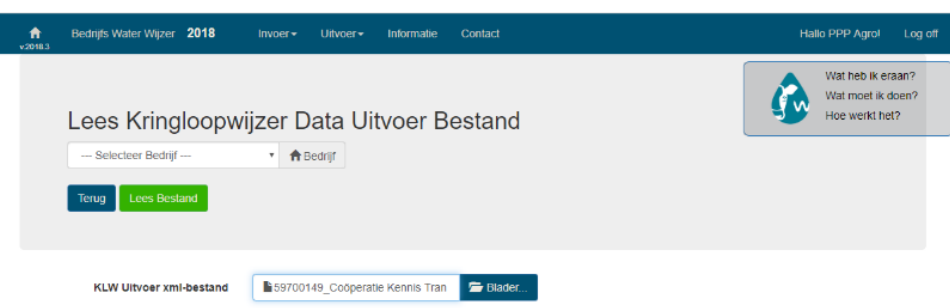

O2019-Wur

- Na invoeren van de KLW Data verschijnt het volgende scherm. Controleer of de data kloppen. Mochten KLW resultaten niet overeenkomen met uw bedrijfsadministratie dan dient de invoer bij de KLW gewijzigd te worden.

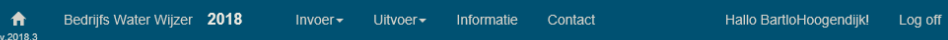

Cijfers KringloopWijzer voor bedrijf Hoogendijk

Terug

\begin{tabular}{|c|c|c|c|c|c|c|c|c|c|}
\hline \multicolumn{2}{|l|}{ N-Bodemoverschot Gras } & $343 \mathrm{~kg}$ & \multicolumn{2}{|l|}{ kg N/ha } & \multicolumn{2}{|c|}{ N-Bodemoverschot Mais } & & 0 & $\mathrm{~kg} \mathrm{~N} / \mathrm{ha}$ \\
\hline \multicolumn{2}{|l|}{ P-Bodemoverschot Gras } & 18 & \multicolumn{2}{|c|}{$\mathrm{kg} \mathrm{P}_{2} \mathrm{O}_{5}$ /ha } & \multicolumn{2}{|c|}{ P-Bodemoverschot Mais } & & 0 & $\mathrm{~kg} \mathrm{P}_{2} \mathrm{O}_{5}$ / ha \\
\hline \multirow{2}{*}{\multicolumn{2}{|c|}{$\begin{array}{l}\text { N-opbrengst Gras } \\
\text { N-bemesting Totaal Gras }\end{array}$}} & 235 & \multicolumn{2}{|l|}{$\mathrm{kg} \mathrm{N} /$ ha } & \multirow{2}{*}{\multicolumn{2}{|c|}{$\begin{array}{l}\text { Opbrengst Mais } \\
\text { N-bemesting Totaal Mais }\end{array}$}} & & 0 & kg N/ha \\
\hline & & $343.46 \mathrm{~kg}$ & $\mathrm{~kg} N / h a$ & & & & & 0 & $\mathrm{~kg} \mathrm{~N} / \mathrm{ha}$ \\
\hline \multicolumn{2}{|l|}{ Oppervlak Productiegras } & $38.33 \mathrm{~h}$ & \multicolumn{2}{|l|}{ ha } & \multirow{2}{*}{\multicolumn{2}{|c|}{$\begin{array}{l}\text { Oppervlak Beheergras } \\
\text { P-Bodemoverschot Akker }\end{array}$}} & & 16.55 & ha \\
\hline Totaaloppervlak Gras & & $54.88 \mathrm{~h}$ & ha & & & & & 0 & $\mathrm{~kg} \mathrm{P}_{2} \mathrm{O}_{5}$ /ha \\
\hline & Produ & tie gras & Behe & gras & Akker & & Mais & & \\
\hline $\mathrm{N}$-bemesting & 446 & kg N/ha & 106 & kg N/ha & & & & & \\
\hline P-bemesting & 102 & $\mathrm{~kg}_{2} \mathrm{O}_{5} /$ ha & 31 & $\mathrm{~kg} \mathrm{P}_{2} \mathrm{O}_{5}$ ha & 0 & $\mathrm{~kg}_{\mathrm{P}}^{2} \mathrm{O}_{5} / \mathrm{ha}$ & 0 & $\mathrm{~kg} \mathrm{P}_{2}$ & $\mathrm{2}_{5} / \mathrm{ha}$ \\
\hline Dlerluke mest & 65 & ton $/$ ha & 8 & ton /na & & & & & \\
\hline Dierlijke mest & 244 & kg N/ha & 94 & kg N/ha & 0 & kg N/ha & 0 & $\mathrm{~kg} \mathrm{~N} /$ & \\
\hline Dierlijke mest & 80 & $\mathrm{~kg}_{2} \mathrm{O}_{5} /$ ha & 27 & $\mathrm{~kg} \mathrm{P}_{2} \mathrm{O}_{5}$ /ha & 0 & $\mathrm{~kg}_{2} \mathrm{O}_{5} / \mathrm{ha}$ & 0 & $\mathrm{~kg}_{2}$ & $\mathrm{2}_{5} \mathrm{ha}$ \\
\hline Kunstmest & 117 & kg N/na & 0 & $\mathrm{~kg} \mathrm{~N} / \mathrm{ha}$ & 0 & kg N/na & 0 & $\mathrm{~kg} \mathrm{~N} / \mathrm{t}$ & \\
\hline Kunstmest & 0 & $\mathrm{~kg}_{2} \mathrm{O}_{5} /$ ha & 0 & $\mathrm{~kg} \mathrm{P}_{2} \mathrm{O}_{5}$ ha & 0 & $\mathrm{~kg}_{\mathrm{P}} \mathrm{O}_{5} / \mathrm{ha}$ & 0 & $\mathrm{~kg} \mathrm{P}_{2} \mathrm{C}$ & $\mathrm{2}_{5} / \mathrm{ha}$ \\
\hline Weidemest & 86 & $\mathrm{~kg} \mathrm{~N} / \mathrm{ha}$ & 12 & $\mathrm{~kg} \mathrm{~N} / \mathrm{ha}$ & & & & & \\
\hline weldemest & 21 & $\mathrm{~kg}_{2} \mathrm{O}_{5} / \mathrm{ha}$ & 3 & $\mathrm{Kg} \mathrm{P}_{2} \mathrm{O}_{5}$ / ha & & & & & \\
\hline Opbrengst & 80 & $\mathrm{~kg} \mathrm{P}_{2} \mathrm{O}_{5} /$ ha & 21 & $\mathrm{~kg} \mathrm{P}_{2} \mathrm{O}_{5}$ ha & 0 & $\mathrm{~kg}_{2} \mathrm{O}_{5} / \mathrm{ha}$ & 0 & $\mathrm{~kg} \mathrm{P}_{2}$ & $\mathrm{O}_{5} / \mathrm{ha}$ \\
\hline
\end{tabular}

- Als de gegevens juist zijn klik dan op de knop 'Terug' in bovenste grijze balk. Het scherm "Beheer van uw bedrijven" verschijnt.

\section{A Bedrifs Water Wijzer 2019 Invoer v Uitvoer - Informatie Contact}

\section{Beheer van uw bedrijven}

$\mathrm{U}$ beheert hier de lijst van actieve eigen- en voorbeeldbedrijven. Druk op de knop "Nieuw Bedrijf" om dit te starten.

- Gebruik de knop "Bewaar" om een kopie van een bedrijf op te slaan in het archief, het bedrijf blijft in uw actieve lijst.

- Gebruik de knop Archief om een kopie van een eerder opgeslagen bedrijf terug te halen naar de actieve lijst.

- Gebruik de oranje knop "Check" om een uit uw archief teruggehaald bedrijf een nieuwe naam te geven

De gegevens van actieve bedrijven kunt $u$ altijd wijzigen. Ook is het mogelijk om gegevens van de uitvoer van de Kringloopwijzer in te lezen via een KLW uitvoer xml-bestand.

Het getoonde lijstje van bedrijven zijn de bedrijven waarmee u actief werkt. Vaak zal hier maar één bedrijf staan. Maar het is mogelijk om meerdere bedrijven tegelijk te beheren. 


\subsection{Beheren van bedrijven - Archief functie}

Een bedrijfssituatie kan in de loop van de tijd veranderen door bijvoorbeeld aan- of verkoop van grond of wijziging van het management van (een onderdeel van) het bedrijf. Om wat voor reden dan ook kan het wenselijk zijn dat de gegevens, zoals van voor een verandering, bewaard blijven. Het begin van een nieuw boekjaar kan bijvoorbeeld ook een geschikt moment zijn voor het archiveren van de bedrijfssituatie van het afgelopen jaar.

Met de Archief functie wordt een blauwdruk (kopie) van het geselecteerde actieve bedrijf gemaakt. De kopie krijgt een naam en komt onder de knop "Archief" te staan. Er kan in het huidige bedrijf in de BWW doorgewerkt blijven worden. Wijziging van gegevens in het bedrijf waarin wordt doorgewerkt, hebben geen invloed op de gegevens in het kopie van het bedrijf.

Een eerder opgeslagen kopie van de bedrijfssituatie kan worden ingezien door het kopie terug te halen naar de lijst van actieve bedrijven via de knop "Archief". De opgeslagen informatie blijft in het archief bestaan. Om niet in verwarring te komen met het originele actieve bedrijf, wordt verzocht het teruggehaalde kopie bedrijf een nieuwe naam te geven.

\section{Beheer van uw bedrijven}

U beheert hier de lijst van actieve eigen- en voorbeeldbedrijven. Druk op de knop "Nieuw Bedrijf" om dit te starten.

- Gebruik de knop "Bewaar" om een kopie van een bedrijf op te slaan in het archief, het bedrijf blijft in uw actieve lijst.

- Gebruik de knop Archief om een kopie van een eerder opgeslagen bedrijf terug te halen naar de actieve lijst.

- Gebruik de oranje knop "Check" om een uit uw archief teruggehaald bedrijf een nieuwe naam te geven.

De gegevens van actieve bedrijven kunt $u$ altijd wijzigen. Ook is het mogelijk om gegevens van de uitvoer van de Kringloopwijzer in te lezen via een KLW uitvoer xml-bestand.

\section{+ Nieuw Bedrijf $\perp$ Archief \pm Importeer Voorbeeld Bedrijf $\boldsymbol{t}$ Lees KLW-cijfers}

Eigen bedrijven

\begin{tabular}{|c|c|c|c|c|c|c|}
\hline \multirow[t]{2}{*}{ UBN } & \multirow[t]{2}{*}{ Bedrijf } & \multicolumn{5}{|l|}{ Opties } \\
\hline & & wijzig & Toon KLW-cijfers & Bewaar & 息 Verwijder & GeoView \\
\hline & & $/$ wizig & $\downarrow$ Lees KLW-cijfers & Dì Bewaar & 畺 Verwijder & GeoViev \\
\hline
\end{tabular}

Volgende Stap: Invoer Percelen $\rightarrow$

- Klik op ‘国 Bewaar' om een 'kopie' van het originele bedrijf in het archief op te slaan.

- Het scherm "Opslaan Bedrijf” verschijnt.

- Wijzig eventueel de naam van het archiefbestand bij 'NaamArchiefEntry' en klik op 'Save'.

\section{Opslaan Bedrijf}

melkveebedrijf te--

\begin{tabular}{|c|c|c|c|}
\hline NaamArchiefEntry & melk-2020-1 & Terug & Save \\
\hline
\end{tabular}

(ㄷ) 2020 - WUR

- Klik op ' $\downarrow$ Archief' (wat door de bewaaractie is gewijzigd van grijs in donkerblauw). Een pop-up verschijnt met een of meerdere archiefbestanden die zijn gemaakt.

- Klik op de naam van het archiefbestand wat teruggehaald moet worden naar de actieve lijst om te bewerken. 


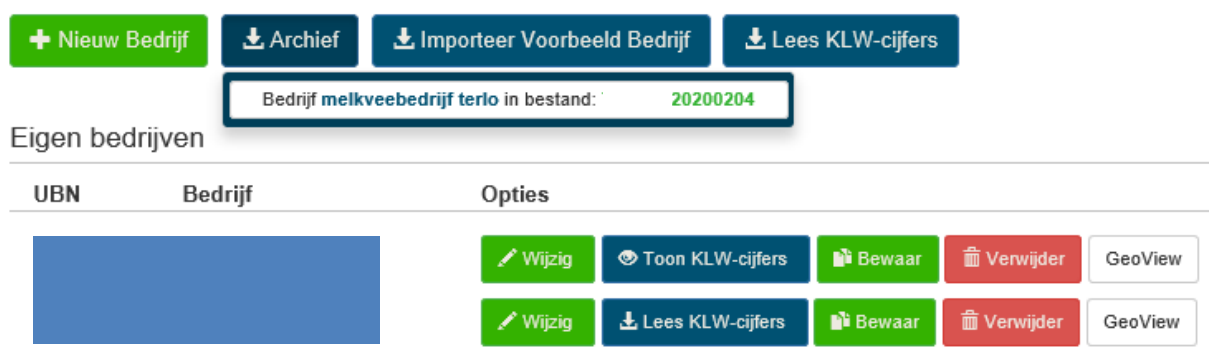

Een overzicht van de actieve lijst van bedrijven verschijnt waarbij achter de naam van de laatst teruggehaalde bedrijven in een oranje tekstbox ' $\theta$ Check' verschijnt.

\section{+ Nieuw Bedrijf \pm Archief $\downarrow$ Importeer Voorbeeld Bedrijf $\downarrow$ Lees KLW-cijfers}

\section{Eigen bedrijven}

\begin{tabular}{|c|c|c|c|c|c|c|}
\hline UBN & Bedrijf & Opties & & & & \\
\hline & & Wijzig & - Toon KLW-cijfers & Dì Bewaar & 角 Vervijder & GeoView \\
\hline & & wijzig & L Lees KLW-ciffers & Dì Bewaar & 兽 Verwijder & GeoView \\
\hline & & Check & (-) Toon KLW-cijfers & Dì Bewaar & 竞 Verwijder & GeoView \\
\hline
\end{tabular}

- Klik $\theta$ op 'Check' om de naam van het kopie bedrijf te wijzigen. Hiermee wordt onderscheid gemaakt tussen het originele bedrijf en het uit het archief opgehaalde bedrijf.

- Het scherm 'Wijzig Bedrijf' verschijnt.

- Wijzig eventueel gegevens en klik op ‘Bewaar”. De optie $\&$ 'Check' veranderd in ' $\&$ Wijzig'.

\section{Wijzig}

Bedrijf

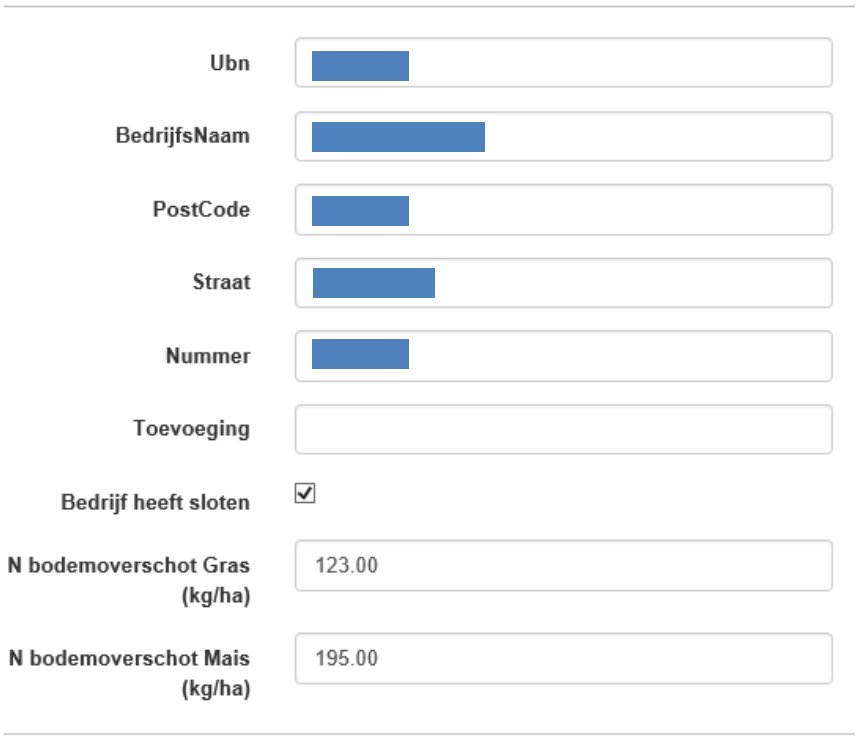

In het opgehaalde kopie bedrijf kunnen nu reeds eerder ingevoerde gegevens van alle modules gewijzigd worden. Het kopie bedrijf en het origineel actieve bedrijf worden behandeld als twee aparte entiteiten. Als gegevens in het één bedrijf worden aangepast, worden deze niet in het andere bedrijf gewijzigd. 
In verband met rekentijd van de BWW, verdient het aanbeveling om de lijst met actieve bedrijven zo kort mogelijk te houden. Uit het archief opgehaalde bedrijven kunnen daarom het beste na bestudering weer worden verwijderd. Ze zijn immers altijd weer uit het archief op te halen.

\subsection{Invoer percelen}

- Selecteer bovenin het scherm het dropdown menu 'Invoer'

- Klik op 'Volgende Stap', 'Invoer percelen'.

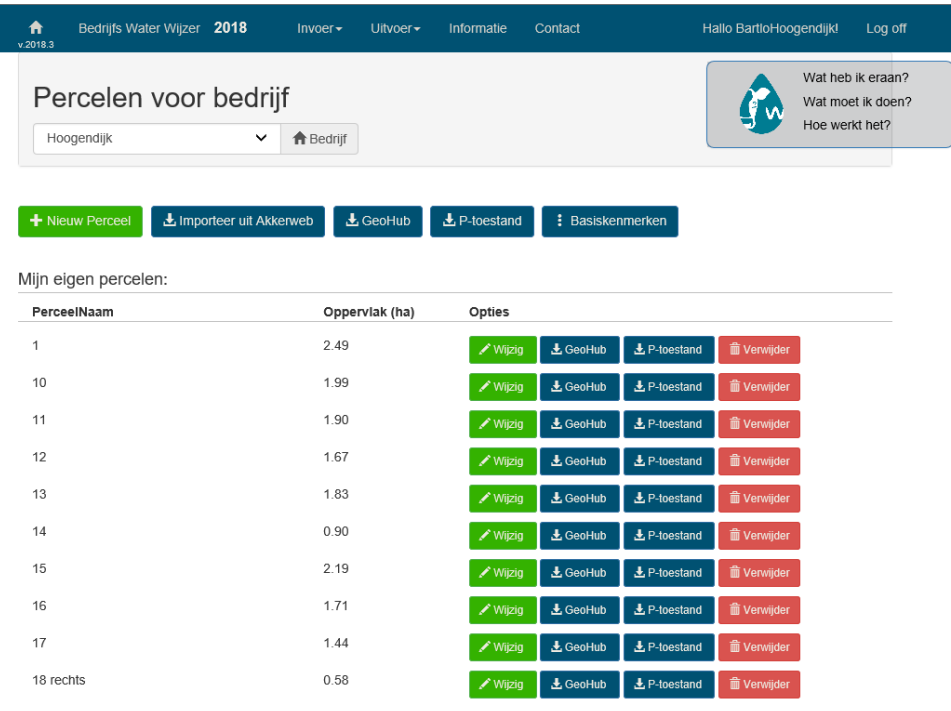

- Klik op» ‘ Importeer uit Akkerweb’.

- Klik vervolgens op $\Perp$ ' GeoHub'. Het scherm “GeoHub import; Bedrijf xxxxx” verschijnt.

- Klik op 'Importeer'. De percelen worden geïmporteerd.

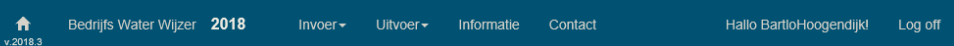

GeoHub import

Bedrij Hoogendijk

De meest recente GeoHub gegevens worden voor al uw percelen van bedijij Hoogendijk opgenaald.
U kunt daarna de gegenens gontroleren, wizigoen al goedkeuren voor elk van deze percelen

Terug

(๑) 2019 - WUR

- Klik na de import 'GeoHub' op 'Terug'.

- Klik in het scherm "Percelen voor bedrijf” op “ $\downarrow$ P-toestand'. Het scherm "P-toestand import; Bedrijf xxxxx" verschijnt.

- Klik op 'Importeer P-toestand', de bestaande informatie wordt geïmporteerd en bij de perceelsinformatie gevoegd.

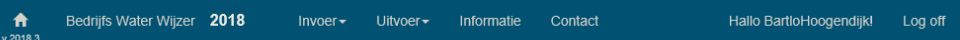

\section{P-toestand import}

Bedrijf Hoogendijk

De meest recente gegevens voor de P-toestand vorden voor all uw percelen van bedrijt Hoogendijk opgehaald.
U kunt daarna de gegevens controleren, wizizigen en goedkeuren voor elk van deze percelen.

Let op: Omdat uw percelen worden opgezocht in de RVO lijst met meer dan 800.000 percelen, kan het ophalen wel 10 seconden per perceel duren-

- Klik na de import P-toestand op 'Terug'. 
- Klik in het scherm "Percelen voor bedrijf" op ': Basiskenmerken'. Het scherm "Bewerk Basiskenmerken voor Percelen" verschijnt.

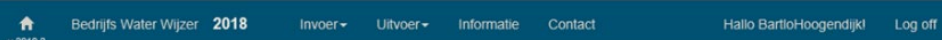

Bewerk Basiskenmerken voor Percelen

Hoogenalik $\quad \sim$ A Beeditit

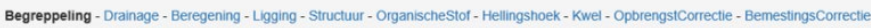

$<>$ Bewaar

Percelen Begreppeling? Percelen Samen

- Ja $\bigcirc$ Nee

- Ja O Nee

- Ja O Nee

- Ja O Nee

- Ja O Nee

- Ja O Nee

- Ja O Nee

- Ja O Nee

- Ja O Nee

- Ja O Nee

- Ja O Nee

- Ja $\bigcirc$ Nee

- Ja O Nee

- Ja O Nee

- Ja O Nee

- Ja O Nee

- Gebruik de '<' en '>' knoppen om alle onderdelen van de 'Basiskenmerken' te doorlopen of klik direct op het te bewerken kenmerk (Begreppeling - Drainage - Beregening - Ligging - Structuur - Organische Stof - Hellingshoek - Kwel - OpbrengstCorrectie - BemestingsCorrectie).

- Waar nodig pas de informatie aan en klik op 'Bewaar'.

- Geldt de informatie voor alle percelen klik dan op 'Percelen Samen'. Wijzigingen worden dan ook voor alle percelen doorgevoerd.

Wijzigen van de Basiskenmerken van percelen kan ook uitgevoerd worden in 'Percelen voor bedrijf'.

- Klik boven in het scherm in de blauwe balk op 'Invoer'.

- Selecteer in het dropdown menu 'Percelen'. Onderstaand beeld verschijnt.

- Klik per perceel op $\theta$ 'Wijzig'.

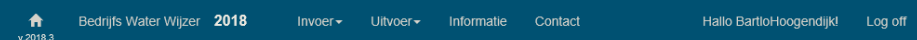
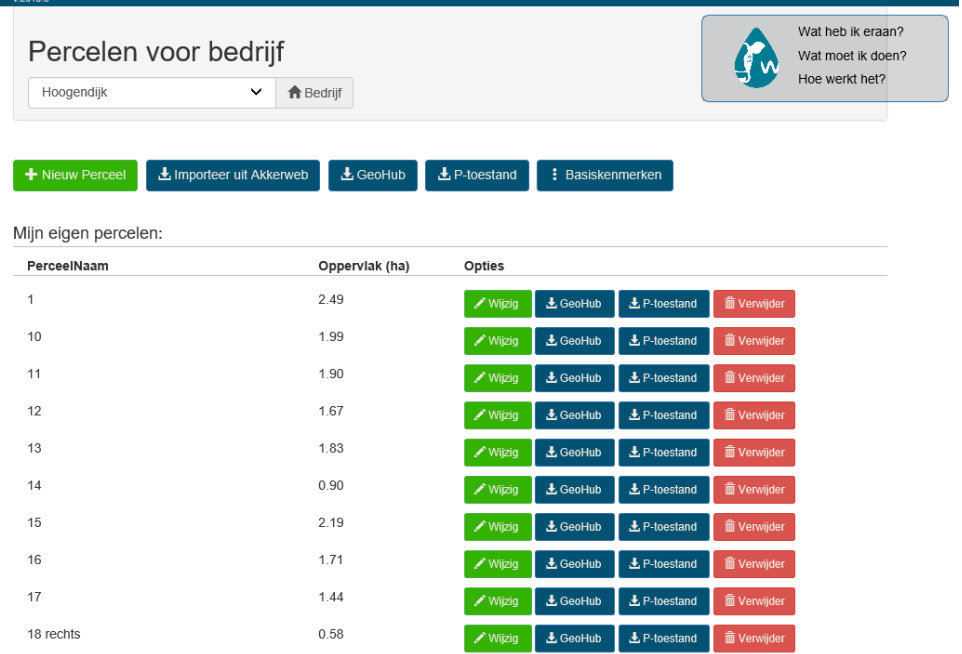

- In het scherm "Wijzig; Perceel" worden de eerder geïmporteerde en de eventueel eerder gewijzigde gegevens getoond.

- Controleer de gegevens over Gewas, Grondbewerking, Beweiding systeem, Opstallen, Jaren tussen herinzaai en Vruchtwisseling en pas deze indien nodig aan via de dropdown menu's.

- Kies bij 'Gewas' het juiste gewas en pas na een andere gewaskeuze vervolgens de gegevens aan. - Voor maïs de onderdelen 'Grondbewerking', 'Zaaidatum vanggewas', 'Vruchtwisseling' en 'PW-waarde'. 
- Voor gras, Rode klaver en rietzwenkgras de onderdelen 'Grondbewerking', Beweiding systeem', Jaren tussen herinzaai' en 'Vruchtwisseling'.

- Klik na het wijzigen van de gegevens op ‘Bewaar'.

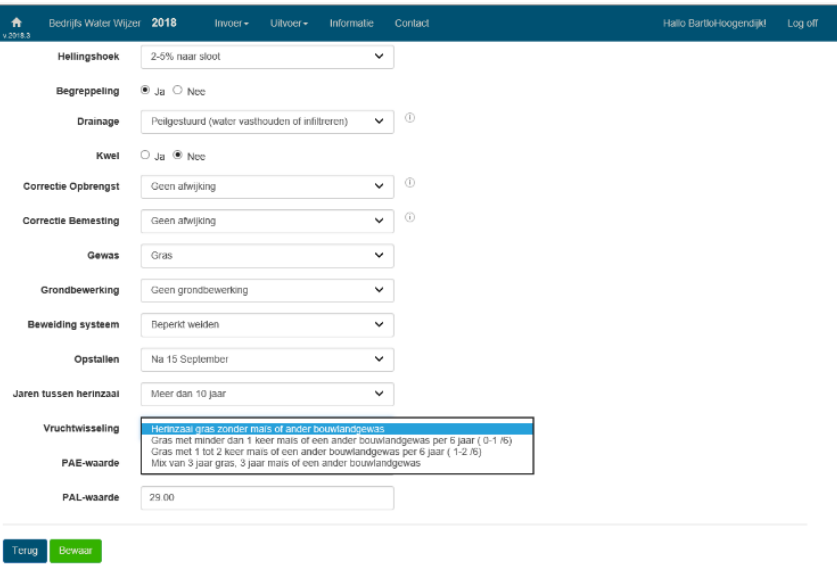

Indien nog een perceel ontbreekt, kan dat handmatig toegevoegd worden.

- Klik in het scherm "Percelen voor bedrijf” op '+Nieuw Perceel'.
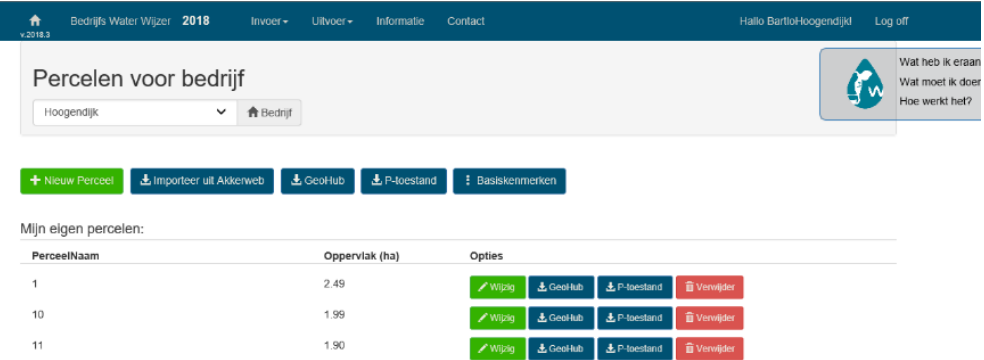

- Het scherm "Nieuw; Perceel” verschijnt.

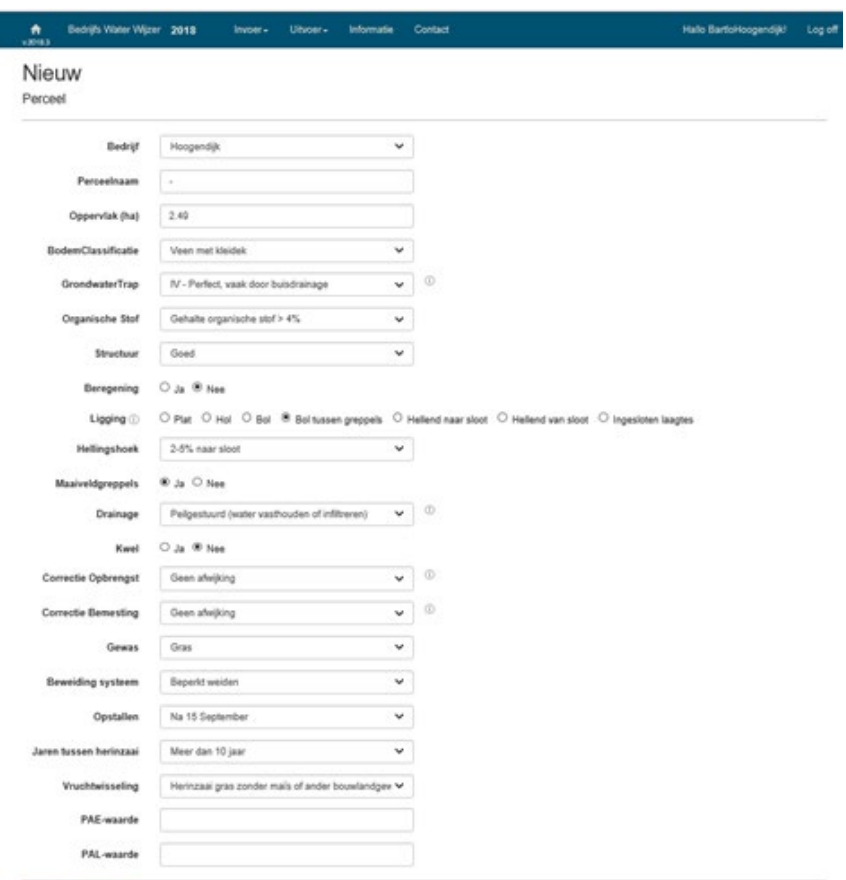


- Geef het perceel een naam en pas, waar nodig, de gegevens aan

- Klik na het wijzigen van de gegevens op 'Bewaar'.

- Het handmatig toegevoegde perceel verschijnt onderin de lijst (in dit voorbeeld naam Nieuw).

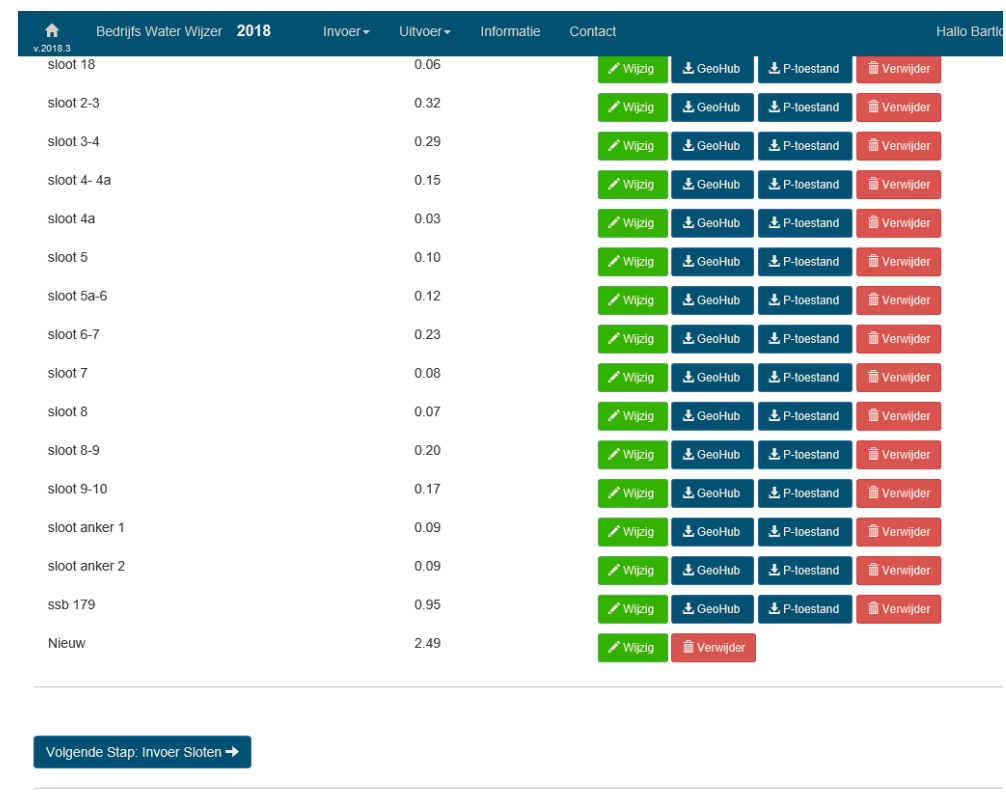

๑2019 - WUR

\subsection{Invoer sloten}

Aan de eerder ingevoerde percelen moeten, indien aanwezig, sloten gekoppeld worden. Hiervoor dienen eerst de sloten in de BWW ingevoerd te worden.

Als de import van percelen vanuit Akkerweb is gedaan, kunnen via de GeoHub service direct sloten geïmporteerd worden uit de Top-10 kaart van Nederland. Hierbij worden zowel de sloten als de koppeling tussen percelen en sloten (paragraaf 4.5) aangemaakt.

- Klik onderaan in het scherm "Percelen voor bedrijf" op 'Volgende Stap: Invoer Sloten'. Het scherm "Sloten voor bedrijf" verschijnt.

Indien $\mathrm{u}$ in het hoofdscherm staat:

- Klik boven in het scherm in de blauwe balk op 'Invoer'.

- Selecteer in het dropdown menu 'Sloten'. Het scherm "Sloten voor bedrijf" verschijnt.

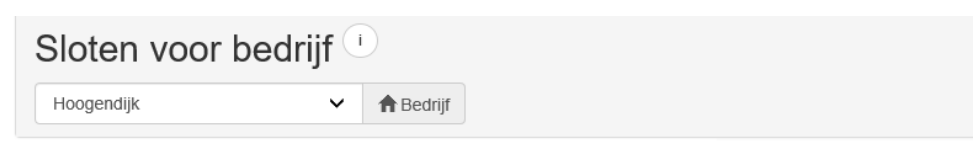

\section{+ Nieuwe Sloot $\downarrow$ GeoHub $\quad$ Basiskenmerken}

\begin{tabular}{|c|c|c|c|}
\hline Bedrijf & SlootNaam & Opties & \\
\hline Hoogendijk & Sloot-602074 & $>$ Wizig & î Verwijder \\
\hline Hoogendijk & Sloot-289570 & Nijzig & Ẽ Verwijder \\
\hline Hoogendijk & Sloot-614213 & $\Delta$ Wijig & Everwijder \\
\hline
\end{tabular}


Via de GeoHub worden de sloten vanuit de Top-10 kaart van Nederland toegevoegd aan percelen met geocoördinaten (Akkerweb percelen).

- Klik op 凶 'GeoHub'. Het scherm “GeoHub import” met daaronder de bedrijfsnaam verschijnt.

- Klik op 'Importeer'.

\section{Af Bedrifs Water Wizer 2018 Invoerv Uitvoerv Informatie Contact}

GeoHub import

Bedrijf Hoogendijk

De meest recente GeoHub gegevens worden voor al uw sloten langs uw percelen van bedrijf Hoogendijk opgehaald U kunt daarna de gegevens controleren, wizigen en goedkeuren voor elk van deze sloten.

\section{Terug Importeer}

(c) 2019 - WUR

De geografische gegevens van de sloten worden nu ingelezen.

Het scherm "Sloten voor bedrijf xxxxx" verschijnt.

$\mathrm{Na}$ inlezen kunnen per sloot de gegevens gecontroleerd en eventueel gewijzigd worden.

- Klik in het scherm "Sloten voor bedrijf" per sloot op $\&$ 'Wijzig'.

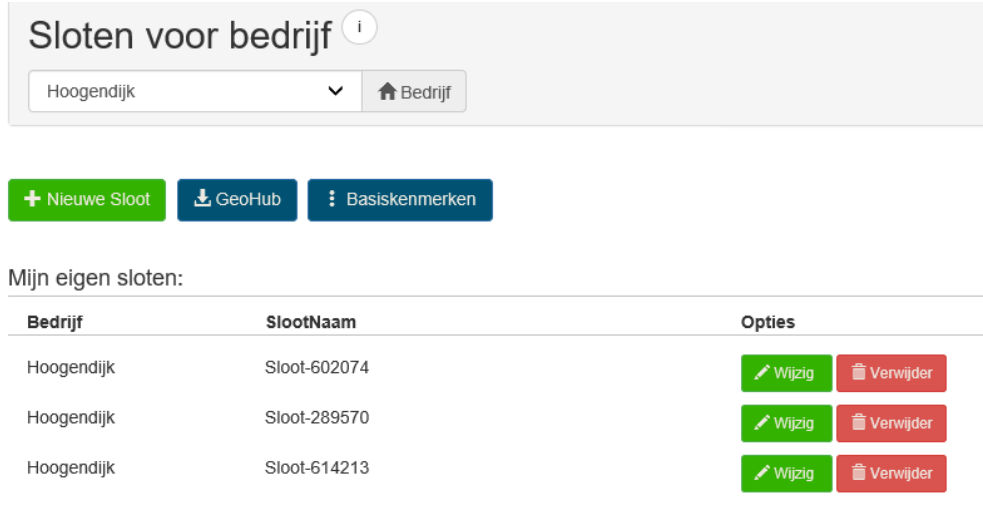

- Het scherm "Wijzig; Sloot op bedrijf xxxxx" verschijnt.

- Controleer en wijzig eventueel de gegevens.

- Klik op 'Bewaar'.

- Voer deze actie uit voor elke individuele sloot.

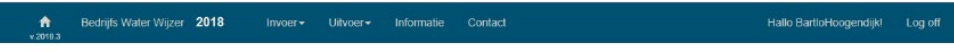

\section{Wijzig}

Sloot op bedrif Hoogendily
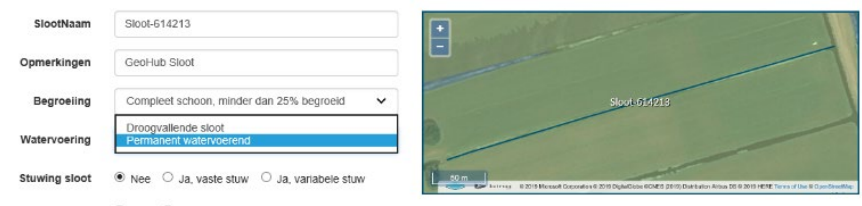

Onderbemaling -9 Nee $\bigcirc$ Ja 
In het scherm "Sloten voor bedrij" kunnen bij de knop 'Basiskenmerken' van alle sloten de basisgegevens per kenmerk (Begroeiing, Watervoering, Stuw en Onderbemaling) in één overzicht gewijzigd worden.

- Klik in het scherm "Sloten voor bedrijf" op 'Basiskenmerken'.

- Vink per sloot en per kenmerk de situatie aan.

- Klik op 'Bewaar' om de gegevens op te slaan.

- Met de knop 'Sloten Samen', kunnen de gegevens voor alle sloten tegelijk in één keer ingevuld worden. voor alle sloten tegelijk.

- Klik op '<' of '>' of de naam van het kenmerk om te navigeren tussen de kenmerken Begroeiing, Watervoering, Stuw en Onderbemaling.

Bewerk Basiskenmerken voor Sloten

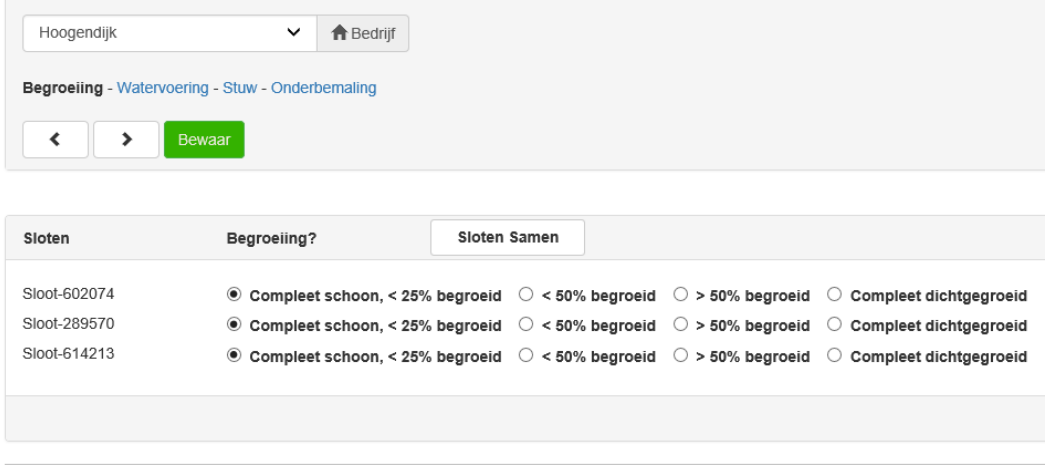

Teng

๑ 2019 - WUR

Voeg indien van toepassing sloten toe.

- Klik in het scherm "Sloten voor bedrijf" op '+ Nieuwe sloot'

$$
\begin{aligned}
& \text { Sloten voor bedrijf } \\
& \begin{array}{ll}
\text { Hoogendijk } & \sim \text { A Bedrijf }
\end{array}
\end{aligned}
$$

\begin{tabular}{|c|c|c|c|}
\hline Bedrijf & SlootNaam & Opties & \\
\hline Hoogendijk & Sloot-602074 & Wizig & Â Verwijder \\
\hline Hoogendijk & Sloot-289570 & Wizig & Â Verwijder \\
\hline Hoogendijk & Sloot-614213 & Wijzig & A Verwijder \\
\hline
\end{tabular}

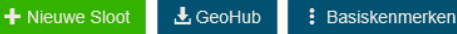

\section{Volgende Stap: Koppeling Perceel en Sloot $\rightarrow$}

(๑) 2019 - WUR

- Vul de gegevens voor de nieuwe sloot in en klik op 'Bewaar'.

- Er kunnen meerdere nieuwe sloten ingevoerd worden door opnieuw te klikken op '+Nieuwe sloot'. 


\section{A Bedrifs Water Wijzer 2018 Invoer - Uitvoer- Informatie Contact}

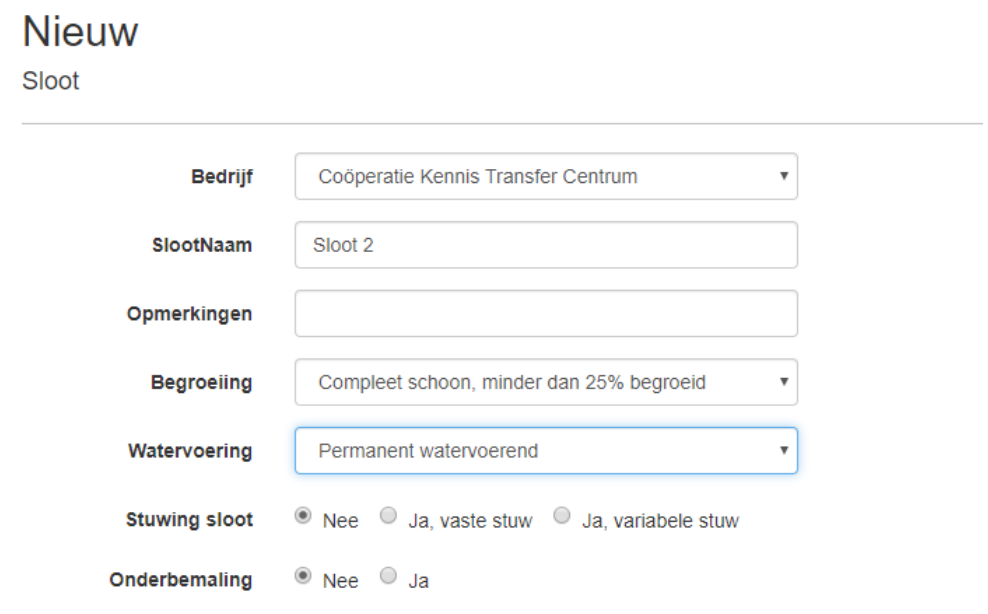

\section{Terug Bewaar}

(C) 2019 - WUR

\subsection{Koppelen sloten-percelen}

Via de GeoHub worden percelen met geografische informatie automatisch gekoppeld aan naastgelegen sloten en andere waterpartijen. Het kenmerk grenslengte tussen perceel en sloot wordt daarbij uitgerekend. De richting van de bewerking van het land ten opzichte van de sloot dient nog wel ingegeven te worden.

- Klik onderaan in het scherm "Sloten voor bedrij" op 'Volgende Stap: Koppeling Perceel en Sloot'. Het scherm "Sloten langs percelen (grenzen) voor bedrijf xxxxx" verschijnt.

Indien $\mathrm{u}$ in het hoofdscherm staat:

- Klik boven in het scherm in de blauwe balk op 'Invoer'.

- Selecteer in het dropdown menu 'Koppeling Perceel Sloot. Het scherm "Sloten langs percelen (grenzen) voor bedrijf xxxxx" verschijnt.

\section{Sloten voor bedrijf \\ \begin{tabular}{l|l|l}
\hline Hoogendijk & $\checkmark$ & Bedrijf \\
\hline
\end{tabular}}

\section{+ Nieuwe Sloot $\downarrow$ GeoHub $\quad$ Basiskenmerken}

\begin{tabular}{|c|c|c|c|}
\hline Bedrijf & SlootNaam & Opties & \\
\hline Hoogendijk & Sloot-602074 & A Wizig & Ê Verwijder \\
\hline Hoogendijk & Sloot-289570 & Wijzig & Î Verwijder \\
\hline Hoogendijk & Sloot-614213 & Wijig & Ê Verwijder \\
\hline
\end{tabular}

\section{Volgende Stap: Koppeling Perceel en Sloot $\rightarrow$}

(๑) 2019 - WUR

- Klik bij een sloot op $\&$ 'Wijzig' en wijzig de gegevens. 
- Klik na het wijzigen op 'Bewaar' om de gegevens op te slaan.

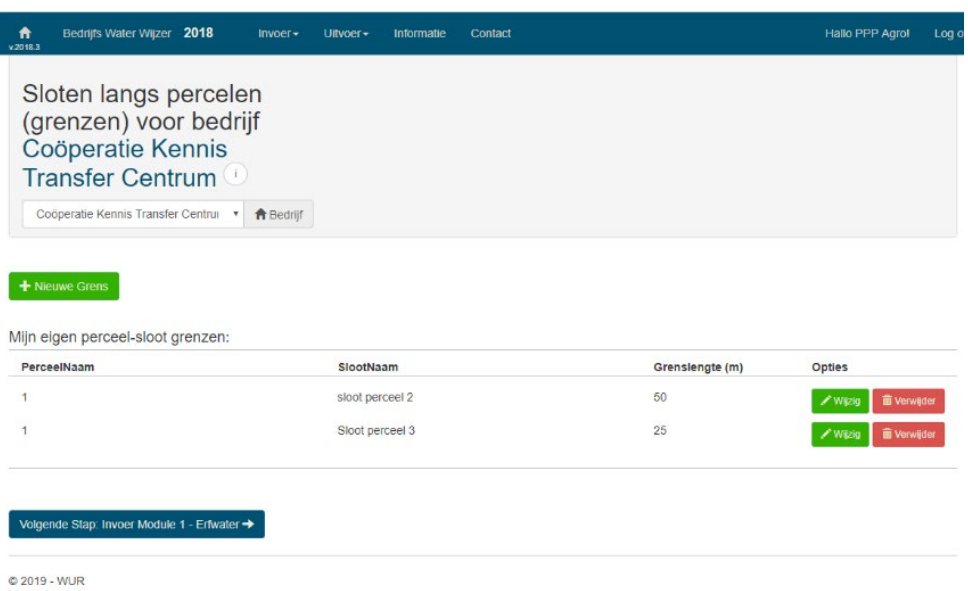

Wanneer een handmatig ingevoerde sloot nog niet aan een perceel is gekoppeld, kan dat handmatig uitgevoerd worden.

- Klik op ‘+Nieuwe Grens'. Het scherm “Nieuw; Nieuwe relatie tussen perceel en sloot” verschijnt.

- Klik bij 'Sloot' $\quad \nabla$ op voor het dropdown menu. Kies in dit menu de sloot die gekoppeld moet worden.

- Selecteer op dezelfde wijze het perceel wat aan de eerder geselecteerde sloot gekoppeld moet worden.

- Klik na invoeren op 'Bewaar' om de gegevens op te slaan.

Af $\quad$ Bedrijfs Water Wijzer $2018 \quad$ Invoer v Uitvoerv Informatie Conta

\section{Nieuw}

Nieuwe relatie tussen perceel en sloot

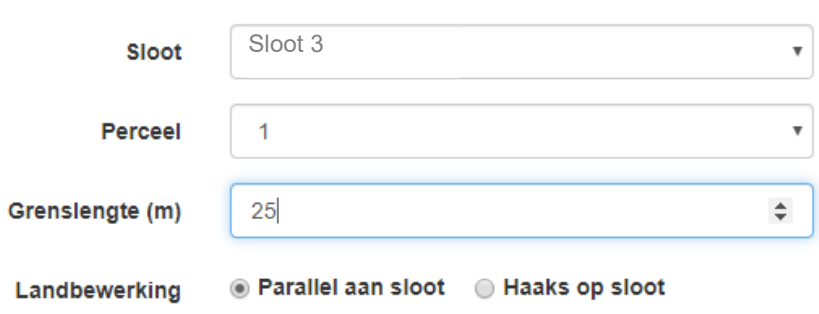

\subsection{Module 1 - Gegevens Erf}

Vanuit deze module start u een Erfscan bij Broos Water, herkenbaar aan het label 'AgriWijzer'. De resultaten komen beschikbaar binnen de BedrijfsWaterWijzer, waardoor u een beeld krijgt van de actuele risico's van vervuiling door erfwater.

Het onderdeel ERF in de BedrijfsWaterWijzer is ontwikkeld door adviesbureau Broos Water uit Luttelgeest en is gebaseerd op de Erfemissiescan Veehouderij, een digitale tool waarmee (melk)veehouders eenvoudig het risico op emissie van nutriënten vanaf hun erf in kaart kunnen brengen. Daarnaast geeft de tool informatie over maatregelen om emissie vanaf het erf te verminderen. Daarmee maakt de Erfemissiescan Veehouderij (melk)veehouders bewust van de risico's op erfemissie op het eigen bedrijf en geeft het handvatten om de erfsituatie te verbeteren om 
daarmee te voldoen aan de actuele milieuregels en voorschriften in het Activiteitenbesluit Milieubeheer (Amb). Deze scan is in 2015 door Broos Water in eigen beheer ontwikkeld.

\section{Stap1 Opstarten Erfscan Veehouderij in de BWW}

Klik onderaan in het scherm "Sloten langs percelen (grenzen) voor bedrijf <bedrijfsnaam>" op "Volgende Stap: Invoer Module 1 Erfwater'. Het scherm "Erf" verschijnt.

\section{Stap2 Selecteren van erfonderdelen}

$\mathrm{Na}$ het opstarten ziet $\mathrm{u}$ een schets van een veehouderijbedrijf. $U$ kunt nu een onderdeel van het bedrijf selecteren door op een nummer te gaan staan (zgn. hotspot) en per onderdeel 5 stappen doorlopen:

\begin{tabular}{|c|c|}
\hline Regelgeving & $\begin{array}{l}\text { Voor ieder onderdeel van het bedrijf leest u hier in 'boerentaal' welke } \\
\text { milieuregels en voorschriften van toepassing zijn. }\end{array}$ \\
\hline Vragenlijst & $\begin{array}{l}\text { Per erfonderdeel kunt u een vragenlijst invullen. U kunt per vraag één of } \\
\text { meerdere antwoorden selecteren die het beste aansluiten bij de erfsituatie van } \\
\text { dat onderdeel op uw bedrijf. }\end{array}$ \\
\hline Resultaat & $\begin{array}{l}\text { Na het invullen van de vragenlijst worden de door u gegeven antwoorden } \\
\text { getoetst aan de actuele milieuregels en voorschriften. Op de tekening worden } \\
\text { onderstaande icoontjes zichtbaar: }\end{array}$ \\
\hline & $\begin{array}{l}\text { E) Er zijn geen aandachtspunten. } U \text { voldoet voor dit onderdeel aan de actuele } \\
\text { regels en eisen. }\end{array}$ \\
\hline & $\begin{array}{l}\text { A) U voldoet voor dit onderdeel aan de regels en eisen, maar er zijn wel } \\
\text { verbeteringen mogelijk. }\end{array}$ \\
\hline & $\begin{array}{l}\text { X) Er zijn aanpassingen nodig om voor het betreffende onderdeel aan de regels e } \\
\text { eisen te voldoen. }\end{array}$ \\
\hline Advies & $\begin{array}{l}\text { Indien nodig krijgt u op basis van het resultaat per erfonderdeel één of meerdere } \\
\text { verbeterpunten (advies). }\end{array}$ \\
\hline Oplossingen & $\begin{array}{l}\text { Indien nodig kunt u praktische en bruikbare oplossingen raadplegen waarmee u } \\
\text { uw erfsituatie kunt verbeteren met (bovenwettelijke) oplossingen. }\end{array}$ \\
\hline
\end{tabular}

\section{Stap 3 Risico's bekijken}

Elk onderdeel van de Erfscan Veehouderij bevat een vragenlijst in de vorm van een beslisboom. De antwoorden op de vragen representeren een score. Op basis van deze score wordt het risico op vervuiling van het oppervlaktewater in kaart gebracht.

Door linksboven in de tool op het pijltje te klikken (zie afbeelding) komt $u$ terug in het beginscherm van de bedrijfswaterwijzer en kunt $u$ deze resultaten bekijken.

\section{Oude tekst/kan weg}

Indien $\mathrm{u}$ in het hoofdscherm staat:

- Klik boven in het scherm in de blauwe balk op 'Invoer'.

- Selecteer in het dropdown menu onder 'Modulegegevens', '1 Erf'. Koppeling Perceel Sloot. Het scherm "Sloten langs percelen (grenzen) voor bedrijf <bedrijfsnaam>" verschijnt.

$\bullet$

- Klik op i voor informatie waarom en met welk hulpprogramma dit onderdeel wordt ingevuld.

- Klik op 'Start Erfscan'. De AgriWijzer BedrijfswaterWijzer (erf) wordt opgestart.

- Klik op 'Start de scan'; het scherm "Hoe gebruikt u deze tool?" verschijnt.

- Klik op de onderdelen links onder het plaatje en vul de vragenlijsten in. 


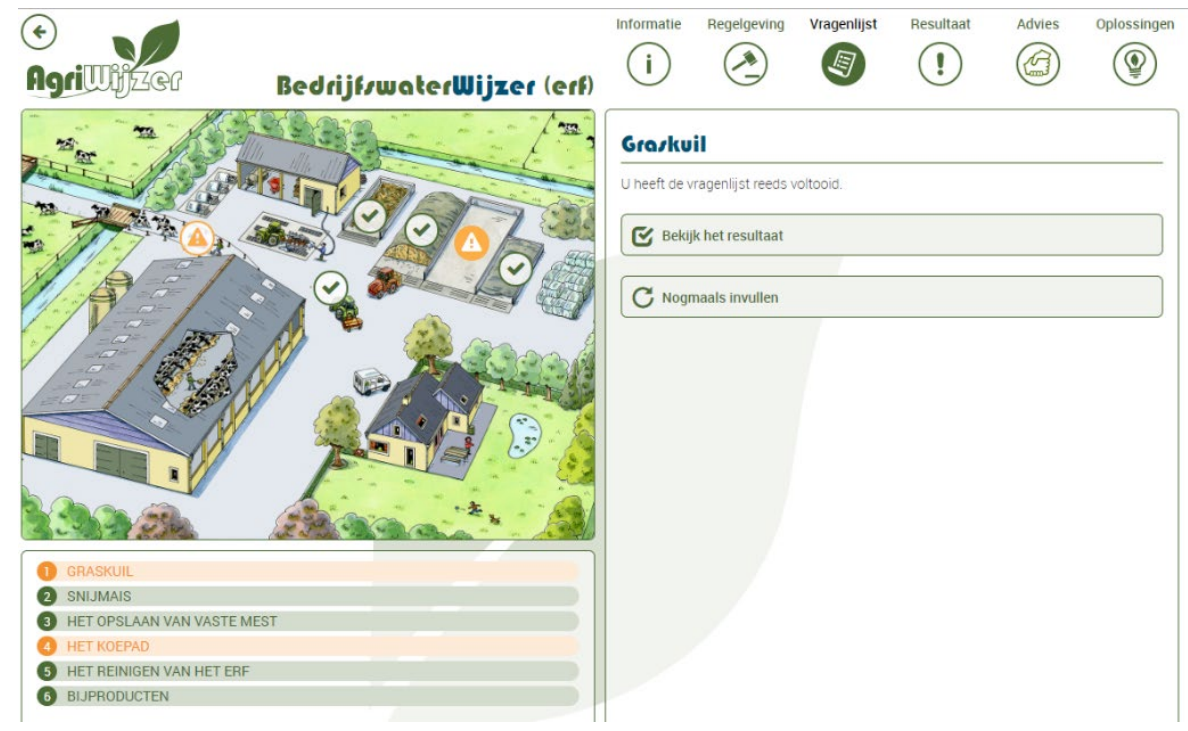

- Ga met pijltjes linksboven $\Theta($ ) vanuit de AgriWijzer omgeving terug naar het hoofdscherm van de BedrijfsWaterWijzer.

\subsection{Module 2 - Gegevens Droogte}

$\mathrm{Na}$ afronden van de module BedrijfsWaterWijzer (erf) verschijnt het scherm met de module "Erf".

- Klik op 'Volgende Stap: Invoer Module 2 - Droogte $\rightarrow$ '.

\section{B. Bedrijfs Water Wijzer 2018 Invoerv Uitvoerv}

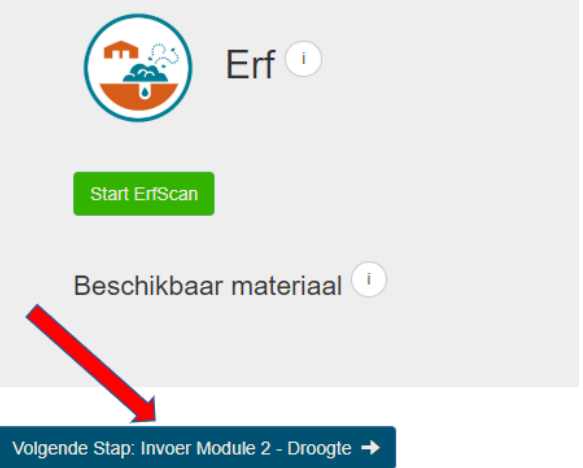

Het scherm "Droogte" verschijnt. In deze module worden aanvullende gegevens rondom het thema droogte gevraagd.

- Klik op 'Bewerk Waarden'. 


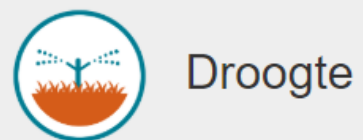

Voor de module Droogte worden wat extra gegevens opgevraagd die van belang zijn voor:

- het vasthouden van neerslag

- het voldoende aanvullen van grondwater (voor bijvoorbeeld drinkwaterwinning)

- het voorkomen van pieken in de neerslagafvoer

- het efficiënt beregenen van prorcelen

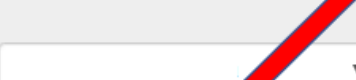

- A Bedriif

Bewerk Waarden

Volgende Stap: Invoer Module 4 - Uitspoeling $\rightarrow$

Een scherm met daarin een aantal mogelijkheden verschijnt.

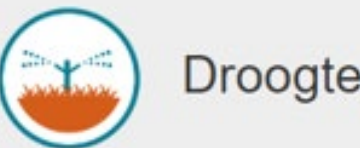

Voor de module Droogte worden wat extra gegevens opgevraagd die van belang zijn voor:

- het vasthouden van neerslag

- het voldoende aanvullen van grondwater (voor bilvoorbeeld drinkwaterwinning)

het voorkomen van pieken in de neerslagafvoer

- het efficient beregenen van percelen

\section{A Bedrijf}

\section{Gegevens gebied}

Waterhuishouding

Peilbeheerst (poider)

Drooglegging

Beperkte drooglegging $(40-60 \mathrm{~cm}-\mathrm{mv})$

\section{Gegevens beregening}

\begin{tabular}{c|l|} 
Sector-instelling & anders \\
Strategie gras/klaver & Geen beregening \\
Strategie mais & \\
&
\end{tabular}


- Klik op 'Terug' als u terug wilt naar het vorige scherm. Er wordt gerekend met de standaard waarden voor droogte.

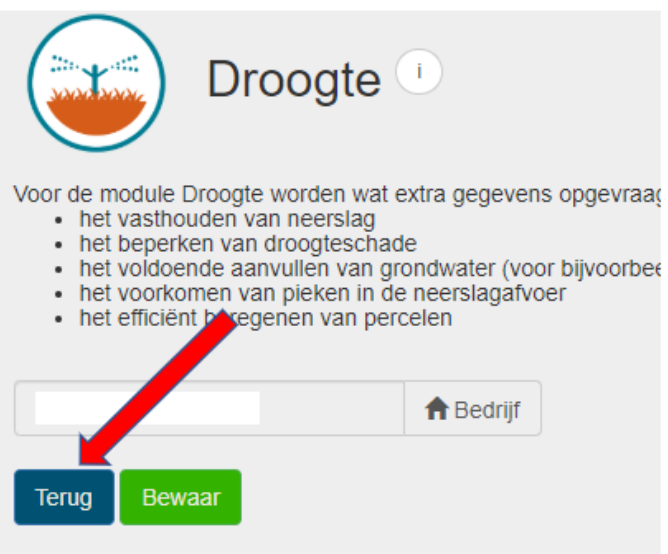

Om de gegevens over droogte te wijzigen, kunnen de invoervelden "Gegevens gebied" en "Gegevens beregening" doorlopen worden.

- Klik in het invoerveld "Gegevens gebied" op het dropdown menu rechts van "Waterhuishouding". - Kies 'Peilbeheerst (polder)" als sprake is van een gestuurd peil door middel van stuwen en gemalen.

- Kies 'Vrij afwaterend' als het water vrij kan wegstromen naar het laagste punt zonder enige belemmering.

\section{Gegevens gebied}

\begin{tabular}{|c|l|}
\hline Waterhuishouding & Peilbeheerst (polder) \\
\hline Drooglegging & Prij afwaterend \\
\hline
\end{tabular}

- Klik in het invoerveld "Gegevens gebied" op het dropdown menu rechts van "Drooglegging".

- Kies een drooglegging die past bij de situatie op het bedrijf.

- In de huidige versie van de BedrijfsWaterWijzer wordt geen onderscheid gemaakt tussen zomer- en winterpeil. Advies op dit moment is uit te gaan van het zomerpeil.

\section{Gegevens gebied}

\begin{tabular}{|l|l|}
\hline Drooglegging & $\begin{array}{l}\text { Peilbeheerst (polder) } \\
\text { Begerkte drooglegging }(40-60 \mathrm{~cm}-\mathrm{mv})\end{array}$ \\
\hline $\begin{array}{l}\text { Grote drooglegging }(>80 \mathrm{~cm}-\mathrm{mv}) \\
\text { Matige drooglegging }(60-80 \mathrm{~cm}-\mathrm{mv})\end{array}$ \\
\hline $\begin{array}{l}\text { Beperkte drooglegging }(40-60 \mathrm{~cm}-\mathrm{mv}) \\
\text { Geringe drooglegging }(0-40 \mathrm{~cm}-\mathrm{mv})\end{array}$ \\
\hline
\end{tabular}

- Klik in het invoerveld "Gegevens beregening" op het dropdown menu rechts van "Sector-instelling". Hierin wordt een keuze gemaakt voor het aantal graden die de sproeikop draait tijdens het beregenen.

- Kies '220 graden' als de sproeikop van links naar rechts gaat en daarna weer links begint (of van rechts naar links en weer op rechts begint).

- Kies '360 graden' als de sproeikop volledig ronddraait.

- Kies 'anders' indien er beregend wordt met bijvoorbeeld een sproeiboom. 
Gegevens beregening

\begin{tabular}{c|l|}
\hline \multirow{3}{*}{ Sector-instelling } & anders \\
\hline \multirow{3}{*}{ Strategie gras/klaver } & $\begin{array}{l}220 \text { graden } \\
360 \text { graden } \\
\text { anders }\end{array}$ \\
\cline { 2 - 2 } & Geen beregening \\
&
\end{tabular}

- Klik in het invoerveld "Gegevens beregening" op het dropdown menu rechts van "Strategie gras/klaver". Hierbij wordt de beste optie gekozen die past bij het beregenen van de percelen waarop gras/klaver wordt verbouwd. De optie 'Geen beregening' is standaard.

Gegevens beregening

\begin{tabular}{|l|l|} 
Sector-instelling & anders \\
\cline { 2 - 2 } Strategie gras/klaver mais & $\begin{array}{l}\text { Geen beregening } \\
\text { Beregenen op maat } \\
\text { Suboptimaal door te lage capaciteit } \\
\text { Alleen voor behoud graszode } \\
\text { Geen beregening }\end{array}$ \\
\hline
\end{tabular}

- Klik in het invoerveld "Gegevens beregening" op het dropdown menu rechts van "Strategie maïs". Hierbij wordt de beste optie gekozen die past bij het beregenen van de percelen waarop maïs wordt verbouwd. De optie 'Geen beregening' is standaard.

\section{Gegevens beregening}

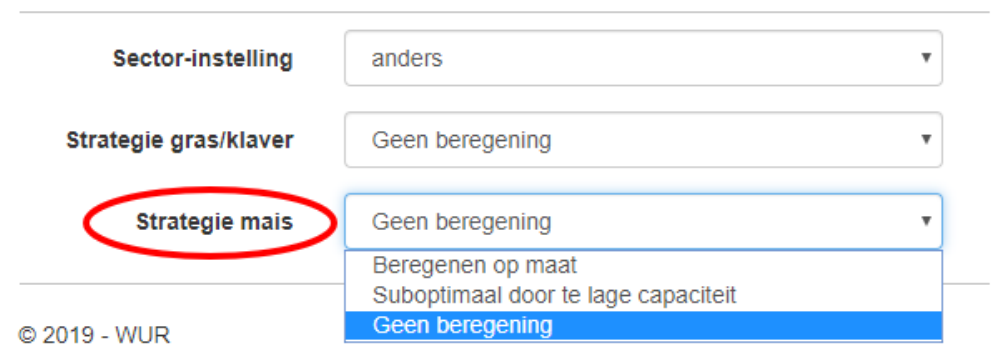

- Klik op 'Bewaar' als u aan de invoer niets meer wilt veranderen. De invoerschermen van de module "Droogte" worden afgesloten.

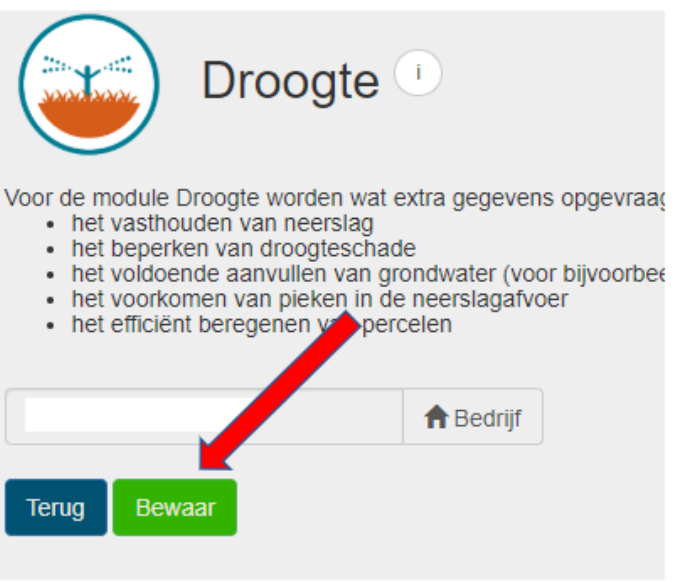

Het hoofdscherm van de module "Droogte" verschijnt. 
- Klik op 'Volgende Stap: Invoer Module 4 - Uitspoeling $\rightarrow$ '. Het openingsscherm van module 4 "Uitspoeling" verschijnt.

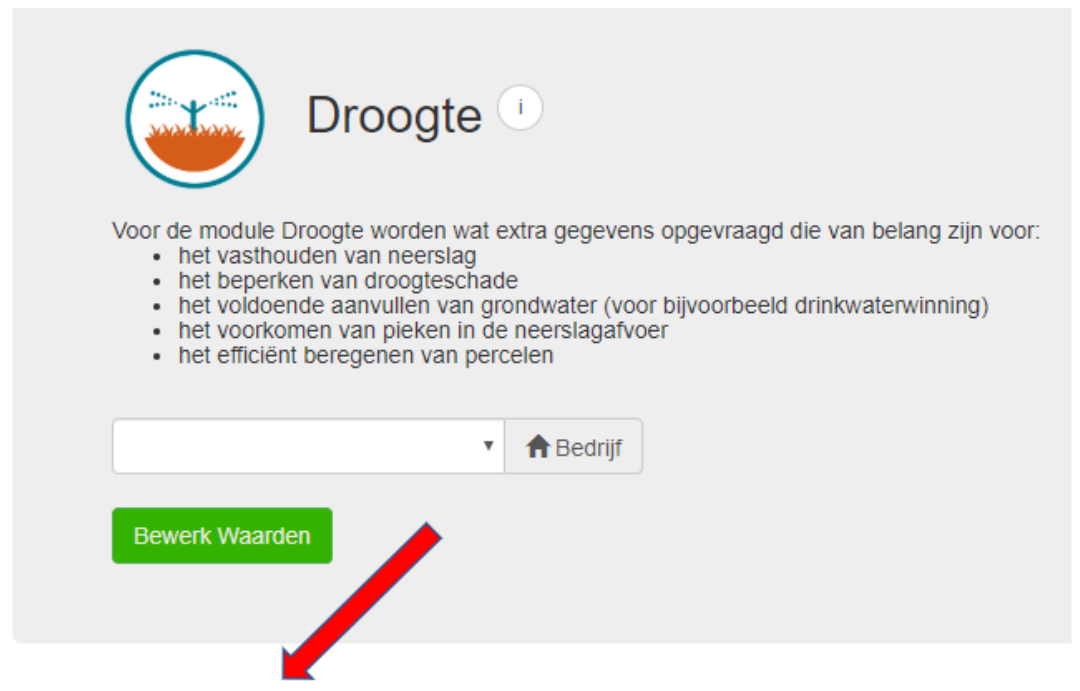

Volgende Stap: Invoer Module 4 - Uitspoeling $\rightarrow$

Let op: u gaat van module 2 "Droogte" naar module 4 "Uitspoeling"!

\subsection{Module 3 - Gegevens Wateroverlast}

Module 3 "Wateroverlast" vraagt geen aanvullende informatie. Deze module is in ontwikkeling.

\subsection{Module 4 - Gegevens Uitspoeling}

In deze module worden aanvullende gegevens gevraagd voor het in kaart brengen van de uitspoeling op de percelen. Hiervoor worden additionele vragen gesteld die betrekking hebben op het merendeel van een perceel en vragen die betrekking hebben op kleinere afwijkende plekken op een perceel.

\section{Additionele vragen bodemkenmerken van een perceel}

- Klik op 'Additionele bodemkenmerken perceel'. Een scherm met alle percelen van het bedrijf verschijnt. Hierin kan per perceel additionele kenmerken aangevinkt worden.

\section{A Bedrijfs Water Wijzer $2018 \quad$ Invoer v Uitvoer - Informatie Contac}

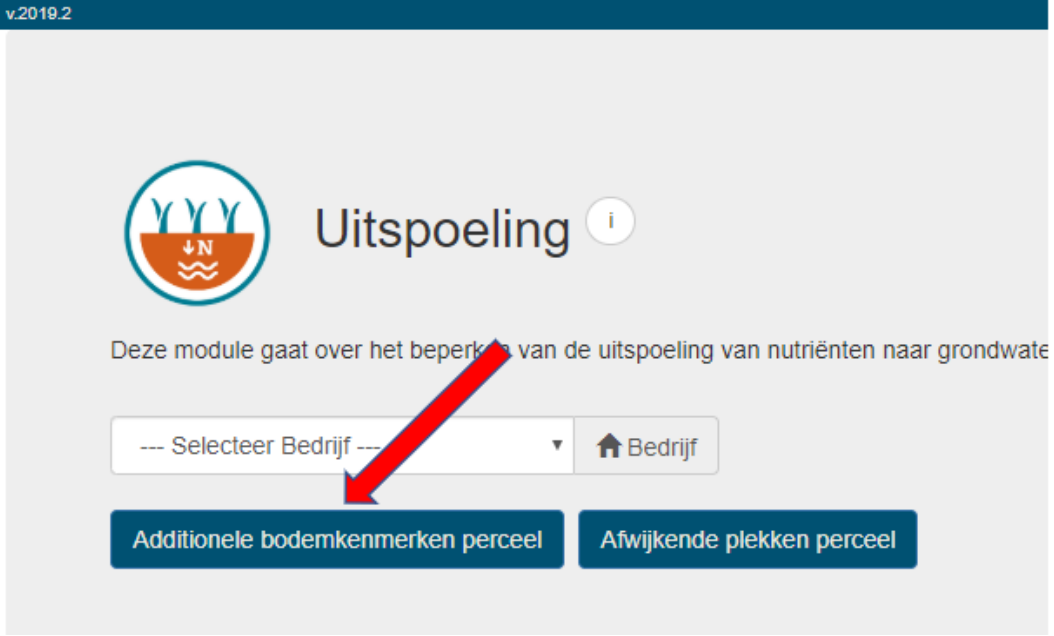


- Bij veen zijn 3 aanvullingen mogelijk. Vink aan indien van toepassing.

$\begin{array}{lll}\text { Veenpercelen } & \begin{array}{l}\text { Lichte minerale laag incl. zand } \\ \text { diepte }<120 \mathrm{~cm}-\mathrm{mv}\end{array} & \begin{array}{l}\text { Lichte minerale laag incl. zand } \\ \text { diepte }>120 \mathrm{~cm}-\mathrm{mv}\end{array} \\ 11 \text { hond } & \square\end{array}$

- Bij kleigrond zijn 5 aanvullingen mogelijk. Vink aan indien van toepassing.

Kleipercelen

Verdichting of slecht
doorlatende laag $(<50$
cm-mv)

achter freek brouwer

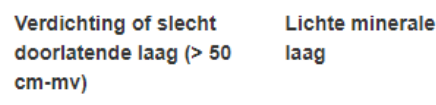

Lichte minerale

Veen of moerige

$\square$ $\square$ laag

Scheurvorming

(1)

- Bij zand en lösspercelen zijn 5 aanvullingen mogelijk. Vink aan indien van toepassing.

\begin{tabular}{llllll}
\hline Zand en löss percelen & $\begin{array}{l}\text { Verdichting of slecht } \\
\text { doorlatende laag }(<50 \\
\mathrm{cm}-\mathrm{mv})\end{array}$ & $\begin{array}{l}\text { Verdichting of slecht } \\
\text { doorlatende laag }(>50 \\
\mathrm{cm}-\mathrm{mv})\end{array}$ & $\begin{array}{l}\text { Lichter (grover) } \\
\text { materiaal }\end{array}$ & $\begin{array}{l}\text { Veen of moerige } \\
\text { laag }\end{array}$ \\
11 hond & $\square$ & $\square$ & $\begin{array}{l}\text { Zwaarder materiaal } \\
\text { (klei/leem) }\end{array}$
\end{tabular}

- Scrol na het nalopen van alle percelen omhoog en klik op 'Bewaar'. Het hoofdscherm van de module "Uitspoeling" verschijnt.

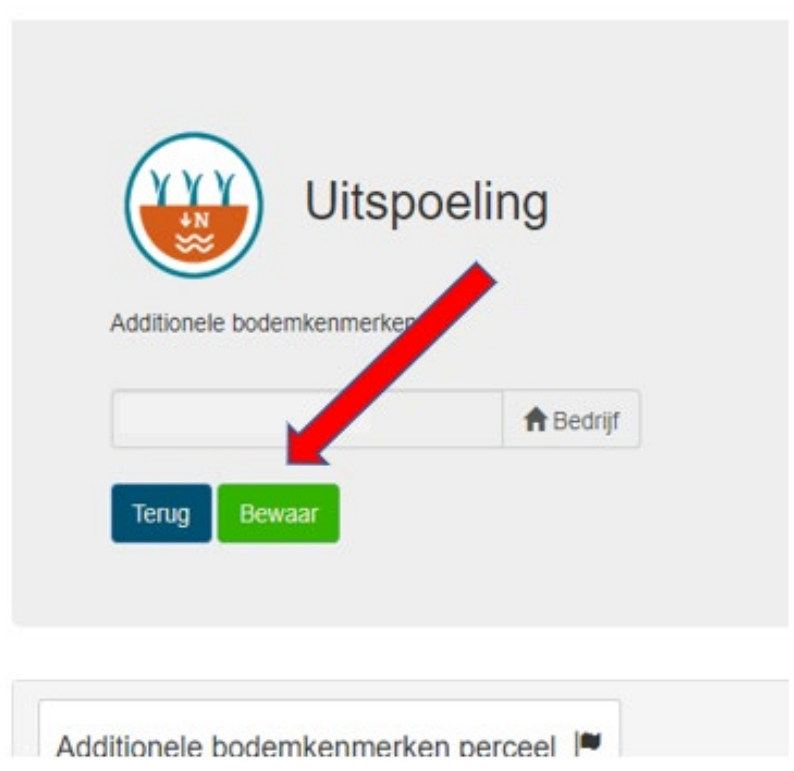




\section{Additionele vragen afwijkende plekken op een perceel}

- Klik op 'Afwijkende plekken perceel'.

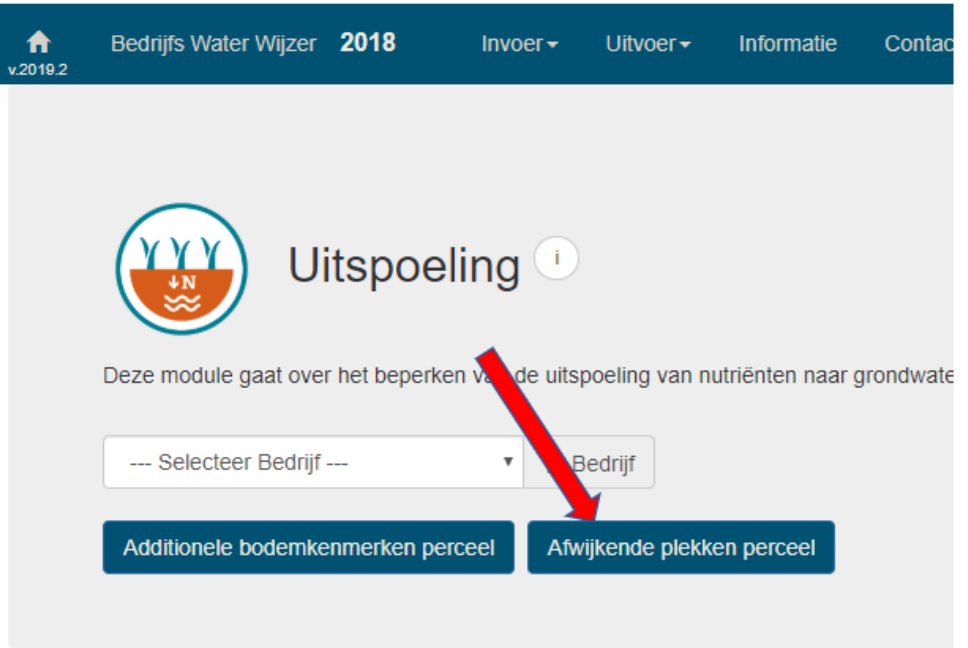

Volgende Stap: Invoer Module 5 - Afspoeling $\rightarrow$

- Klik op 'Terug' indien er toch geen afwijkende plekken zijn of u zich heeft vergist.

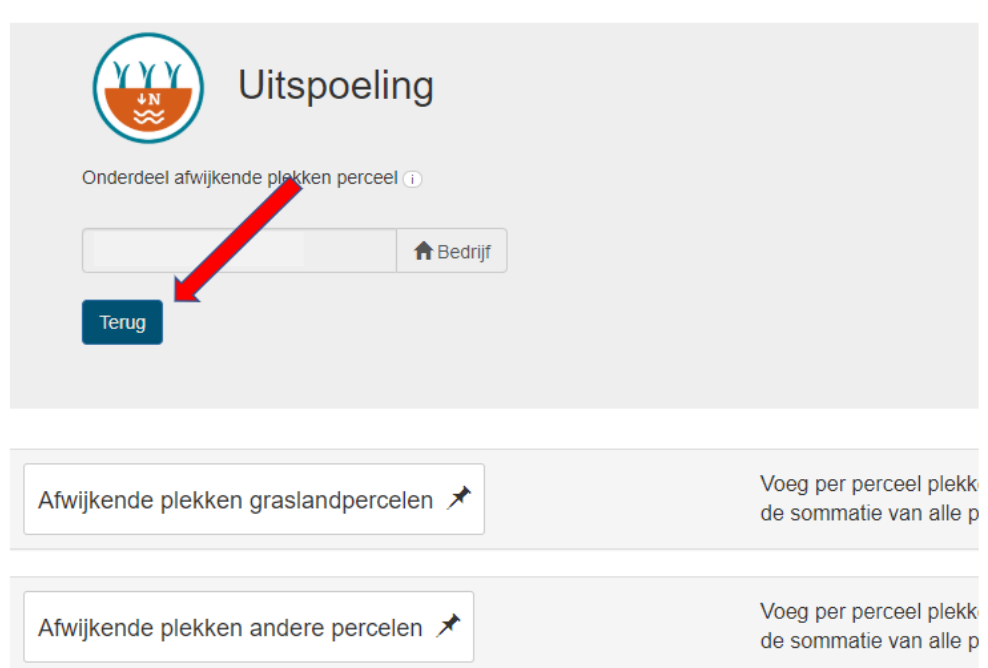

- Klik op 'Afwijkende plekken graslandpercelen' indien er op de percelen grasland afwijkende plekken zijn. Een scherm verschijnt met alle graslandpercelen.

- Ga naar het perceel waarop zich een afwijkende plek bevindt.

- Klik op '+ Nieuwe Plek op <perceelsnaam>'. Een keuzemenu verschijnt.

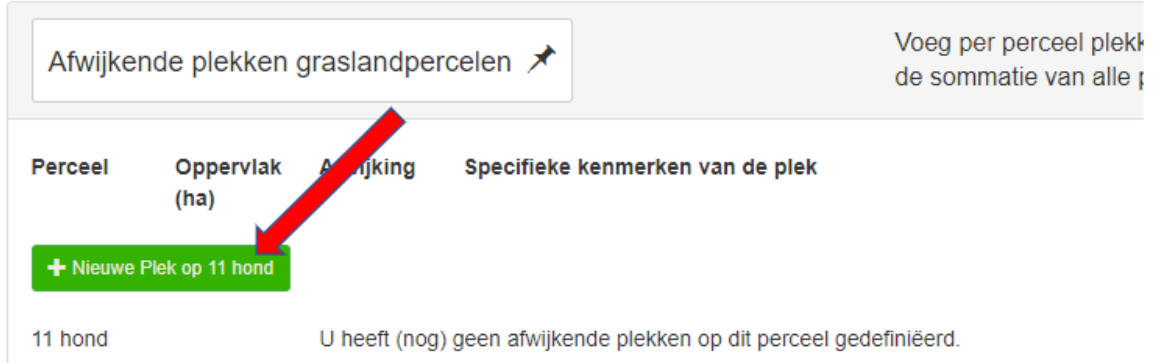

- Ga met de muisaanwijzer over de thema's. Bij elk thema verschijnt een korte uitleg over de inhoud van het thema. 
- Klik op het thema wat het best de afwijkende plek omschrijft. Een scherm verschijnt waarin u de afwijkende plek nader kunt karakteriseren.

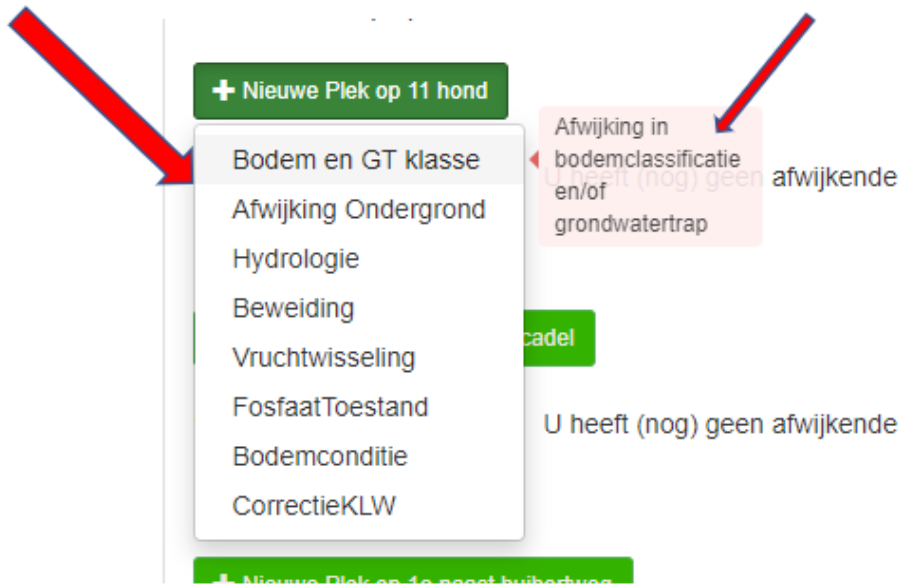

- Klik op 'Terug' in een gekozen thema indien er toch geen afwijkende plek is of $u$ heeft zich vergist.

\section{Nieuw}

Afwijkende plek bodem

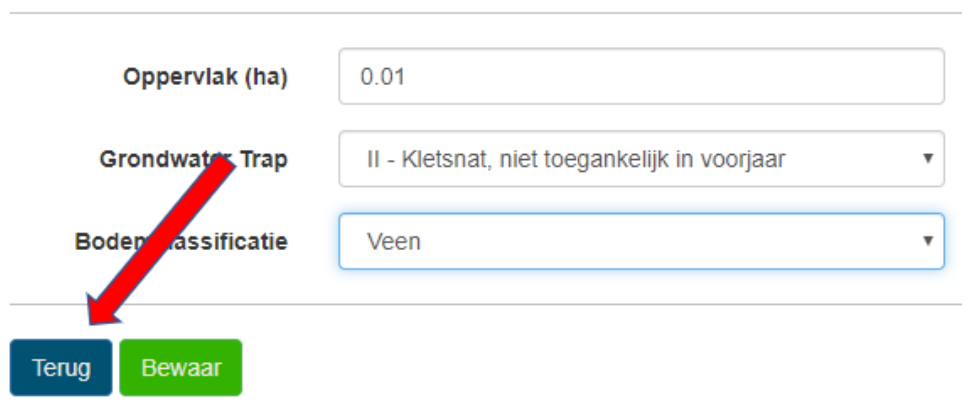

Indien er wel een afwijkende plek is:

- Klik op het thema wat het best de afwijkende plek omschrijft. Een scherm verschijnt waarin u de afwijkende plek nader kunt karakteriseren.

Verderop in deze paragraaf worden de verschillende thema's besproken.

$\mathrm{Na}$ invullen van de opties bij elk thema:

- Klik op 'Bewaar' indien van het geselecteerde perceel de afwijkende plek is gekarakteriseerd. Het submenu van de module "Uitspoeling" waarin afwijkende plekken kunnen worden gekarakteriseerd verschijnt.

\section{Nieuw}

Afwijkende plek bodem

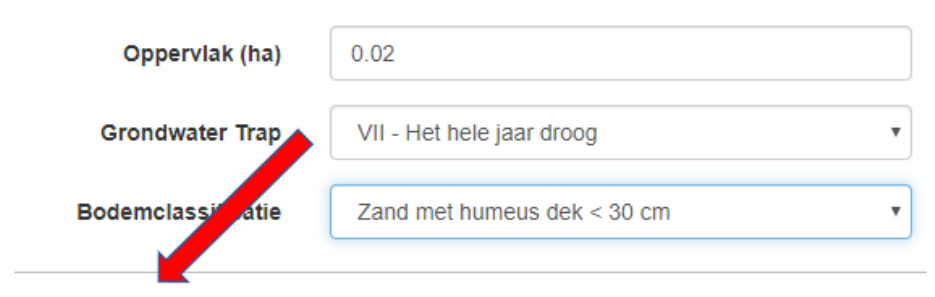


- Klik wederom op 'Afwijkende plekken graslandpercelen' indien:

1. Bij een perceel wat al een afwijkende plek heeft nog een afwijkende plek ingevoerd moet worden.

- Klik op '+ Nieuwe Plek op <perceelsnaam> en vul het volgende thema voor de afwijkende plek in en bewaar de gegevens.

2. Op een ander perceel een afwijkende plek ingevoerd moet worden

Het aangeven en karakteriseren van een of meerdere afwijkende plek(ken) op een andere perceel, wordt uitgevoerd volgens dezelfde wijze als voorgaande beschreven.

3. als een eerder ingevoerde afwijkende plek gewijzigd of verwijderd moet worden.

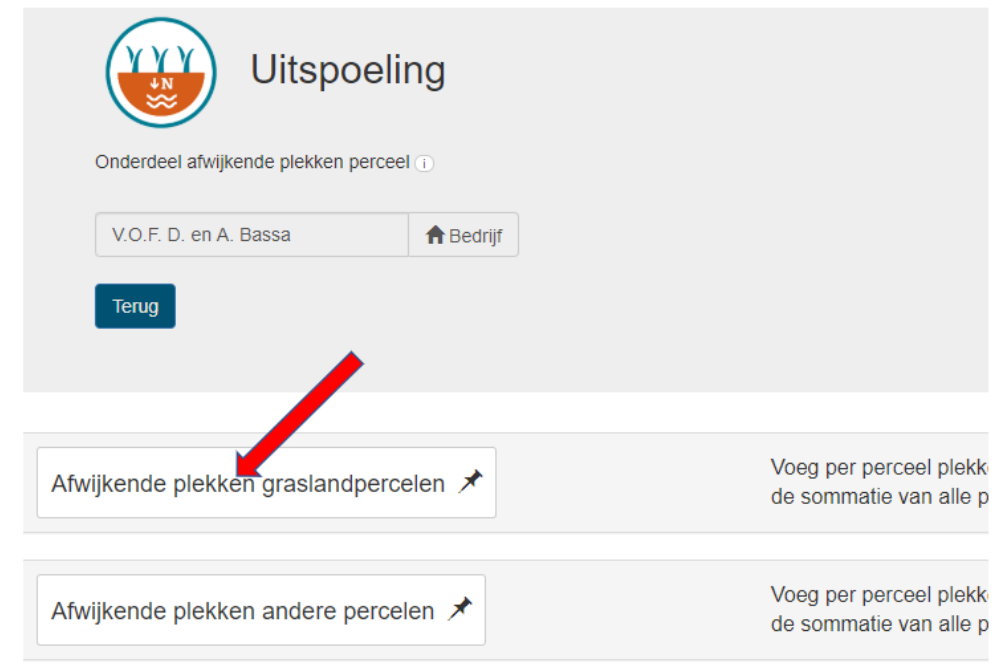

\section{Bespreking thema's afwijkende plekken graslandpercelen}

Thema: Bodem en GT klasse

- Klik op 'Bodem en GT klasse. Het scherm voor het karakteriseren van de "Afwijkende plek Bodem" verschijnt.

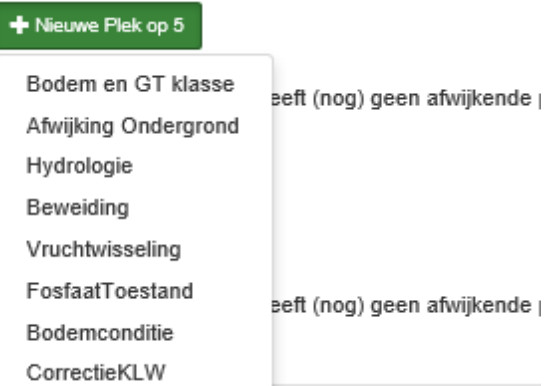

- Klik op het vak rechts naast "Oppervlak (ha)" en vul het oppervlak in van de afwijkende plek (in ha).

\section{Nieuw}

Afwijkende plek bodem

Oppervlak (ha)

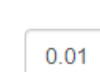


- Klik op het dropdown menu rechts van "Grondwater Trap" en kies de optie die het best de afwijkende plek karakteriseert.

\section{Nieuw}

Afwijkende plek bodem

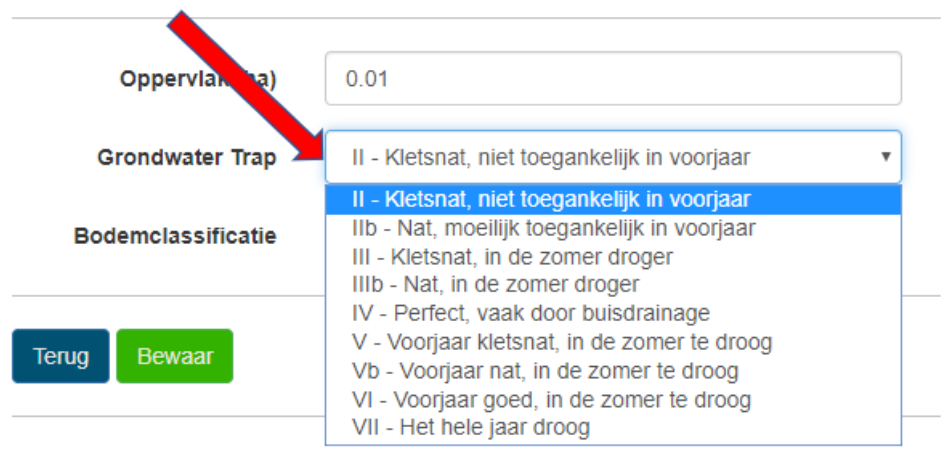

- Klik op het dropdown menu rechts van "Bodemclassificatie" en kies de optie die het best de afwijkende plek karakteriseert.

\section{Nieuw}

Afwijkende plek bodem

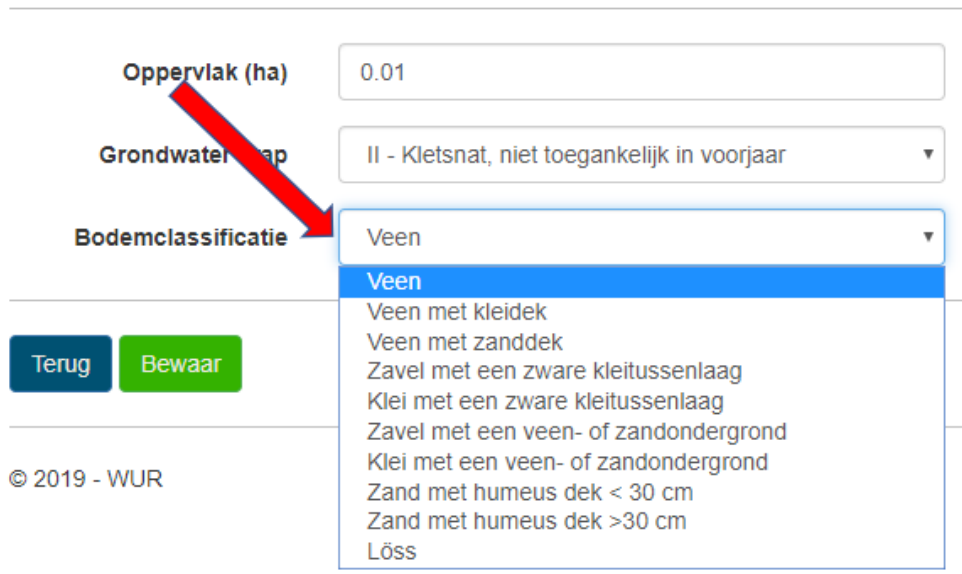

\section{Thema: 'Afwijkende Ondergrond'}

- Klik op het Thema 'Afwijkende ondergrond'. Het scherm voor het karakteriseren van de "Afwijkende plek bodemprofiel" verschijnt.

1. Klik op het vak rechts naast "Oppervlak (ha)" en vul het oppervlak in van de afwijkende plek (in ha).

2. Kies welke omschrijving het beste past bij de afwijkende plek in de ondergrond en vink aan.

$\checkmark \quad$ 'Lichte minerale laag' als er een zandlaag zit op een diepte van meer dan $120 \mathrm{~cm}$ onder maaiveld.

$\checkmark \quad$ 'Diepe, lichte minerale laag' als er een zandlaag zit tot aan $120 \mathrm{~cm}$ onder maaiveld.

$\checkmark \quad$ 'Slecht doorlatende laag' als het gaat om een slecht doorlatende laag van wat voor materiaal dan ook.

3. Klik op 'Terug' indien er toch geen afwijkende plek is of u zich heeft vergist. 


\section{Nieuw}

Afwijkende plek bodemprofiel

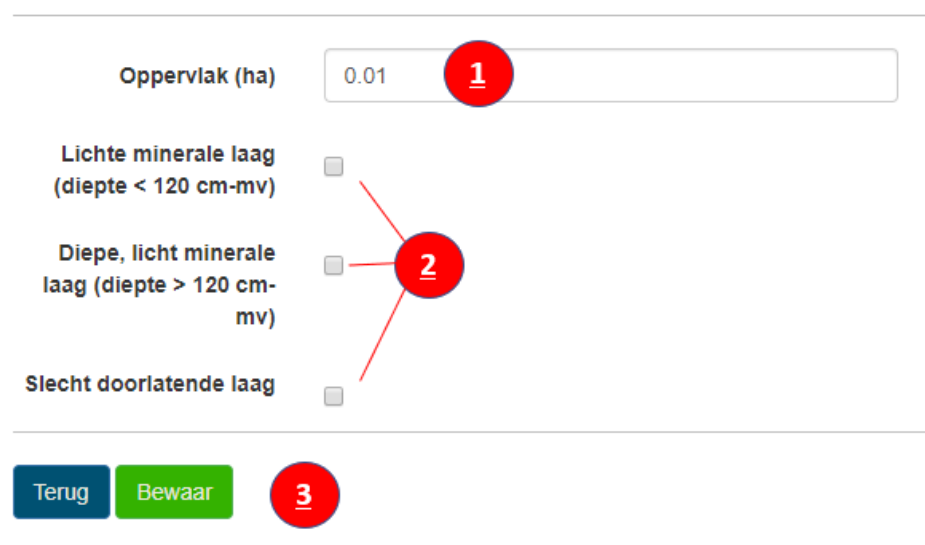

Thema: 'Hydrologie'

- Klik op het Thema 'Hydrologie'. Het scherm voor het karakteriseren van de "Afwijkende plek hydrologie" verschijnt.

1. Klik op het vak rechts naast "Oppervlak (ha)" en vul het oppervlak in van de afwijkende plek (in ha).

2. Vink aan of de afwijkende plek greppels bevat ja of nee.

3. Klik op het dropdownmenu rechts naast "Drainage" en kies de beste omschrijving bij de situatie van de afwijkende plek. Standaard is op de afwijkende plek 'Geen' drainage geselecteerd.

4. Vink aan of op de afwijkende plek sprake is van kwel ja of nee.

\section{Nieuw}

Afwijkende plek hydrologie

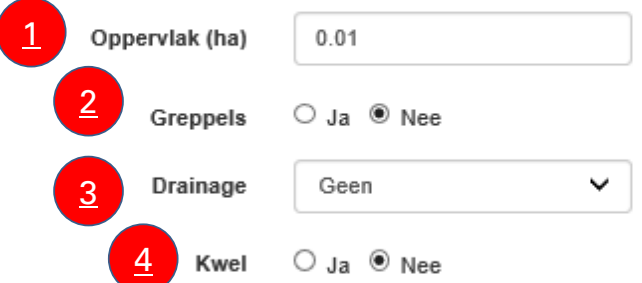

Thema: 'Beweiding'

- Klik op het Thema 'Beweiding'. Het scherm voor het karakteriseren van de "Afwijkende plek beweiding" verschijnt.

1. Klik op het vak rechts naast "Oppervlak (ha)" en vul het oppervlak in van de afwijkende plek (in ha).

2. Klik op het vak rechts naast "Beweidingssysteem" en kies het beweidingssysteem wat het best bij de afwijkende plek past.

3. Klik op het vak rechts naast "Opstallen" en kies het moment van opstallen wat het best bij de afwijkende plek past. 


\section{Nieuw}

Afwijkende plek beweiding

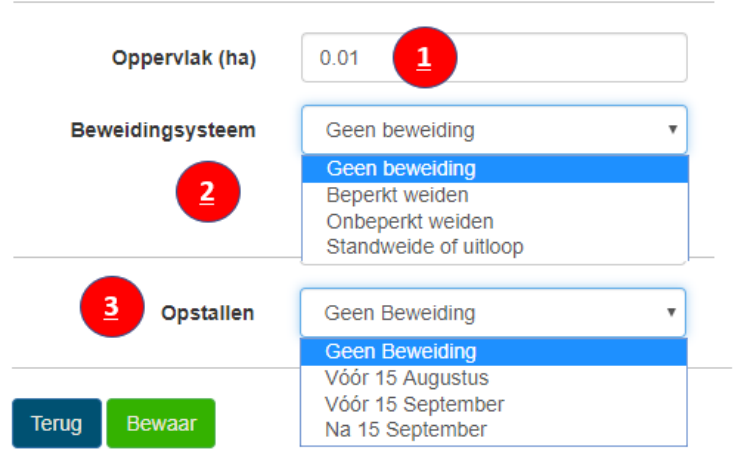

\section{Thema: 'Vruchtwisseling'}

- Klik op het Thema 'Vruchtwisseling'. Het scherm voor het karakteriseren van de "Afwijkende plek vruchtwisseling" verschijnt.

1. Klik op het vak rechts naast "Oppervlak (ha)" en vul het oppervlak in van de afwijkende plek (in ha).

2. Klik op het vak rechts naast "Herinzaai" en kies de frequentie van herinzaai van de afwijkende plek.

3. Klik op het vak rechts naast "Vruchtwisseling Gras" en kies het vruchtwisselingsschema wat het best bij de afwijkende plek past.

\section{Nieuw}

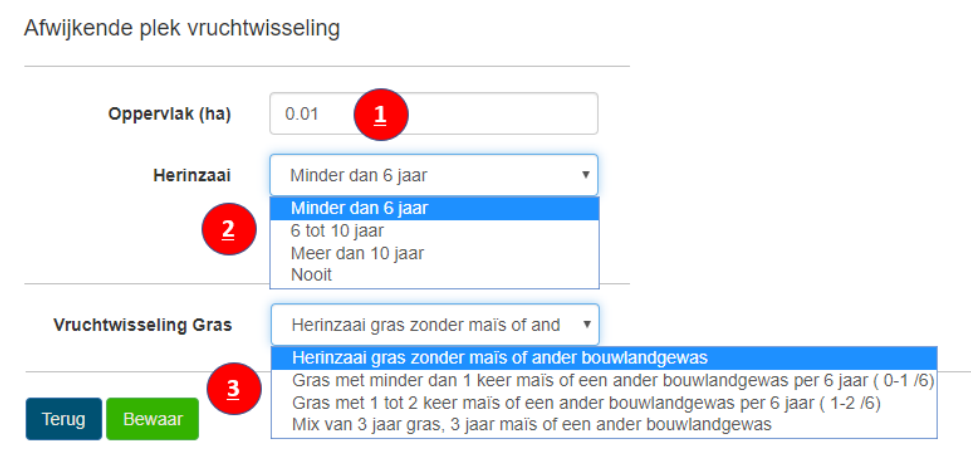

\section{Thema 'FosfaatToestand'}

- Klik op het Thema 'FosfaatToestand". Het scherm voor het karakteriseren van de "Afwijkende plek bemestingshistorie" verschijnt.

1. Klik op het vak rechts naast "Oppervlak (ha)" en vul het oppervlak in van de afwijkende plek (in ha).

2. Klik op het vak rechts naast "P-AL Gras" en kies de P-AL toestand die het best bij de afwijkende plek past.

Nieuw

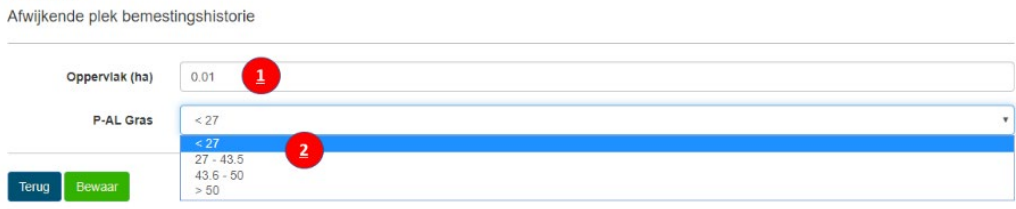




\section{Thema: 'Bodemconditie'}

- Klik op het Thema 'Bodemconditie". Het scherm voor het karakteriseren van de "SpotBodemConditieData" verschijnt.

Aan de Bodemconditie kan een score van 0-49 worden gegeven. Er wordt aan gewerkt om dit Thema te verbeteren.

1. Klik op het vak rechts naast "Oppervlak (ha)" en vul het oppervlak in van de afwijkende plek (in ha).

2. Hier wordt automatisch het tijdstip van invullen weergegeven en hoeft niet te worden gewijzigd.

3. Een score van $0-49$ kan hier worden ingevuld

\section{Nieuw}

SpotBodemConditieData

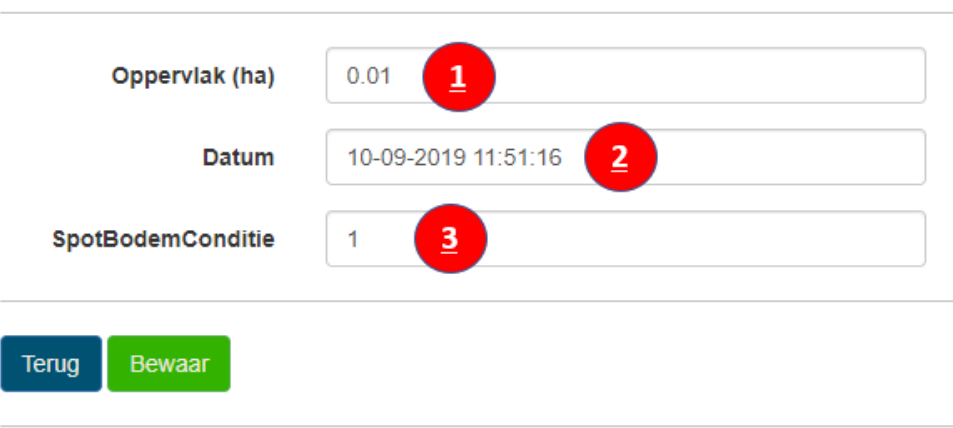

(c) 2019 - WUR

Thema: 'Correctie KLW'

- Klik op het Thema 'CorrectieKLW". Het scherm voor het wijzigen van de "Afwijkende plek ten opzichte van de KringloopWijzer (KLW)" verschijnt.

1. Klik op het vak rechts naast "Oppervlak (ha)" en vul het oppervlak in van de afwijkende plek (in ha).

2. Klik op het vak rechts naast "Afwijking opbrengst" en kies de afwijking van de opbrengst van de afwijkende plek ten opzichte van de rest van het perceel.

3. Klik op het vak rechts naast "Afwijking bemesting" en kies de afwijking van de bemesting van de afwijkende plek ten opzichte van de rest van het perceel.

Naast afwijkende plekken graslandpercelen zijn er ook afwijkende plekken andere percelen.

- Klik op 'Afwijkende plekken andere percelen' in het hoofdscherm van de module "Uitspoeling". Het scherm voor het aangeven van "Afwijkende plekken andere percelen" verschijnt. 


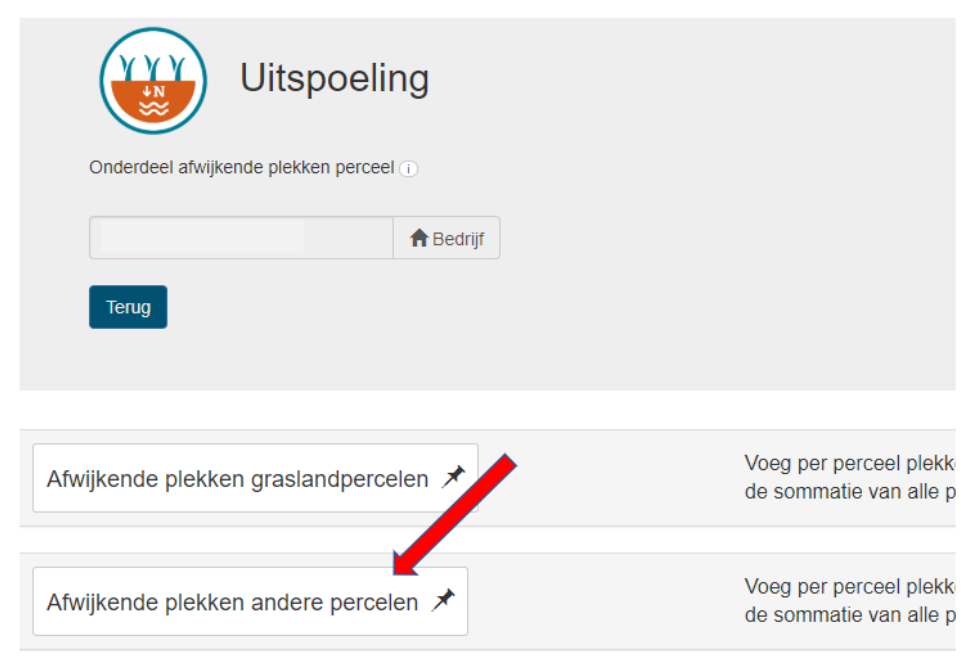

- Een scherm verschijnt met alle andere percelen.

- Ga naar het perceel waarop zich een afwijkende plek bevindt.

- Klik op '+ Nieuwe Plek op <perceelsnaam>'. Een keuzemenu verschijnt.

De beschrijving van Bodemtype, Afwijking Ondergrond, Hydrologie, Bodemconditie en CorrectieKLW zijn gelijk aan de beschrijving van Afwijkende plekken graslandpercelen.

Thema: 'Vanggewas'

- Klik op het Thema 'Vanggewas'. Het scherm "Afwijkende plek vanggewas" verschijnt.

1. Klik op het vak rechts naast "Oppervlak (ha)" en vul het oppervlak in van de afwijkende plek (in ha).

2. Klik op het dropdown menu rechts naast "Zaaidatum Vanggewas" en maak de keuze voor het tijdvak van zaaidatum vanggewas van de afwijkende plek. Indien gekozen wordt voor een tijdvak komen er 2 vervolgvragen.

\section{Nieuw}

Afwijkende plek vanggewas

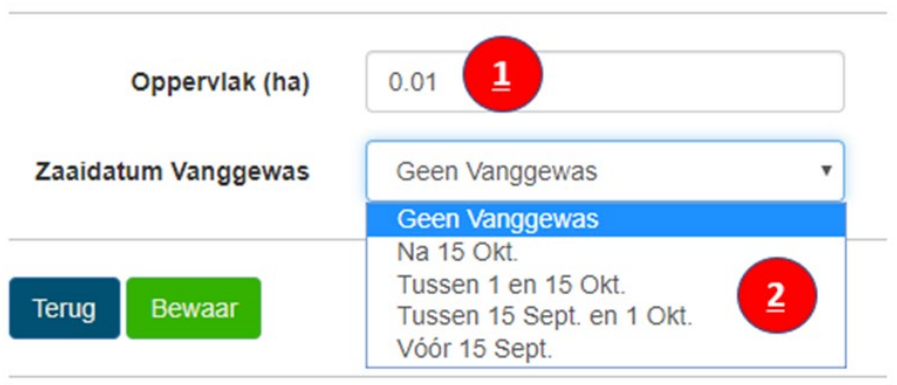

() 2019 - WUR

3. Klik op het dropdown menu rechts naast "Opbrengst Vanggewas" en kies de opbrengst van het vanggewas op de afwijkende plek.

4. Klik op het dropdown menu rechts naast "Onderwerken Vanggewas en kies het tijdvak waarin vanggewas is ondergewerkt op de afwijkende plek. 


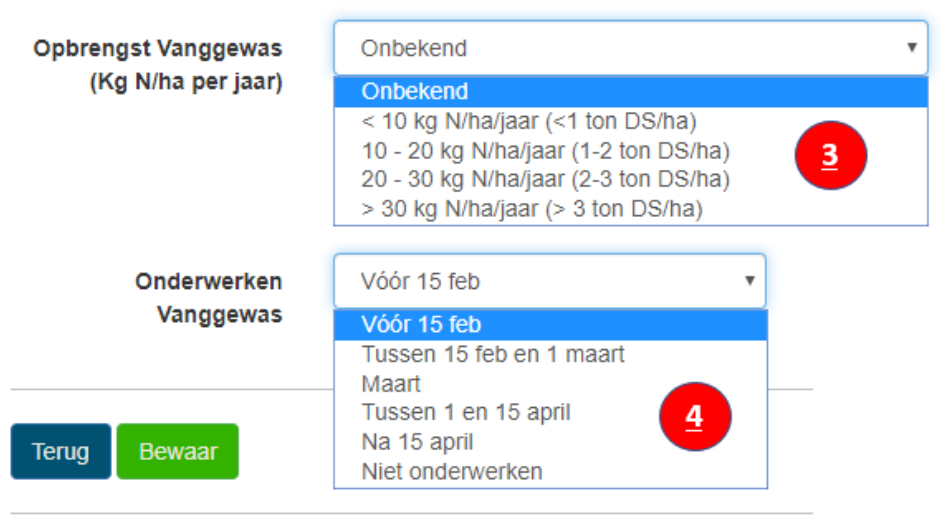

Thema: 'Vruchtwisseling'

- Klik op het Thema 'Vruchtwisseling'. Het scherm "Afwijkende plek vruchtwisseling" verschijnt.

1. Klik op het vak rechts naast "Oppervlak (ha)" en vul het oppervlak in van de afwijkende plek (in ha).

2. Klik op het vak rechts naast "Herinzaai" en kies de frequentie van herinzaai van de afwijkende plek.

3. Klik op het vak rechts naast "Vruchtwisseling Maïs" en kies het vruchtwisselingsschema wat het best bij de afwijkende plek past.

\section{Nieuw}

Afwijkende plek vruchtwisseling

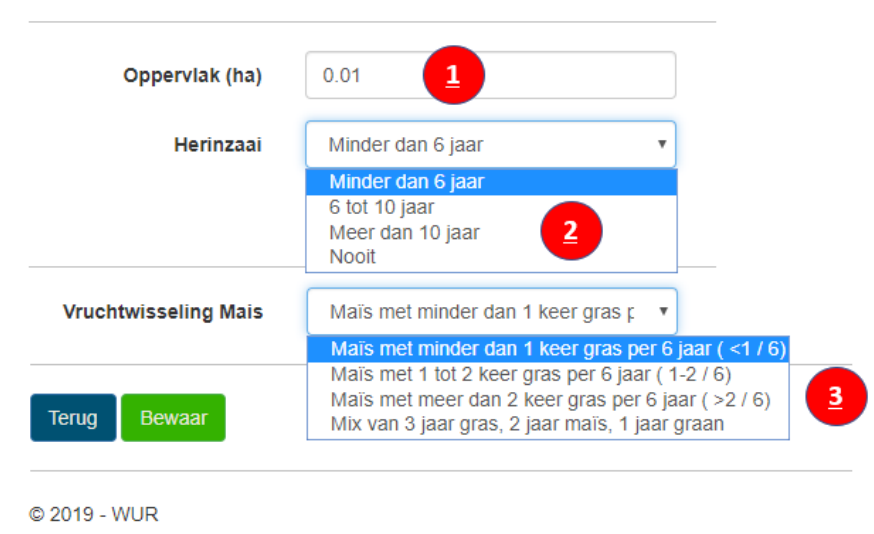

Thema: 'FosfaatToestand'

- Klik op het Thema 'FosfaatToestand'. Het scherm voor het karakteriseren van de "Afwijkende plek bemestingshistorie" verschijnt.

1. Klik op het vak rechts naast "Oppervlak (ha)" en vul het oppervlak in van de afwijkende plek (in ha).

2. Klik op het vak rechts naast "Pw Maïs" en kies de categorie Pw waarde die het best bij de afwijkende plek past. Indien de afwijkende plek apart bemonsterd is, kan de Pw waarde van de bemonsteringsuitslag gebruikt worden.

Alle gegevens zijn nu ingevuld.

- Klik in het Submenu "Uitspoeling; Onderdeel afwijkende plekken perceel” op 'Terug'. Het hoofdmenu van de module "Uitspoeling" verschijnt. 


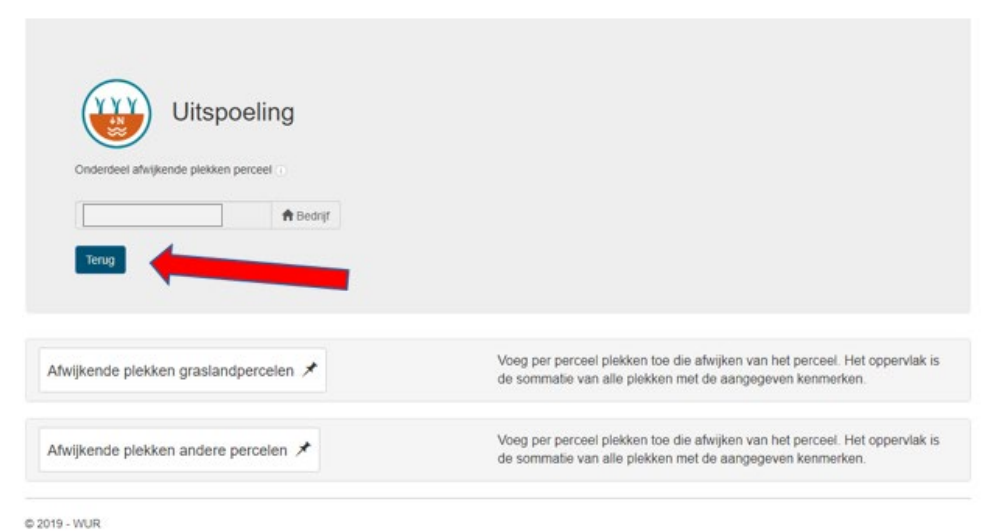

- Klik op 'Volgende Stap: Invoer Module 5 - Afspoeling $\rightarrow$ '. Het openingsscherm van module 5 "Afspoeling" verschijnt.

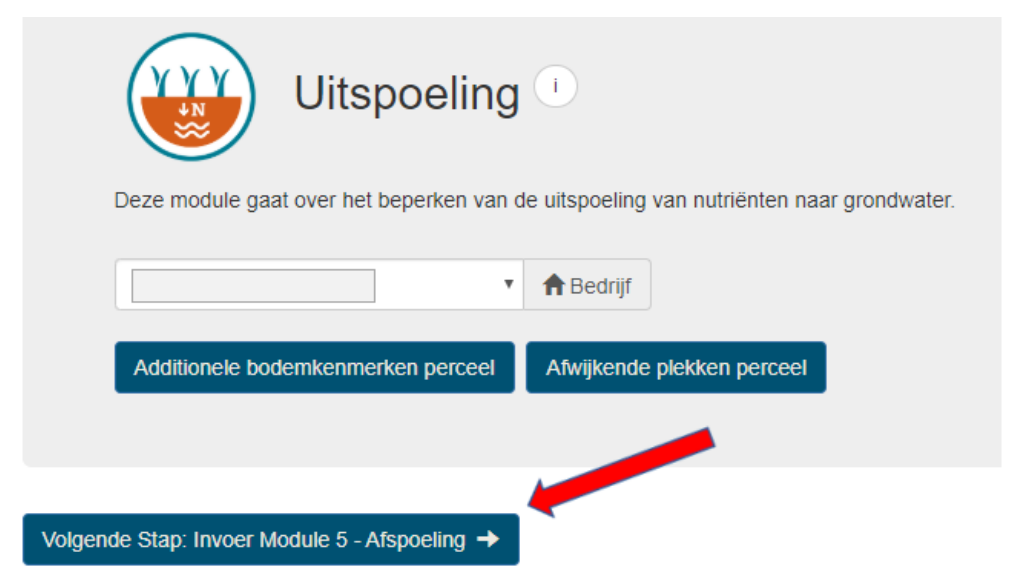

\subsection{Module 5 - Gegevens Afspoeling}

Deze module gaat over het beperken van transport van nutriënten naar het oppervlaktewater. Hiervoor dienen gegevens ingevoerd te worden over de slempgevoeligheid van percelen en de perceelsbemesting. Ook worden in deze module de KLW bedrijfsgegevens mineralen ingelezen.

\section{Perceelsoppervlak - Slemp}

Slemp heeft grote invloed op de afspoeling van het perceel naar de sloot. Om dit te kunnen inschatten zijn extra gegevens nodig als uw percelen heeft met zavel of zand. De invoer van bodemgegevens voor de inschatting van slemp kan gedaan worden voor het hele bedrijf of voor specifieke percelen. Wordt alleen het eerste deel ingevuld, dan gelden deze bodemgegevens voor alle percelen op het bedrijf. Voor individuele percelen kunnen specifieke slempgegevens worden ingevoerd die de bedrijfsspecifieke gegevens overschrijven.

Indien slemp op het bedrijf voorkomt:

- Klik op 'Perceeloppervlak - Slemp'.

- Het scherm "Afspoeling; Slemp" verschijnt. 


\section{A Bedrijfs Water Wijzer 2018 Invoerv Uitvoer- Informatie Contact}

\section{Afspoeling}

Deze module gaat over het beperken van transport van nutriënten naar het oppervlaktewater.

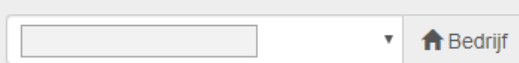

Benodigde gegevens over (klik elk onderdeel):

\section{Perceeloppervlak - Slemp Perceelbemesting KLW bedrijfsgegevens mineralen}

- Klik op 'Terug' indien er toch geen percelen zijn waar last is van slemp of als u zich heeft vergist.

- Klik op 'Bewerk Waarden' om details over slemp in te voeren. Het scherm "Afspoeling, Bedrijfsgegevens voor slempinschatting" verschijnt.

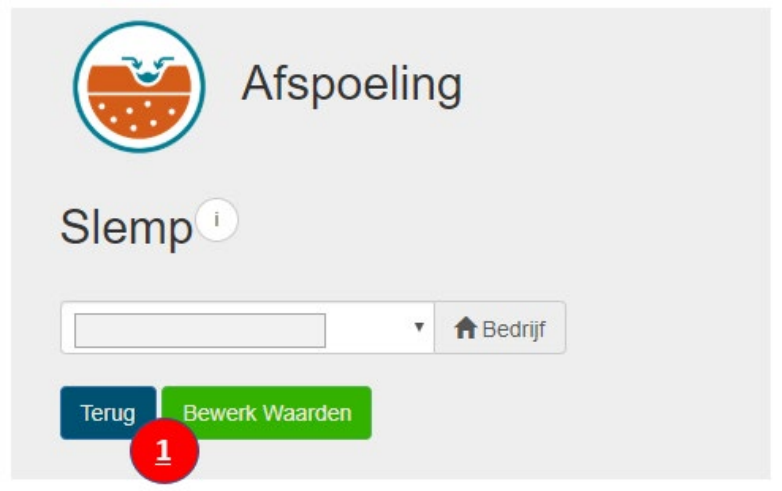

\section{Afspoeling, Bedriifsgegevens voor slempinschatting}

1. Klik op 'Terug' indien besloten wordt toch geen gegevens over slemp te wijzigen.

Klik op 'Bewaar' indien bij onderdeel 1 of 2 gegevens zijn gewijzigd.

2. Kies in het dropdown menu het type materiaal waar de bodem van de percelen uit bestaat. Indien meerdere typen voorkomen dan kiest u voor de meest voorkomende. Afwijkende percelen kunnen ingevuld worden bij optie 3 .

\section{Afspoeling, Perceelspecifieke gegevens voor slempinschatting}

3. Klik op 'Nieuwe Perceelgegevens' als er percelen zijn die afwijken van de meest voorkomende samenstelling. Hier kunnen slempgegevens per perceel gespecificeerd worden indien die percelen afwijken van de bedrijfsgegevens voor slempinschatting.

Een scherm "Perceel-specifieke gegevens voor slempinschatting" met een dropdown menu voor de keuze van een perceel verschijnt. 


\section{Afspoeling} Slemp heeft grote invloed op de afspoeling van het perceel naar de sloot. Om dit te kunnen insci
zand. Deze gegevens kunt u hier invullen voor uw hele bedrijf en voor daarvan afwijkende perce

\section{A Bedrijf}

Terug Bewaar

1

Bedrijfsgegevens voor slempinschatting

Deze gegevens gelden voor uw hele bedrij. Afwijkingen hierop kunt u per perceel hieronder apart invullen

\section{Zand of loss type}

Leemarm zand

\section{Leemarm zand}

Lemig zand

Zandig leem (Löss)

Siltig leem (Löss)

Perceel-specrाтeke gegevens voor slempinschatting

Nieuwe Perceelgegevens

Er zijn nog geen perceel-specifieke gegevens voor slempinschatting gedefinieerd.

1. Perceel-specifieke gegevens voor slempinschatting

Kies een perceel en klik hierop. Het scherm "Create Data Slempgevoeligheid voor: <perceelnaam>" opent zich (in deze test perceel met naam '11 hond')

Perceel-specifieke gegevens voor slempinschatting

\section{Nieuwe Perceelgegevens}

11 hond 1

(๑) 2019 - WUR

1. Maak een keuze voor bodemmateriaal (in dit voorbeeld "Zand type", "Leemarm zand").

2. Klik op 'Terug' als besloten wordt toch geen wijziging aan te brengen in de slempgevoeligheid van het perceel. Er worden geen wijzigingen geregistreerd.

Klik op 'Bewaar' als de wijziging wel opgeslagen moet worden. Het voorgaande scherm "Perceelspecifieke gegevens voor slempinschatting" verschijnt.

Create

Data Slempgevoeligheid voor: 11 hond

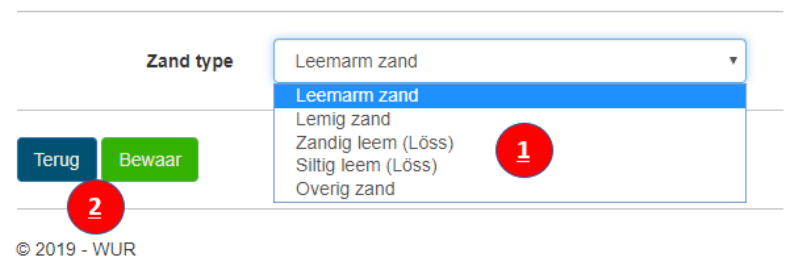


1. Klik op 'Wijzig' indien de gegevens voor slempinschatting gewijzigd moeten worden.

Klik op 'Verwijder' indien de gegevens over slemp voor dat perceel verwijderd moeten worden. Het scherm "Delete, Are you sure you want to delete this?" verschijnt.

Perceel-specifieke gegevens voor slempinschatting

\begin{tabular}{|c|c|c|c|c|c|}
\hline Perceel & Zavel type & Kalk concentratie & Zand of löss type & Opties & \\
\hline 11 hond & & & Zandig leem (Löss) & Wizig & Verwijder \\
\hline
\end{tabular}

1. Klik op 'Terug' indien besloten wordt de gegevens over slemp toch te behouden.

Klik op 'Verwijder' als de gegevens over slemp voor het geselecteerde perceel verwijderd moeten worden.

Het scherm van het sub menu "Afspoeling, Bedrijfsgegevens voor slempinschatting" verschijnt.

\section{Delete}

Are you sure you want to delete this?

DataModule5

\begin{tabular}{|c|c|c|}
\hline \multicolumn{3}{|c|}{ BedrijfsNaam } \\
\hline & PerceeINaam & 11 hond \\
\hline & kOmschrijving & Geen kalk $(<0.5 \%)$ \\
\hline & dOmschrijving & Zandig leem (Löss) \\
\hline & OOmschrijving & Licht \\
\hline Terug & Verwijder & \\
\hline
\end{tabular}

- Klik op 'Bewaar' om de wijzigingen op te slaan. Het scherm "Afspoeling, Slemp" verschijnt.

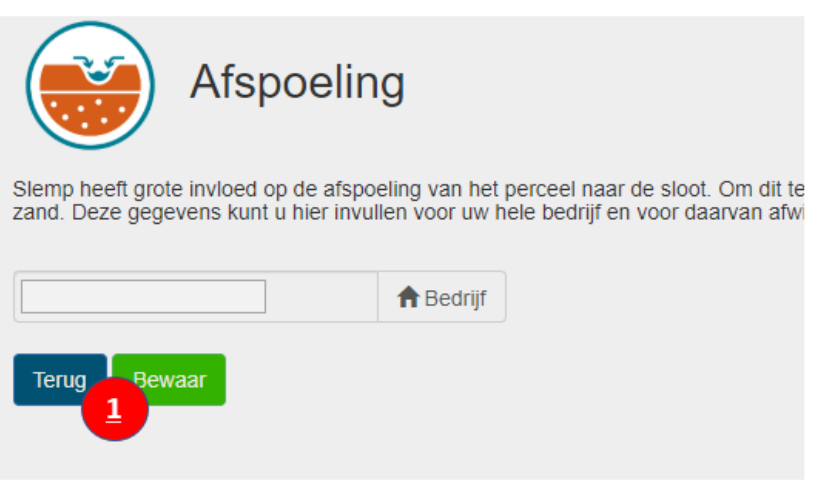

\section{Bedrijfsgegevens voor slempinschatting}

Deze gegevens gelden voor uw hele bedrijf. Afwijkingen hierop kunt u per perceel hieronder

Zand of lös type

Leemarm zand

\section{Perceel-specifieke gegevens voor slempinschatting}


- Klik op 'Terug'. Het beginscherm voor de module "Afspoeling” verschijnt.

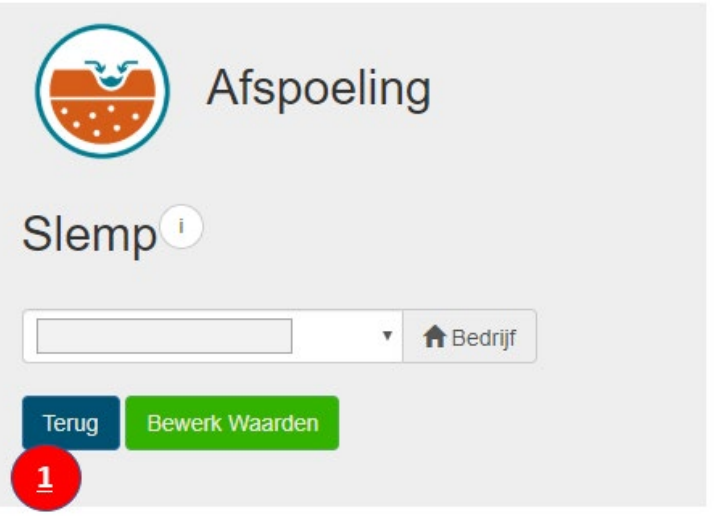

\section{Gegevens Perceelbemesting}

Om de perceelbemesting in te voeren is het handig om de percelen in te delen in groepen met een gelijke of bijna gelijke bemestingsstrategie. Standaard staan alle percelen in de groep "Overig". Na het aanmaken van groepen, kunnen percelen aan groepen toegevoegd worden. Vervolgens wordt per groep een bemestingsstrategie bepaald. Percelen die niet aan een bepaalde groep zijn toegevoegd blijven in de groep "Overig". In de groep "Overig" kan dan aan elk individueel perceel een bemestingsstrategie worden toegekend.

- Klik op 'Perceelbemesting'. Het scherm "Afspoeling, Perceelgroepen” verschijnt.

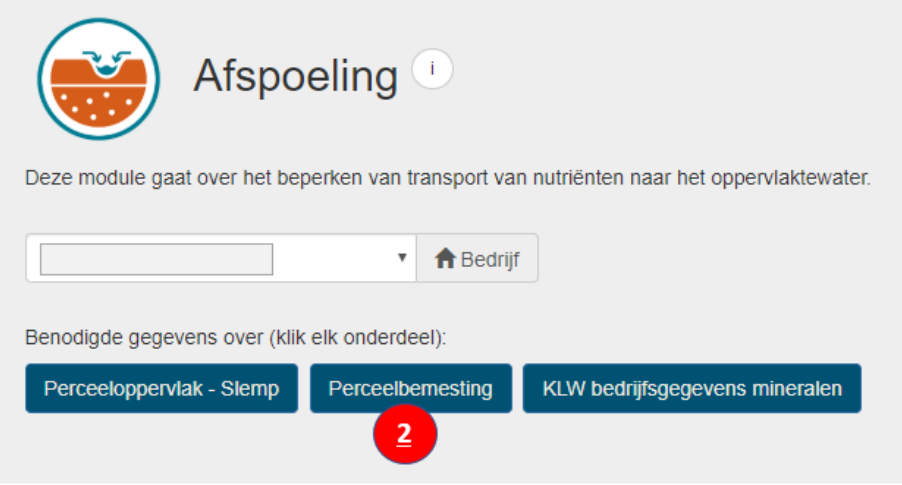

In de afbeelding "Afspoeling, Perceelgroepen" wordt een bedrijf weergegeven dat 1 groep overige percelen en 3 benoemde groepen heeft. We laten zien hoe een groep toegevoegd, gewijzigd en verwijderd wordt.

- Klik op '+ Nieuwe Perceelgroep' om een nieuwe groep percelen aan te maken. Het scherm "Nieuw, Perceelgroep" verschijnt. 


\section{Afspoeling}

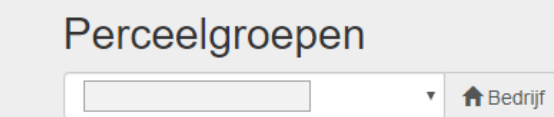

\begin{tabular}{|c|c|c|c|c|}
\hline Terug & — Nieuwe Perceelgroep & Deel de percelen in $\rightarrow$ & \multicolumn{2}{|c|}{ Invoer bemestingen $\rightarrow$} \\
\hline GroepNaam & & & Opties & \\
\hline Overige Percelen & & & Basisgroep & \\
\hline Gras & & & Wijzig & 嗢 Verwijder \\
\hline Snijmais & & & $\sim$ wijig & 畐 Verwijder \\
\hline Gerst & & & Wijzig & 畐 Verwijder \\
\hline
\end{tabular}

อ 2019 - WUR

1. Klik in het vak rechts van "GroepNaam" en geef de naam van een nieuwe groep; dit kan elke gewenste tekst zijn.

2. Klik op 'Terug' als toch geen nieuwe perceelgroep gemaakt hoeft te worden en niets wil bewaren. Kies 'Bewaar' om de nieuwe "GroepNaam" op te slaan.

3. om de nieuwe "GroepNaam" op te slaan.

Bij beide keuzes keert u terug in het voorgaande scherm "Afspoeling, Perceelgroepen".

\section{Nieuw}

Perceelgroep

GroepNaam

Grasland Beheer

\section{Terug Bewaar}

2

(๑) 2019 - WUR

1. De groep "Grasland Beheer" is toegevoegd.

2. Klik op 'Wijzig' of 'Verwijder' om een GroepNaam te wijzigen of een Groep te verwijderen Wordt een GroepNaam gewijzigd, dan volgt eenzelfde procedure als beschreven bij Afspoeling, Slemp (in dit voorbeeld is de GroepNaam "Gras" gewijzigd in "Gras Productie".

Wordt een GroepNaam verwijderd, dan volgt het scherm "Verwijderen, Weet u zeker dat u deze groep wilt verwijderen?" 


\begin{tabular}{|c|c|c|}
\hline GroepNaam & Opties & \\
\hline Overige Percelen & Basisgroep & \\
\hline Gras & Wizig & 音 Verwijder \\
\hline Snijmais & $/$ Wizig & 兽 Verwijder \\
\hline Gerst & Wizig & 畺 Verwijder \\
\hline Grasland Beheer & N Wizig & 畺 Verwijder \\
\hline
\end{tabular}

1. Klik op 'Terug' als besloten wordt toch geen GroepNaam te verwijderen. Klik op 'Verwijder' als de GroepNaam wel verwijderd moet worden.

Bij beide keuzes keert u terug in het voorgaande scherm "Afspoeling, Perceelgroepen".

\section{Verwijderen}

Weet u zeker dat u deze groep wilt verwijderen?

De 2 percelen die in deze groep zaten worden aan de basisgroep toegevoegd. Eventuele bemestingen voor deze groep worden verwijderd.

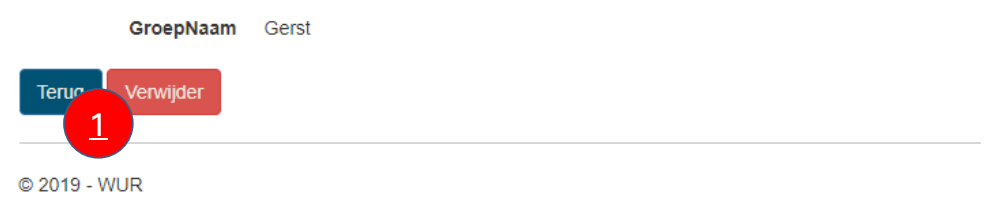

Nadat er groepen zijn aangemaakt, kunnen de percelen die een gelijke of bijna gelijke bemestingsstrategie hebben, aan de verschillende groepen toegekend worden.

- Klik op 'Deel de percelen in $\rightarrow$ '. Het scherm "Indeling in Groepen" verschijnt.

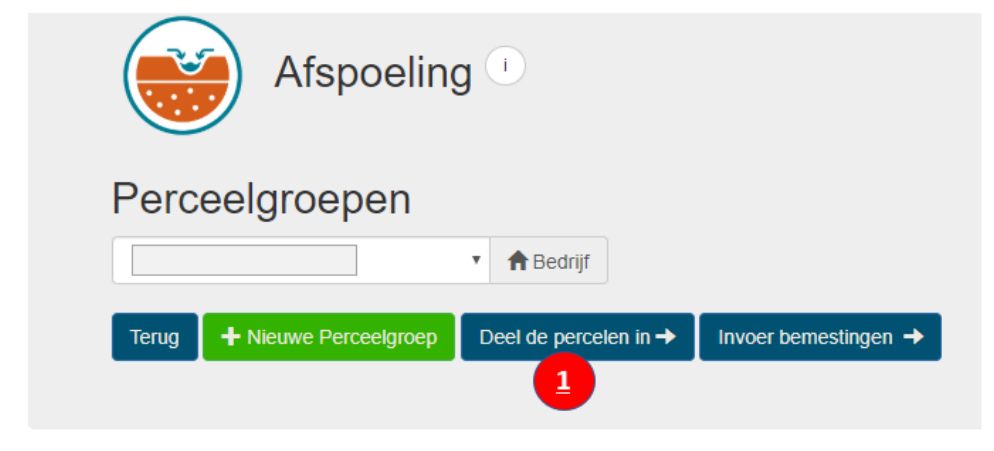

- Klik voor elk perceel het bolletje aan in de juiste kolom. In de grijze balk staat de omschrijving per groep.

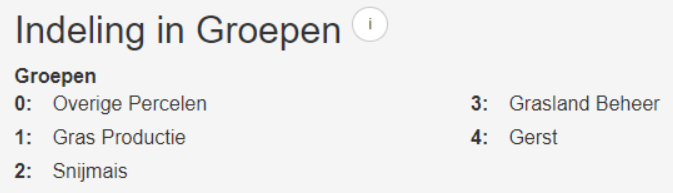


- Klik op 'Terug' als besloten wordt geen indeling in groepen te maken.

- Klik op 'Bewaar' als de indeling in groepen opgeslagen kan worden.

Bij beide keuzes wordt teruggekeerd naar het voorgaande scherm "Afspoeling, Perceelgroepen".

$\begin{array}{llllll}\text { weteringkamp start } & 0: \odot & 1: \odot & 2: \bigcirc & 3: \odot & 4: \bigcirc \\ \text { weteringkamp v zuilen } & 0: \odot & 1: \odot & 2: \odot & 3: \odot & 4: \bigcirc\end{array}$

\section{Terug Bewaar}

- Klik op 'Invoer bemestingen $\rightarrow$ '. Het scherm "Overzicht Bemestingen" verschijnt.

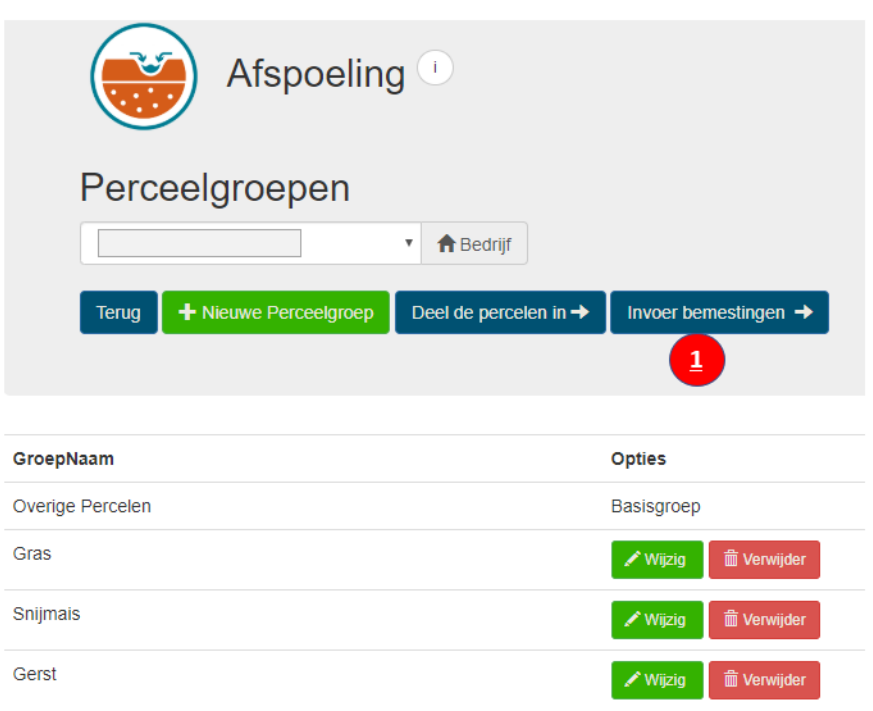

1. Klik op 'Terug naar Definitie Perceelgroepen' als "Invoer bemestingen" niet wordt gewijzigd. Het scherm "Afspoeling, Perceelgroepen" verschijnt.

2. Klik op 'Terug naar Indeling in Groepen' als percelen in bemestingsgroepen moeten worden ingedeeld of de indeling moet worden gewijzigd.

3. Klik op ' $\forall$ Vul in' (groene knop) om de bemestingen voor de betreffende groep percelen voor de eerste keer in te voeren.

4. Klik op ' $\&$ Wijzig' om eerder ingevoerde gegevens te wijzigen.

5. Klik op ' $\&$ Vul in' (oranje knop). Het invoerscherm "Afspoeling; Edit, PerceelBemesting voor groep Gerst" verschijnt.

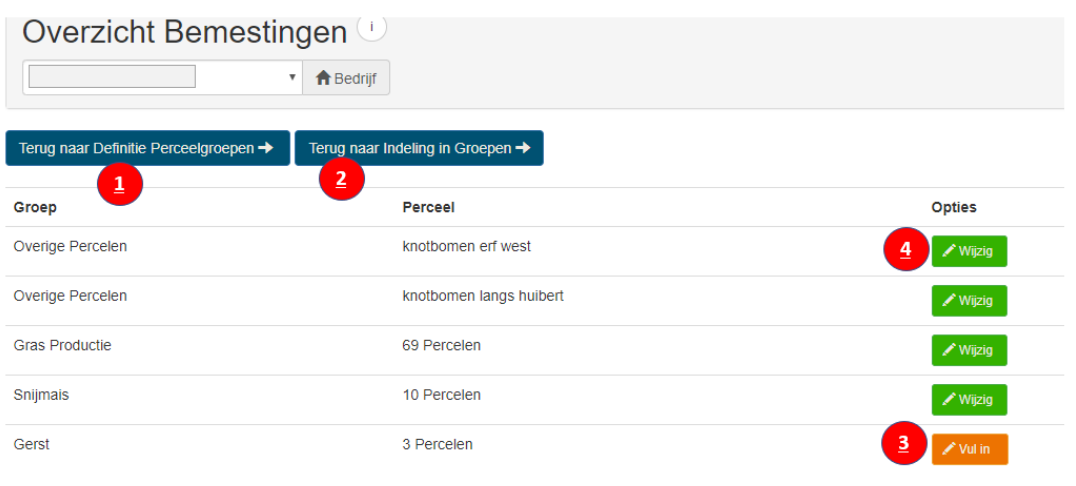

De PerceelBemesting voor groep Gerst (in deze situatie) kan hier volgens onderstaande aanwijzingen worden ingevuld.

1. Kies de maand waarin de betreffende perceelgroep de eerste dierlijke mestgift krijgt.

2. Maak een keuze op welke manier de dierlijke mest wordt toegediend. 
3. Geef aan hoeveel kilogram stikstof wordt toegediend met de eerste dierlijke mestgift (let op: in $\mathrm{N}$ $\mathrm{kg} / \mathrm{ha}$ ).

4. Geef aan hoeveel kilogram fosfaat wordt toegediend met de eerste dierlijke mestgift (let op: in $\mathrm{P}_{2} \mathrm{O}_{5}$ $\mathrm{kg} / \mathrm{ha}$ ).

5. Kies hier de maand waarin de betreffende perceelgroep de eerste kunstmestgift krijgt.

6. Maak een keuze op welke manier de kunstmest wordt toegediend.

7. Geef aan hoeveel kilogram stikstof wordt toegediend met de eerste kunstmestgift (let op: in $\mathrm{N}$ $\mathrm{kg} / \mathrm{ha}$ ).

8. Geef aan hoeveel kilogram fosfaat wordt toegediend met de eerste kunstmestgift (let op: in $\mathrm{P}_{2} \mathrm{O}_{5}$ $\mathrm{kg} / \mathrm{ha}$ ).

9. Kies hier de maand waarin de betreffende gewasgroep de laatste dierlijke mestgift krijgt.

10. Maak een keuze op welke manier de dierlijke mest wordt toegediend.

11. Geef aan hoeveel kilogram stikstof wordt toegediend met de laatste dierlijke mestgift (let op: in $\mathrm{N}$ $\mathrm{kg} / \mathrm{ha})$.

12. Geef aan hoeveel kilogram fosfaat wordt toegediend met de laatste dierlijke mestgift (let op: in $\mathrm{P}_{2} \mathrm{O}_{5} \mathrm{~kg} / \mathrm{ha}$ ).

13. Kies hier de maand waarin de betreffende gewasgroep de laatste kunstmestgift krijgt.

14. Maak een keuze op welke manier de kunstmest wordt toegediend.

15. Geef aan hoeveel kilogram stikstof wordt toegediend met de laatste kunstmestgift (let op: in $\mathrm{N}$ $\mathrm{kg} / \mathrm{ha!})$.

16. Geef aan hoeveel kilogram fosfaat wordt toegediend met de laatste kunstmestgift (let op: in $\mathrm{P}_{2} \mathrm{O}_{5}$ $\mathrm{kg} / \mathrm{ha}$ ).

17. Klik op 'Terug' als besloten wordt de gegevens toch niet te bewaren. Het scherm "Overzicht Bemestingen" verschijnt zonder iets te bewaren.

Klik op 'Bewaar' om de ingevoerde gegevens te bewaren. Het scherm "Overzicht Bemestingen" verschijnt.

\section{Edit}

PerceelBemesting voor groep Gerst

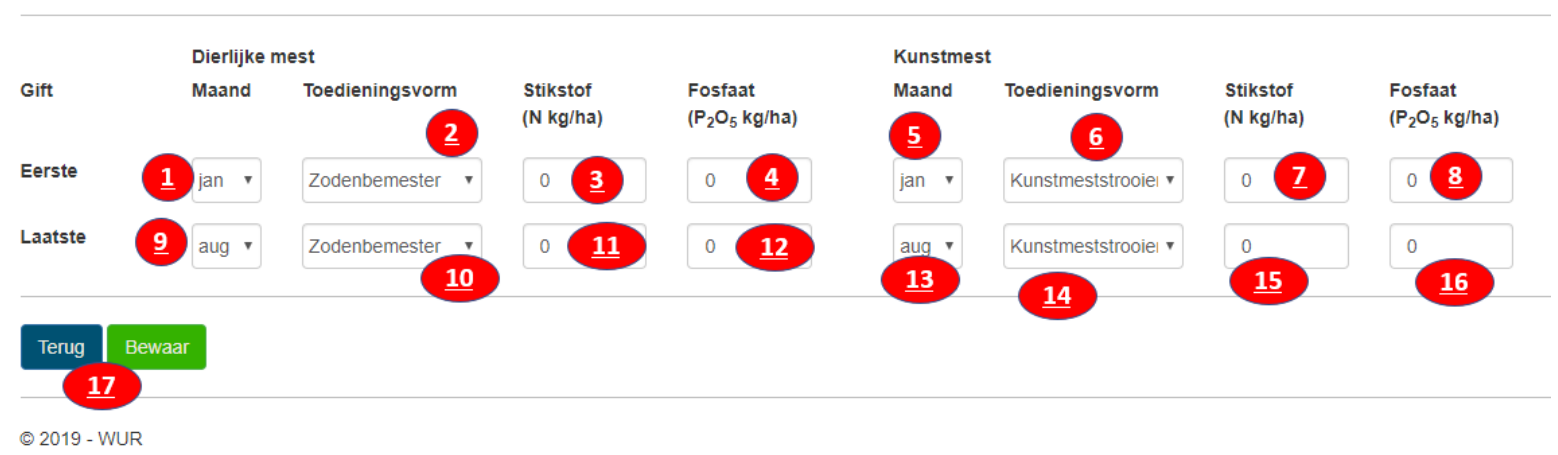

(c) 2019 - WUR

- Klik op ‘Terug naar Definitie Perceelgroepen'. Het scherm “Afspoeling, Perceelgroepen” verschijnt.

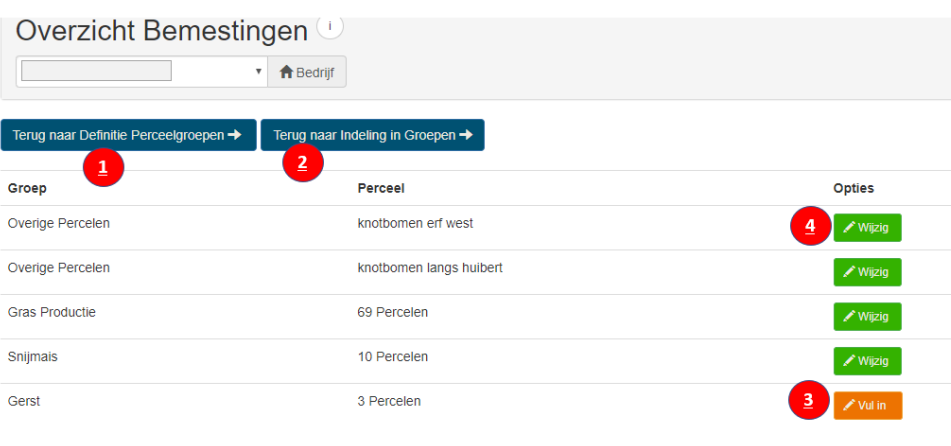


- Klik op 'Terug'. Het hoofdscherm "Afspoeling” verschijnt.

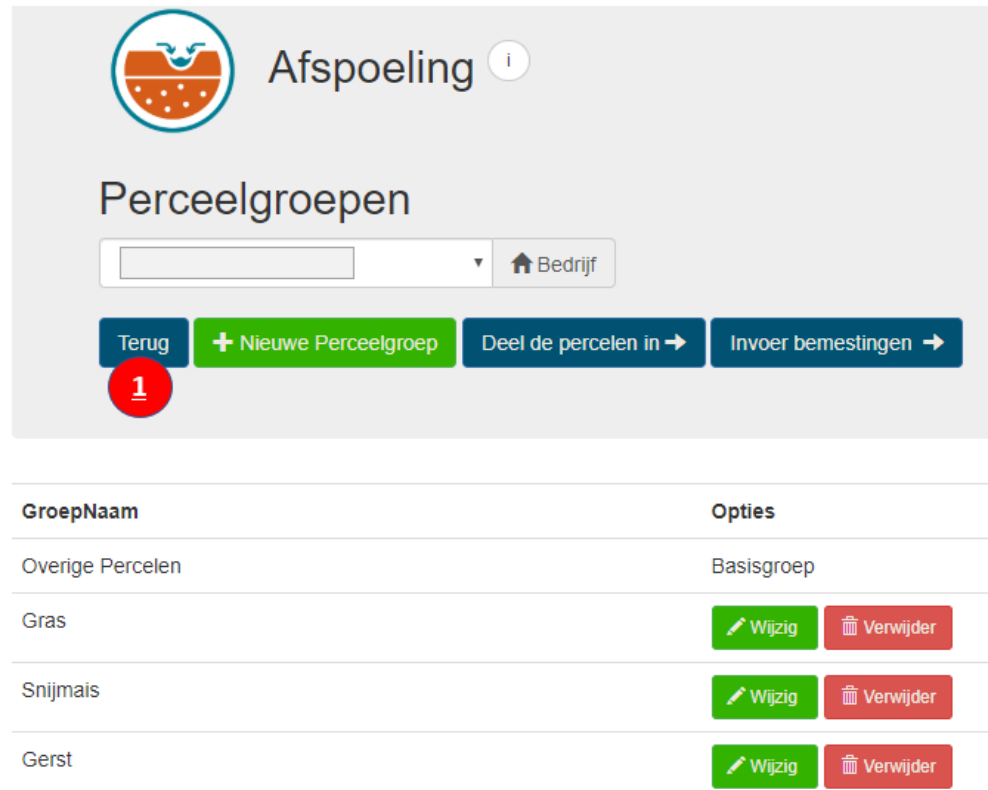

\section{Gegevens KringloopWijzer (KLW)}

Via de output file van de KringloopWijzer worden bedrijfsspecifieke gegevens ingelezen in de BedrijfsWaterWijzer die nodig zijn om de resterende bemestingsgegevens uit te rekenen.

- Klik op 'KLW bedrijfsgegevens mineralen'. Het scherm "Afspoeling, Lees Kringloopwijzer Data Uitvoer Bestand" verschijnt. In dat scherm worden de KLW gegevens ingelezen.

\section{A Bedrifis Water Wizer $\mathbf{2 0 1 8}$ Invoerv Uitvoerv Informatie Contact}

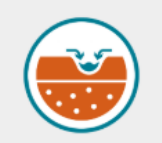

Afspoeling

Deze module gaat over het beperken van transport van nutriënten naar het oppervlaktewater.

- A Bedrijf

Benodigde gegevens over (Klik elk onderdeel):

Perceeloppervlak - Slemp Perceelbemesting

KLW bedrijfsgegevens mineralen 
- Klik op ' $\square$ Blader' rechts naast het invulvak "KLW Uitvoer xml-bestand". Het scherm van Windows verkenner opent. Zoek het KringloopWijzer output bestand op wat eerder op de pc is opgeslagen (zie paragraaf 2.3 waarin het maken van het output bestand wordt beschreven).

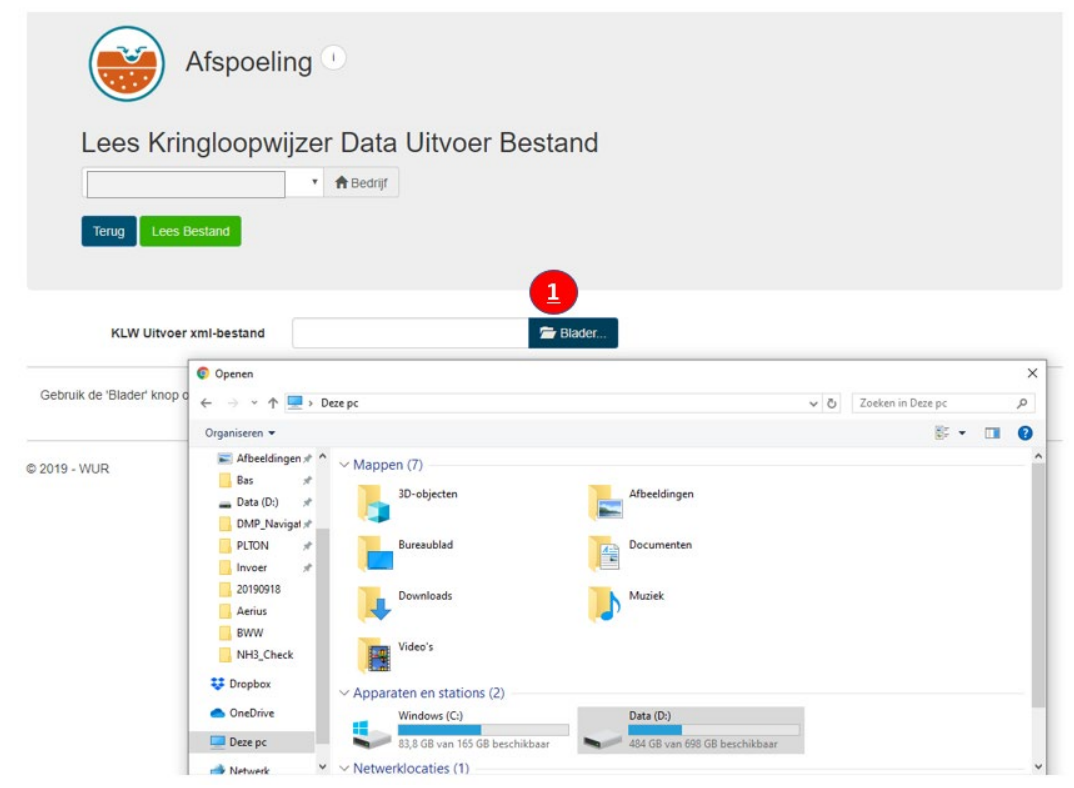

- Selecteer het KringloopWijzer xml bestand.

- Klik op 'Openen'. Het scherm "Afspoeling, Lees Kringloopwijzer Data Uitvoer Bestand” verschijnt.

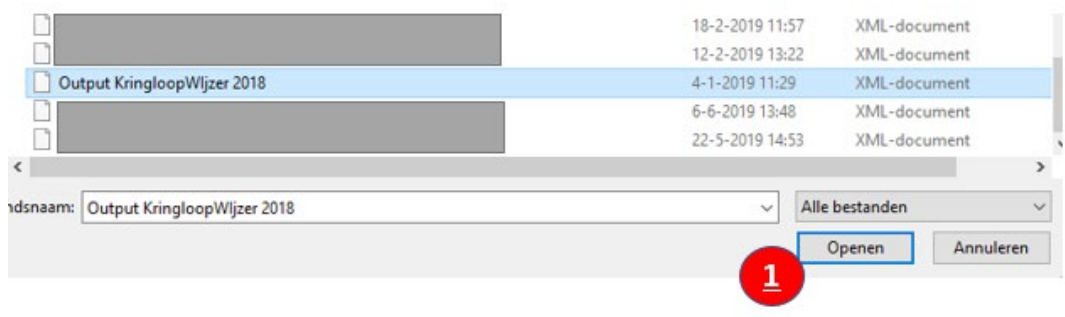

- Klik op Terug' als het KringloopWijzer bestand niet ingelezen hoeft te worden. De gegevens worden niet opgeslagen.

- Klik op 'Lees bestand' om de gegevens uit het bestand van de KringloopWijzer in te lezen. Het scherm met de ingelezen gegevens van de KringloopWijzer verschijnt.

\section{Afspoeling}

\section{Lees Kringloopwijzer Data Uitvoer Bestand

\section{Terug Lees Bestand}


- Klik op 'Terug' als de cijfers niet correct zijn (bijvoorbeeld omdat een verkeerd bestand is aangeklikt).

- Klik op 'Pas toe' als de gegevens wel correct zijn. Het scherm "Afspoeling, Lees Kringloopwijzer Data Uitvoer Bestand" verschijnt.

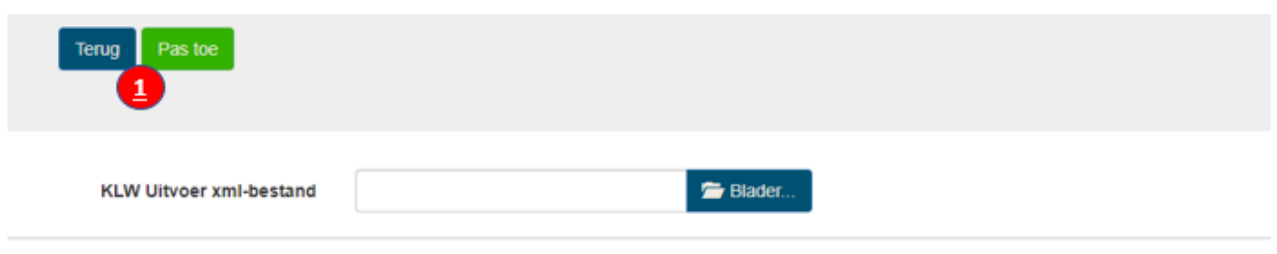

tet xml document lijkt een valide ultwoer van de KringloopWijzer.

\begin{tabular}{|c|c|c|c|c|c|}
\hline N-Bodemoverschot Gras (kg N/ha) & & 212 & & $\mathrm{~N}$-Bodemoverschot Mais (kg N/ha) & 152 \\
\hline P-Bodemoverschot Gras $\left(\mathrm{kg} \mathrm{P} \mathrm{P}_{2} \mathrm{O}_{5} / \mathrm{ha}\right)$ & & 12 & & P-Bodemoverschot Mais $\left(\mathrm{kg} \mathrm{P}_{2} \mathrm{O}_{5} / \mathrm{ha}\right)$ & 14 \\
\hline $\mathrm{N}$-Opbrengst Gras (kg N/ha) & & 323 & & Opbrengst Mais (kg N/ha) & 151 \\
\hline $\mathrm{N}$-bemesting Totaal Gras (kg N/ha) & & 464 & & $\mathrm{~N}$-bemesting Totaal Mais (kg N/ha) & 187 \\
\hline Oppervlak Productiegras (ha) & & 100.96 & & Oppervlak Beheergras (ha) & 0.00 \\
\hline \multirow{2}{*}{ Totaaloppervlak Gras (ha) } & & 100.96 & & P-Bodemoverschot Akker $\left(\mathrm{kg} \mathrm{P}_{2} \mathrm{O}_{5}\right.$ /ha) & -74 \\
\hline & $\begin{array}{l}\text { Productie } \\
\text { gras }\end{array}$ & $\begin{array}{l}\text { Beheer } \\
\text { gras }\end{array}$ & Akker & Mais & \\
\hline $\mathrm{N}$-bemesting (kg N/ha) & 464 & 0 & & & \\
\hline P-bemesting ( $\left.\mathrm{kg} \mathrm{P}_{2} \mathrm{O}_{5} / \mathrm{ha}\right)$ & 96 & 0 & 0 & 62 & \\
\hline Dierlijke mest (ton /ha) & 63 & 0 & & & \\
\hline Dierlijke mest (kg N/ha) & 249 & 0 & 0 & 174 & \\
\hline Dierlijke mest (kg $\left.\mathrm{P}_{2} \mathrm{O}_{5} / \mathrm{ha}\right)$ & 84 & 0 & 0 & 62 & \\
\hline Kunstmest (kg N/ha) & 172 & 0 & 93 & 13 & \\
\hline Kunstmest ( $\left(\mathrm{gg} \mathrm{P}_{2} \mathrm{O}_{5} / \mathrm{ha}\right)$ & 0 & 0 & 0 & 0 & \\
\hline Weidemest (kg N/ha) & 43 & 0 & & & \\
\hline Weidemest $\left(\mathrm{kg} \mathrm{P}_{2} \mathrm{O}_{5} / \mathrm{ha}\right)$ & 12 & 0 & & & \\
\hline Opbrengst ( $\mathrm{kg} \mathrm{P} \mathrm{P}_{2} \mathrm{O}_{5} / \mathrm{ha}$ ) & 84 & 0 & 74 & 48 & \\
\hline
\end{tabular}

In onderstaande afbeelding "Afspoeling, Lees Kringloopwijzer Data Uitvoer Bestand" wordt aangegeven dat er verschil is tussen het totaal perceeloppervlak in de BedrijfsWaterWijzer en het perceeloppervlak in de KringloopWijzer. Dit kan effect hebben op de uitkomsten.

- Klik op 'Terug'. Het startscherm van de module "Afspoeling" verschijnt.

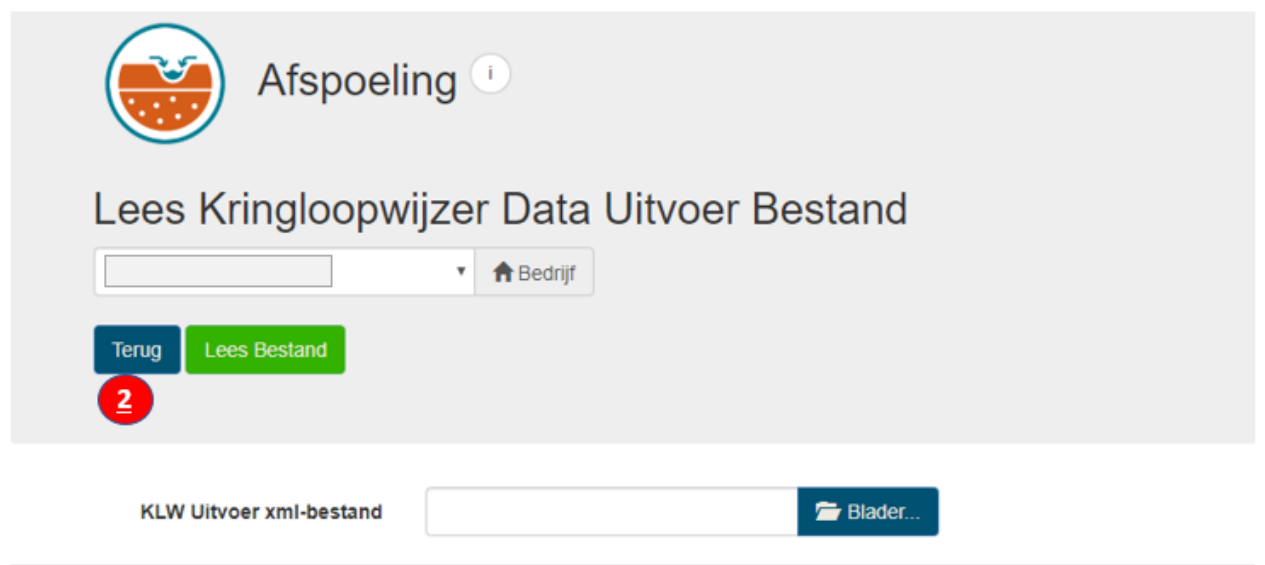

Er is een aanzienlijke mismatch in het totaal oppervlak grasland tussen de BWW ( 101.59 ha) en de Kringloopwijzer ( 100.96 ha). Hierdoor kunnen de afgegeven waarden voor modules 4 en 5 afwijken van de werkelijkheid voor bedrijf:

- Klik op 'Volgende Stap: Invoer Drinkwater $\rightarrow$ '. Het openingsscherm van module 6 "Drinkwater" verschijnt. 


\section{Afspoeling}

Deze module gaat over het beperken van transport van nutrienten naar het oppervlaktewater.

\section{- A Bedrijf}

Benodigde gegevens over (Klik elk onderdeel):

Perceeloppervlak - Slemp Perceelbemesting KLW bedrifssgegevens mineralen

\subsection{Module 6 - Gegevens Drinkwater}

In de BWW worden twee mogelijkheden onderscheiden voor het drenken van het vee: drinken uit drinkbakken of uit de sloot.

1. Beantwoord de vraag: 'Kan vee op uw bedrijf uit de sloot drinken?'.

2. Indien de vorige vraag beantwoord is met "Ja", wordt de knop "Sloten" zichtbaar.

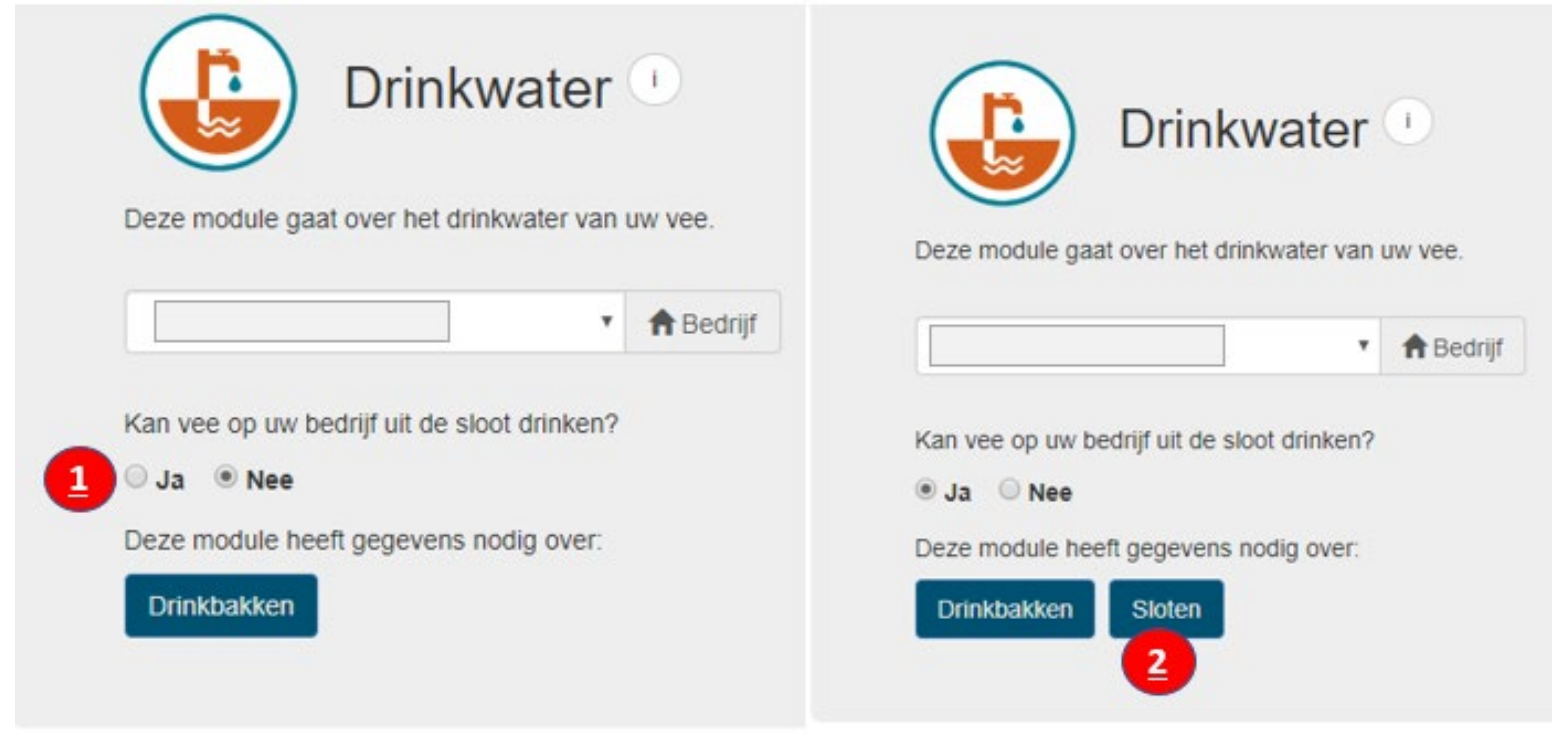

Volgende Stap: Invoer Slootbeheer $\rightarrow$

\section{Drinkbakken - Gegevens drinkbakcheck}

De drinkbakcheck van de GezondheidsDienst levert gegevens op over de samenstelling en daarmee de geschiktheid van het drinkwater voor het vee.

- Klik in het scherm “Drinkwater” op ‘Drinkbakken'. Het scherm “Drinkwater, Drinkbakcheck” verschijnt. 


\section{Drinkwater}

Deze module gaat over het drinkwater van uw vee.

\section{A Bedriif}

Kan vee op uw bedrijf uit de sloot drinken?

- Ja $\bigcirc$ Nee

Deze module heeft gegevens nodig over:

Drinkbakken

Sloten

1

- Klik op 'Terug' als er geen watermonsters van het drinkwater voor het vee beschikbaar zijn.

- Klik op 'Nieuwe Test' als er wel watermonster beschikbaar zijn. Het scherm "Drinkbak Check" met een invulformulier voor het invoeren van de waterkwaliteit verschijnt.

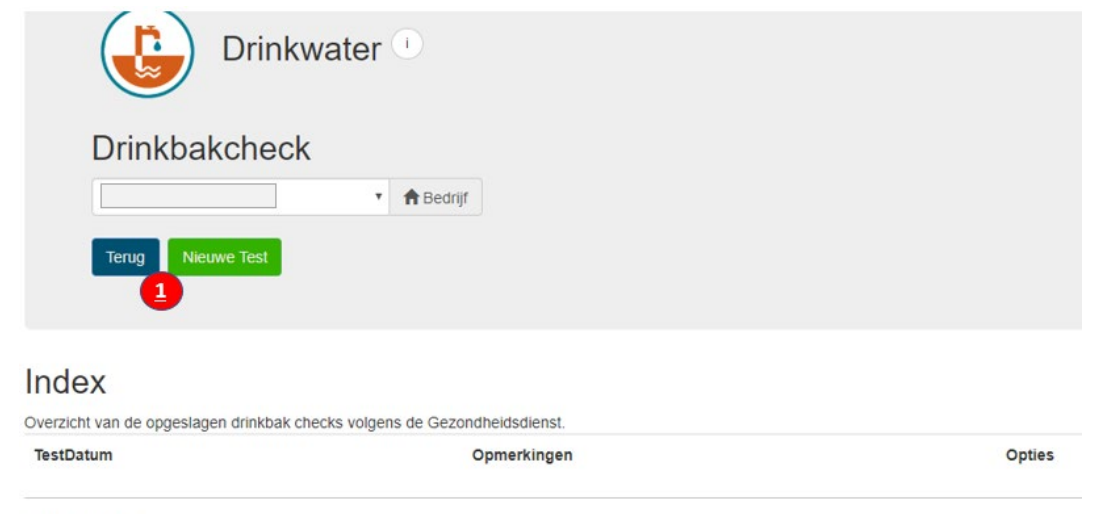

๑ 2019 - WUR

- Klik in het scherm "Drinkbak Check” op 'Terug' als besloten wordt toch geen gegevens in te vullen of te bewaren.

- Indien wateranalyses beschikbaar zijn: Neem in het scherm "Drinkbak Check" de waarden over zoals zijn vermeld op het formulier van de wateranalyse.

- Klik op 'Bewaar'. De ingevoerde gegevens worden opgeslagen. Het scherm "Drinkwater, Drinkbakcheck” verschijnt. 


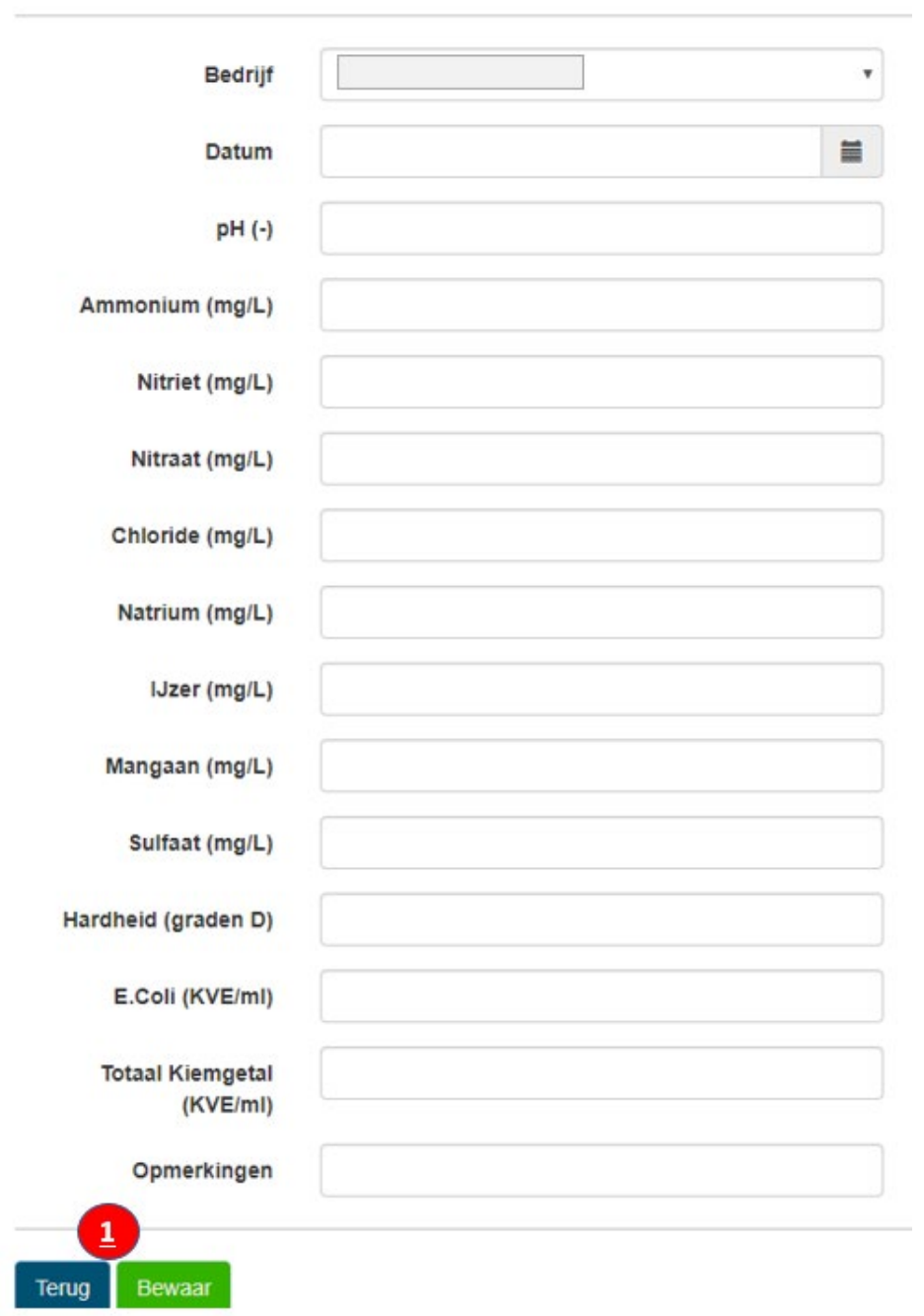

1. Klik in het scherm "Drinkwater, Drinkbakcheck" op 'Terug'. Het hoofdscherm van de module "Drinkwater" verschijnt.

2. Klik op 'Nieuwe Test' om een andere wateranalyse voor het drinkwater toe te voegen. Zie hiervoor voorgaande beschrijving en afbeelding.

3. Klik op 'Wijzig' om eerder ingevoerde gegevens te wijzigen.

4. Klik op 'Details' om de ingevoerde waarden te kunnen inzien. Het scherm "Details, DrinkbakCheckData" verschijnt.

5. Klik op 'Verwijder' om een eerder ingevoerde analyse te verwijderen. Het scherm 'Verwijderen, Weet u zeker dat u dit wilt verwijderen?" verschijnt. 


\section{Drinkwater}

\section{Drinkbakcheck}

\section{- A Bedrijf}

Index

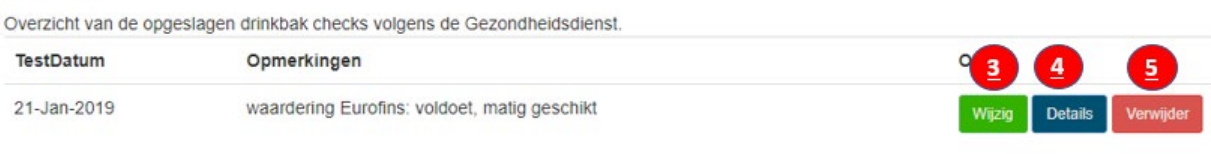

() 2019 - WUR

Het scherm "Details, DrinkbakCheckData":

- Klik in het scherm "Details, DrinkbakCheckData” op 'Terug'. Het voorgaande scherm "Drinkwater, Drinkbakcheck" verschijnt.

- Klik op 'Wijzig' als een waarde aangepast moet worden. Hiervoor verschijnt het scherm "Drinkbak Check". Wijzig een of meerdere waarden en klik op 'Bewaar'. Het scherm "Drinkwater, Drinkbakcheck" verschijnt weer.

\section{Details}

\section{DrinkbakCheckData}

\begin{tabular}{|c|c|}
\hline Bedrijf & \\
\hline Testdatum & 21-Jan-2019 \\
\hline Opmerkingen & waardering Eurofins: voldoet, matig geschikt \\
\hline $\mathrm{pH}(-)$ & 7.50 \\
\hline Ammonium (mg/L) & 0.20 \\
\hline Nitriet (mg/L) & 0.26 \\
\hline Nitraat(mg/L) & 10.00 \\
\hline Chloride(mg/L) & 67.00 \\
\hline Natrium (mg/L) & 43.00 \\
\hline IJzer (mg/L) & 0.29 \\
\hline Mangaan (mg/L) & 0.06 \\
\hline Sulfaat (mg/L) & 1.00 \\
\hline Hardheid (Graden D) & 22.00 \\
\hline E.coli (KVE/ml) & 1 \\
\hline $\begin{array}{r}\text { TotaalKiemgetal } \\
\text { (KVE/ml) }\end{array}$ & 84500 \\
\hline
\end{tabular}

\section{Terug Wijzig \\ $\underline{1}$}

Het scherm "Verwijderen, Weet u zeker dat u dit wilt verwijderen?"

- Klik in het scherm "Verwijderen, Weet u zeker dat u dit wilt verwijderen?" op 'Terug' als de analyse toch niet verwijderd moet worden.

- Klik op 'Verwijder' als de analyse wel verwijderd moet worden.

Bij beide keuzes wordt terug gekeerd naar het voorgaande scherm "Drinkwater, Drinkbakcheck". 


\section{Verwijderen}

Weet u zeker dat u dit wilt verwijderen?

DrinkbakCheckData

Email User

Testdatum 21-Jan-2019

Opmerkingen geen

Wanneer geen analyses meer ingevoerd hoeven te worden en de gegevens juist zijn ingevoerd:

- Klik op 'Terug'. Het hoofdscherm van de module Drinkwater verschijnt.

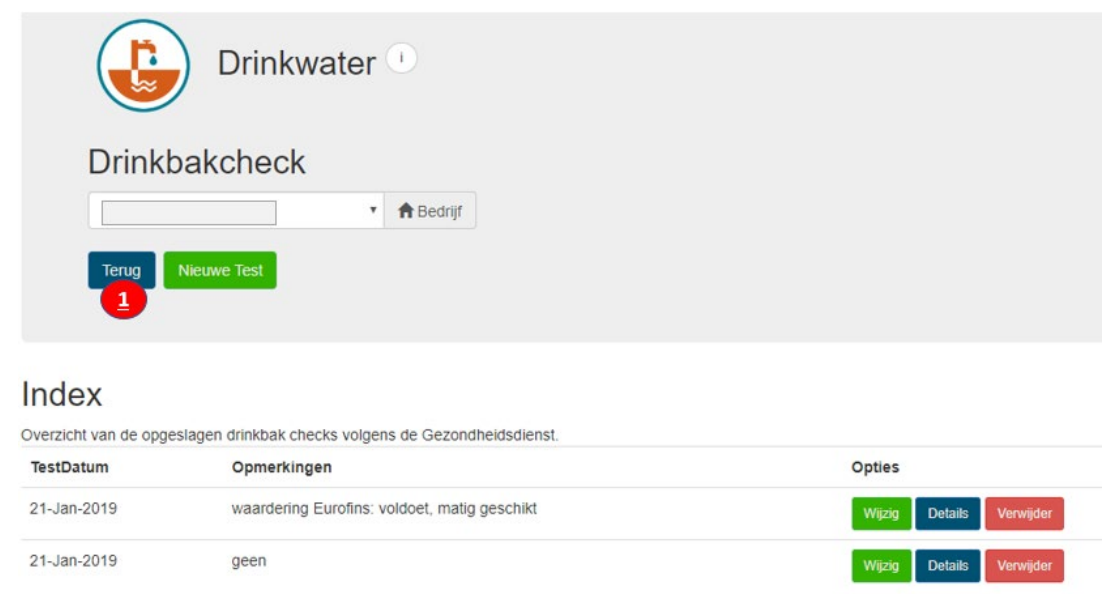

\section{Slootwater - Toets Kaderrichtlijn Water}

De mate van geschiktheid van slootwater voor het drenken van vee kan worden ingeschat aan de hand van de toets Kaderrichtlijn Water.

In dit onderdeel van de module worden gegevens ingevoerd die verkregen zijn door een Doe-Het-Zelf test. De test wordt uitgevoerd aan de hand van richtlijnen. De antwoorden op de vragen zijn meerkeuze antwoorden.

Het Scherm "Slootselectie, (KRW-test) voor bedrijf, Beschikbare sloten voor de Doe-Het-Zelf test."

- Klik op 'Test' achter de sloot waarvoor de resultaten van een uitgevoerde test ingevuld kunnen worden. Het scherm "Doe-het-zelf-test Waterkwaliteit" verschijnt. 


\section{Slootselectie (KRW-test) voor bedrijf \\ $\checkmark \quad$ A Bedrijf}

Beschikbare sloten voor de Doe-Het-Zelf test.

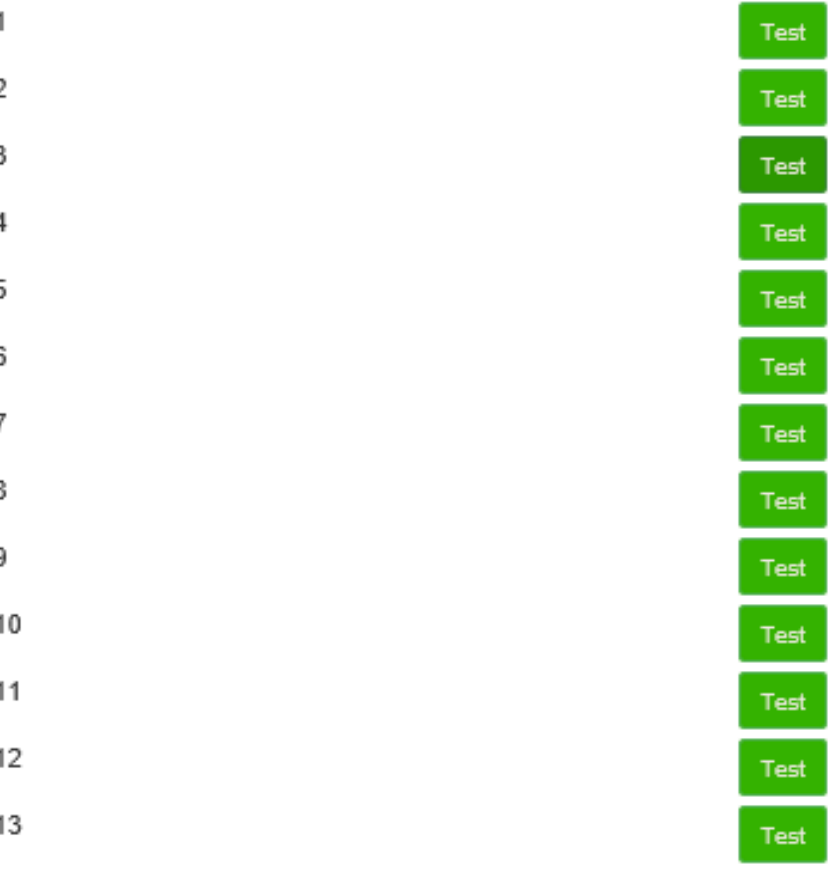

- Klik op 'Opslaan' nadat alle gevraagde gegevens zijn ingevuld. Het scherm "Index, Overzicht van de opgeslagen doe-het-zelf testen volgens de Kaderrichtlijn Water." Verschijnt.

\section{Doe-het-zelf-test Waterkwaliteit}

Sloot: 3

Alleen compleet ingevulde tests kunnen worden opgeslagen. Druk op de button om de test op te slaan.

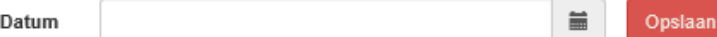

1. Ruikt uw sloot in de weideperiode wel eens naar rotte eieren en/of komen er gasbellen vrij?

Ja $\quad$ Nee

2. Heeft het water in de sloot in de weideoeriode wel eens een rode. oroene of blauwe aloed?

- Klik op 'Terug' als verder geen wijzigingen meer doorgevoerd hoeven te worden, geen details bekeken hoeven te worden of een test verwijderd hoeft te worden. Het hoofdscherm van de module "Drinkwater" verschijnt.

- Klik op 'Bewaar' om de ingevoerde testresultaten te bewaren. Het scherm Na het invullen van de vragen wordt een score berekend. De score wordt telt mee voor het bepalen van het eindresultaat in de BWW.

- Klik op 'Wijzig' om eerder ingevoerde gegevens te wijzigen. Na wijziging klik op ‘Opslaan'. 
- Klik op 'Details' om de resultaten van de ingevulde gegevens en de daarbij behorende score in te zien. Het scherm "Details, Doe-Het-Zelf test resultaten verschijnt" verschijnt.

○ klik in dit scherm op 'Terug'

- Klik op 'Wijzig' als eerder ingevulde gegevens gewijzigd dienen te worden.

- Klik op 'Verwijder' om een eerder ingevulde Doe-Het-Zelf test te verwijderen.

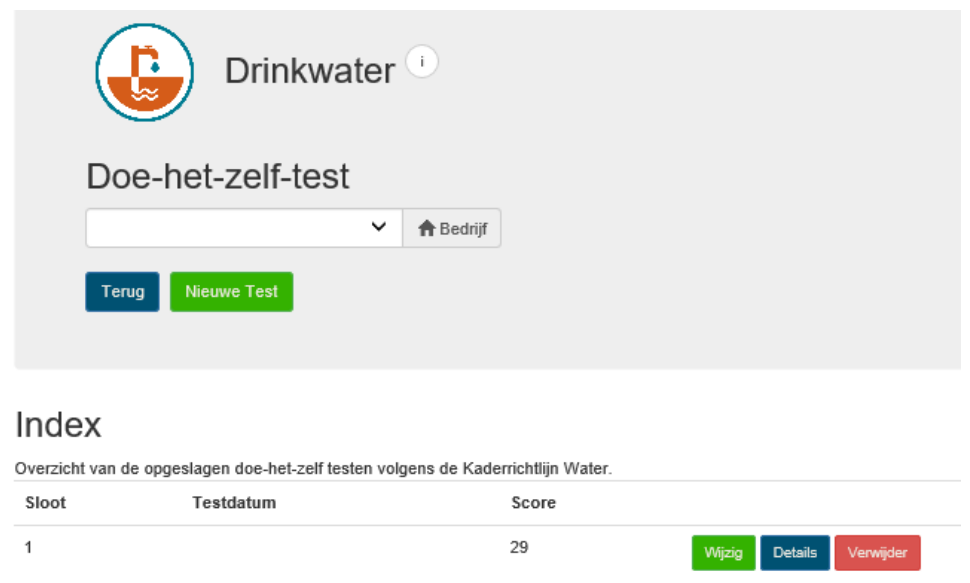

\section{Details}

Doe-Het-Zelf test resultaten.

\begin{tabular}{|c|c|c|}
\hline \multirow{2}{*}{$\begin{array}{l}\text { Sloot naam } \\
\text { Datum }\end{array}$} & \multicolumn{2}{|l|}{1} \\
\hline & $\cdots$ & \\
\hline Vraag & Antw. & Score \\
\hline 1. Geur sloot & B & - \\
\hline 2. Gloed sloot & B & - \\
\hline 3. Kleur monster & $\mathrm{C}$ & 2 \\
\hline 4. Helderheid & $\mathrm{C}$ & 2 \\
\hline 5. Sediment monster & $\mathrm{C}$ & 2 \\
\hline 6. Geur monster & $\mathrm{C}$ & 10 \\
\hline 7. Eendekroos \% & $\mathrm{C}$ & 2 \\
\hline 8. Vreemde instroom & B & 0 \\
\hline 8b. Kwaliteit instroom & B & 0 \\
\hline 9. Waterdiepte & $\mathrm{C}$ & 2 \\
\hline 10. Slib & $\mathrm{C}$ & 2 \\
\hline 11. Stroming & D & 2 \\
\hline 12. Riooloverstort & A & 3 \\
\hline 13. Huishoudelijke lozingen & $\mathrm{C}$ & 2 \\
\hline 14. Erfwater & $\mathrm{C}$ & 2 \\
\hline 15. Grondgebruik naast sloot & B & 2 \\
\hline 16. Zoute kwel & A & 0 \\
\hline 17. Onderbemaling & A & 1 \\
\hline 19. Oeverbegroeiing & A & -1 \\
\hline 20. Waterplanten & A & -1 \\
\hline 21a. Waterjuffers & A & -1 \\
\hline 21b. Kokerjuffers & A & -1 \\
\hline 21c. Slakken & A & -1 \\
\hline Eindscore & & 29 \\
\hline
\end{tabular}


- Klik na invullen module "Drinkwater" op 'Volgende Stap: Invoer Slootbeheer $\rightarrow$ '. Het scherm "Slootbeheer" verschijnt.

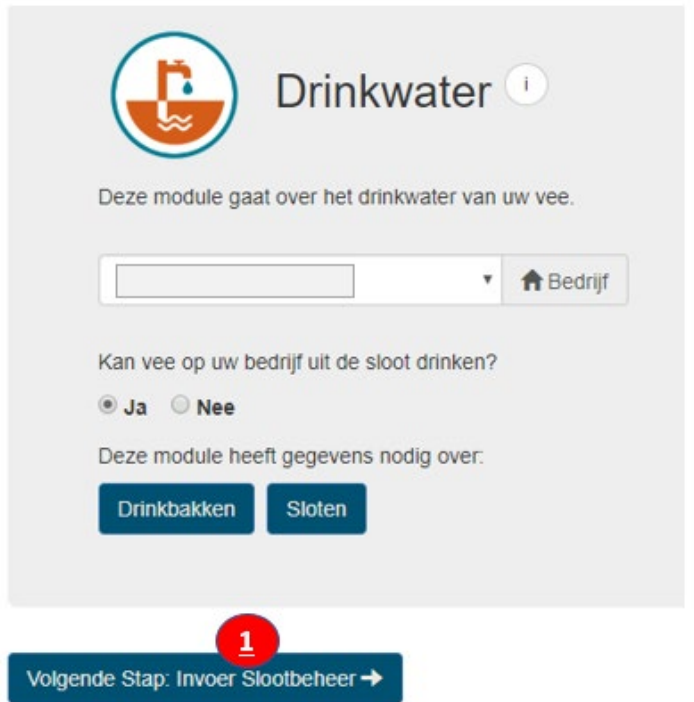

\subsection{Module 7 - Gegevens Slootbeheer}

In deze module wordt gevraagd om een bedrijfsstrategie op te geven voor het schonen van de sloten (maaien en baggeren) op het bedrijf. Als er sloten op het bedrijf zijn die afwijken van de bedrijfsstrategie, dan kunnen deze apart ingevuld worden. Deze gegevens worden dan gebruikt in plaats van de bedrijfsstrategie.

- Klik in het scherm "Slootbeheer" op "Bewerk Waarden. Het scherm "Slootbeheer, Bedrijfsgegevens voor sloot schoning" verschijnt.

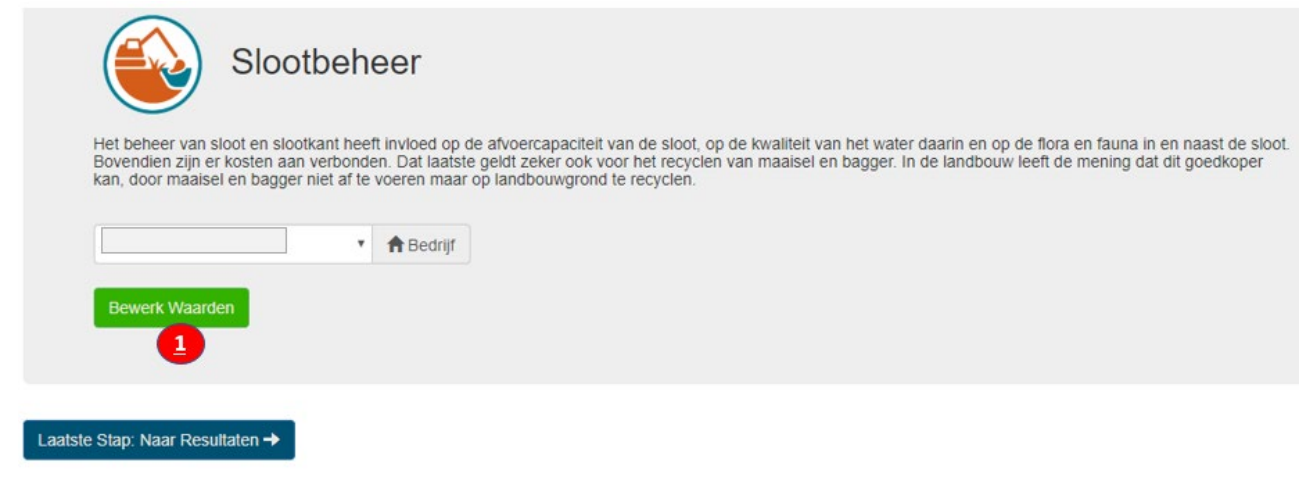

Q 2019 - WUR

Het scherm "Slootbeheer, Bedrijfsgegevens voor sloot schoning".

1. Klik ín het scherm "Slootbeheer, Bedrijfsgegevens voor sloot schoning" op 'Terug'. Het voorgaande scherm "Slootbeheer" verschijnt.

Klik op 'Bewaar' om ingevoerde gegevens of wijziging van gegevens te bewaren.

2. Klik op het dropdown menu onder "Locatie maaisel" en kies de locatie van maaisel die het beste bij het bedrijf past. Onder maaisel worden de gewasresten verstaan die via een maaikorf uit de sloot gehaald worden en gewasresten die door maaien van de taluds ontstaan.

3. Zie procedure bij 2 (Locatie maaisel). Als de methode bij enkele sloten anders gaat, kan dat onder 11 worden ingevuld. 
4. Zie procedure bij 2 (Locatie maaisel). Als de methode bij enkele taluds anders gaat, kan dat onder 11 worden ingevuld. In het keuzemenu wordt ook "ecologisch slootbeheer" genoemd. Met "ecologisch slootbeheer" wordt bedoeld het onderhoud van sloten, rekening houdend met het belang van de biodiversiteit.

Dit wil zeggen dat niet alleen gewerkt wordt aan het behoud van de afvoercapaciteit van de sloot maar ook aan het behoud van flora en fauna in en om de sloot

5. Zie procedure bij 2 (Locatie maaisel). Als de periode bij enkele sloten anders gaat, kan dat onder 11 worden ingevuld.

6. Er kunnen meerdere kwartalen aangevinkt worden.

7. Zie procedure bij 2 (Locatie maaisel). Als het bij enkele sloten anders gaat, kan dat onder 11 worden ingevuld.

8. Zie procedure bij 2 (Locatie maaisel). Als het bij enkele sloten anders gaat, kan dat onder 11 worden ingevuld.

9. Zie procedure bij 2 (Locatie maaisel). Als het bij enkele sloten anders gaat, kan dat onder 11 worden ingevuld.

10. Er kunnen meerdere kwartalen aangevinkt worden.

11. Hier kunnen sloten ingevoerd worden die niet volgens de meest voorkomende wijze worden gemaaid en gebaggerd.

Klik op 'Nieuwe Slootstrategie'. Het scherm "Nieuwe Sloot Schonings Strategie” verschijnt.

\section{Slootbeheer}

Het beheer van sloot en slootkant heeft invloed op de afvoercapaciteit van de sloot, op de kwaliteit van het water daarin en op de flora en fauna in en naast de sloot kan, door maaisel en bagger niet af te voeren maar op landbouwgrond te recyclen.

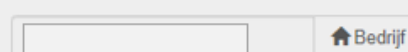

Terug $\mid$ Bewaar

1

\section{Bedrijfsgegevens voor sloot schoning}

Deze gegevens gelden voor uw hele bedrijf. Afvijkingen hierop kunt u per perceel hieronder apart invullen.
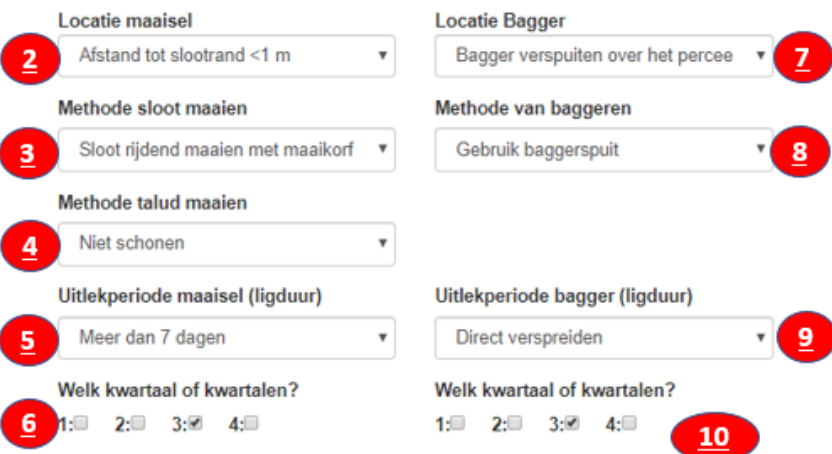
Het scherm "Nieuwe Sloot Schonings Startegie, DataModule 7".

1. Klik rechts van 'Sloot' op het vak voor de keuze van de specifieke sloot waar de locatie van het maaisel en de locatie van de bagger anders is dan 'standaard' ingevoerd in het scherm "Slootbeheer, Bedrijfsgegevens voor sloot schoning".

2. Klik op het dropdown menu onder "Locatie maaisel" en kies de locatie van het maaisel. Let op: een scherm opent met aanvullende vragen.

3. Klik op het dropdown menu onder "Locatie Bagger" en kies de locatie van de bagger. Let op: een scherm opent met aanvullende vragen.

4. Klik op 'Terug' als wordt besloten toch geen nieuwe sloot schonings strategie in te voeren. Klik op 'Bewaar' om de gewijzigde gegevens te bewaren.

\section{Nieuwe Sloot Schonings Strategie}

DataModule7

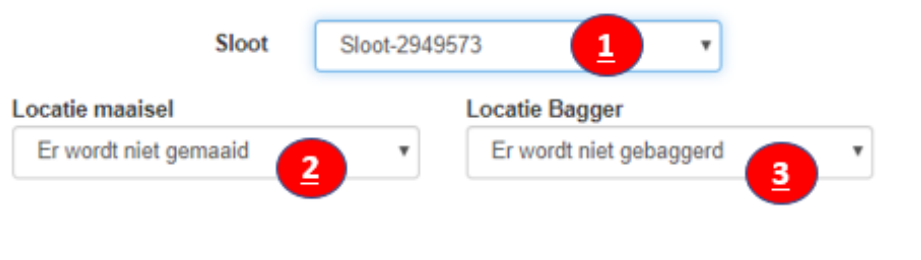

\section{Terug Bewaar}

4

() 2019 - WUR

Aanvullende vragen op het scherm "Nieuwe Sloot Schonings Strategie, DataModule7" voor afwijkende sloten.

De vragen in het blauw gearceerde vlak in de afbeelding openen zich. Het invullen dient te gebeuren zoals in het scherm "Slootbeheer, Bedrijfsgegevens voor sloot schoning".

- Klik op 'Terug' als er toch geen nieuwe sloot schonings strategie voor de geselecteerde sloot ingevuld hoeft te worden.

- Klik op 'Bewaar' om de wijzigingen te bewaren. Het scherm "Sloot-specifieke gegevens (voor afwijkende schoning strategie) verschijnt. 


\section{Nieuwe Sloot Schonings Strategie}

\section{DataModule7}

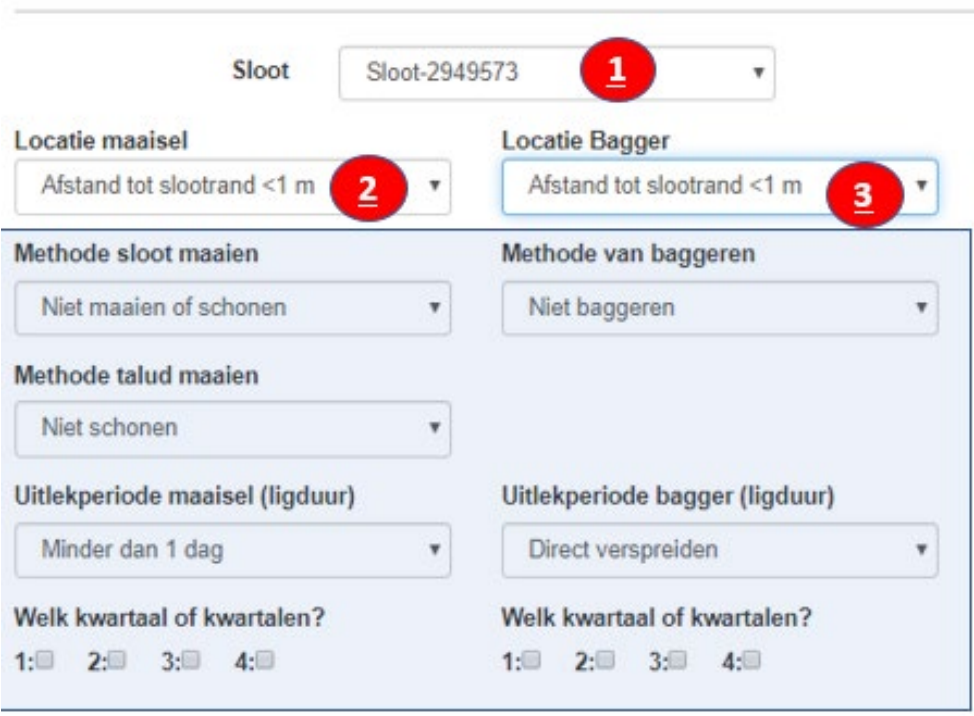

\section{Terug Bewaar}

\section{(c) 2019 - WUR}

Het scherm "Sloot-specifieke gegevens (voor afwijkende schoning strategie):

- Klik op 'Wijzig' als de eerder ingevoerde gegevens gewijzigd dienen te worden. Het scherm waarin eerder de gegevens zijn ingevoerd verschijnt. De gegevens kunnen gewijzigd worden.

- Klik op 'Terug' als de gegevens toch niet gewijzigd hoeven te worden.

- Klik op 'Bewaar' als de gewijzigde gegevens bewaard moeten worden.

- Klik op 'Verwijder' als de eerder ingevoerde gegevens verwijderd dienen te worden. Het scherm "Verwijderen, Weet u zeker dat u de schoningsstrategie voor deze individuele sloot wilt verwijderen?".

Sloot-specifieke gegevens (voor afwijkende schoning strategie)

\section{Nieuwe Slootstrategie}

\begin{tabular}{|l|l|l|l|l|}
\hline Slootnaam & Locatie maaisel & Locatie Bagger & Optie \\
Sloot-2949573 & Afstand tot slootrand $<1 \mathrm{~m}$ & Afstand tot slootrand $<1 \mathrm{~m}$ & Wizig & Vermijder \\
\hline
\end{tabular}

() 2019 - WUR

- Klik op 'Terug' als u de ingevoerde gegevens toch niet wilt verwijderen.

- Klik op 'Verwijder' als u de ingevoerde gegevens wilt verwijderen.

\section{Verwijderen}

Weet u zeker dat u de schoningsstrategie voor deze individuele sloot wilt verwijderen? DataModule7 
Bij beide keuzes wordt terug gekeerd naar het voorgaande scherm "Slootbeheer, Bedrijfsgegevens voor sloot schoning" met daaronder het scherm "Sloot-specifieke gegevens (voor afwijkende strategie)".

$\mathrm{Na}$ invullen van de "Bedrijfsgegevens voor sloot schoning" en "Sloot-specifieke gegevens (voor afwijkende schoning strategie)":

- Klik op 'Terug'. Het hoofdscherm van de module "Slootbeheer" verschijnt.

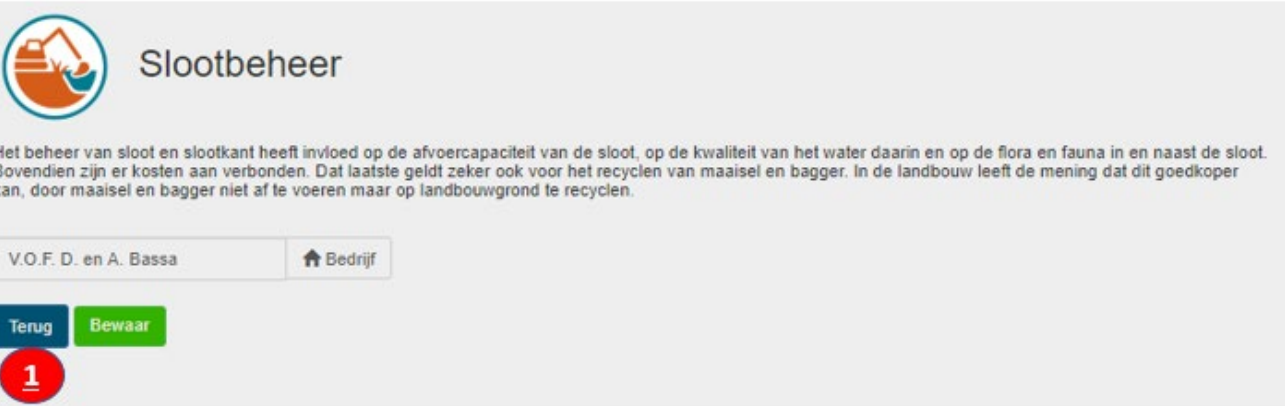

Bedrijfsgegevens voor sloot schoning

Deze gegevens gelden voor uw hele bedrif. Afwipkingen hierop kunt u per perceel hieronder apart invullen

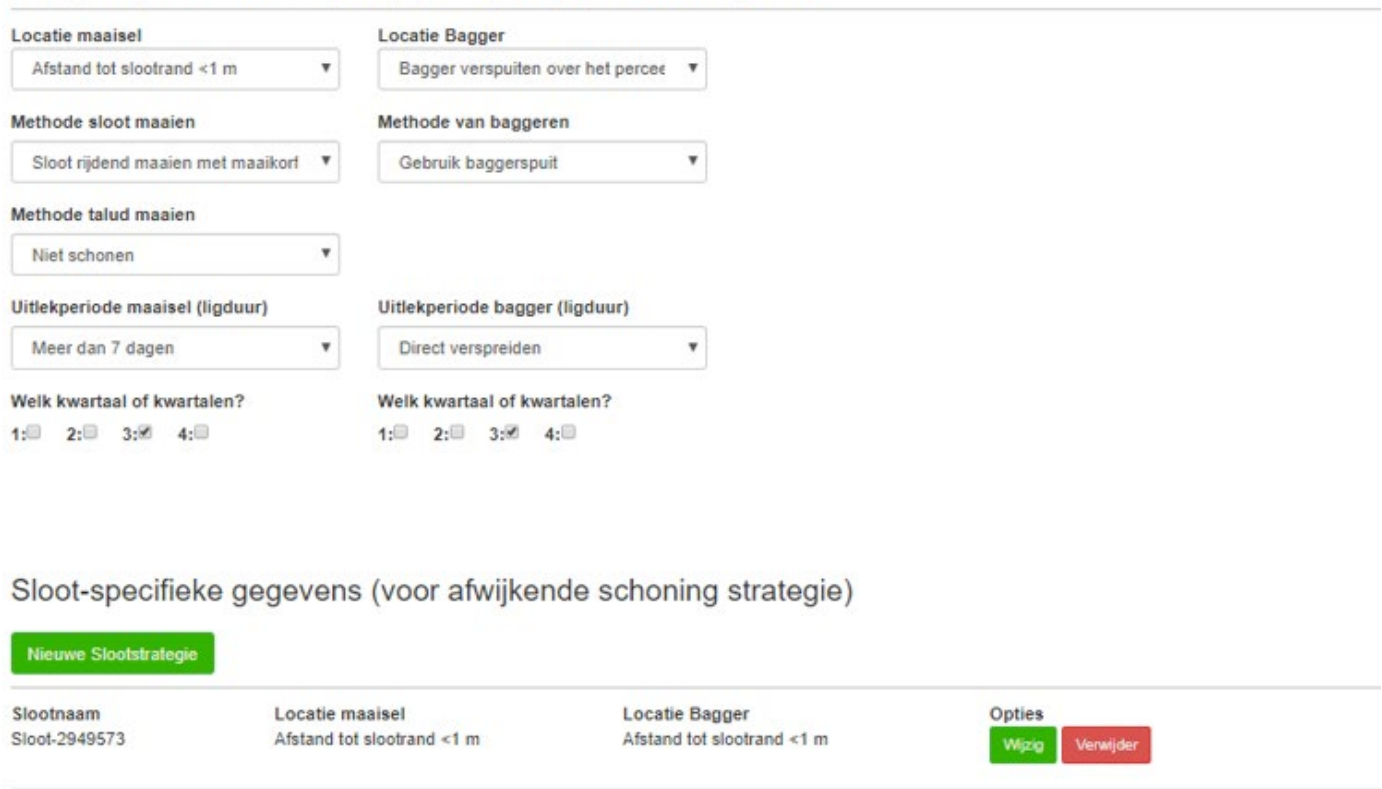

2019 - WUR

- Klik op "Laatste Stap Naar Resultaten $\rightarrow$ "

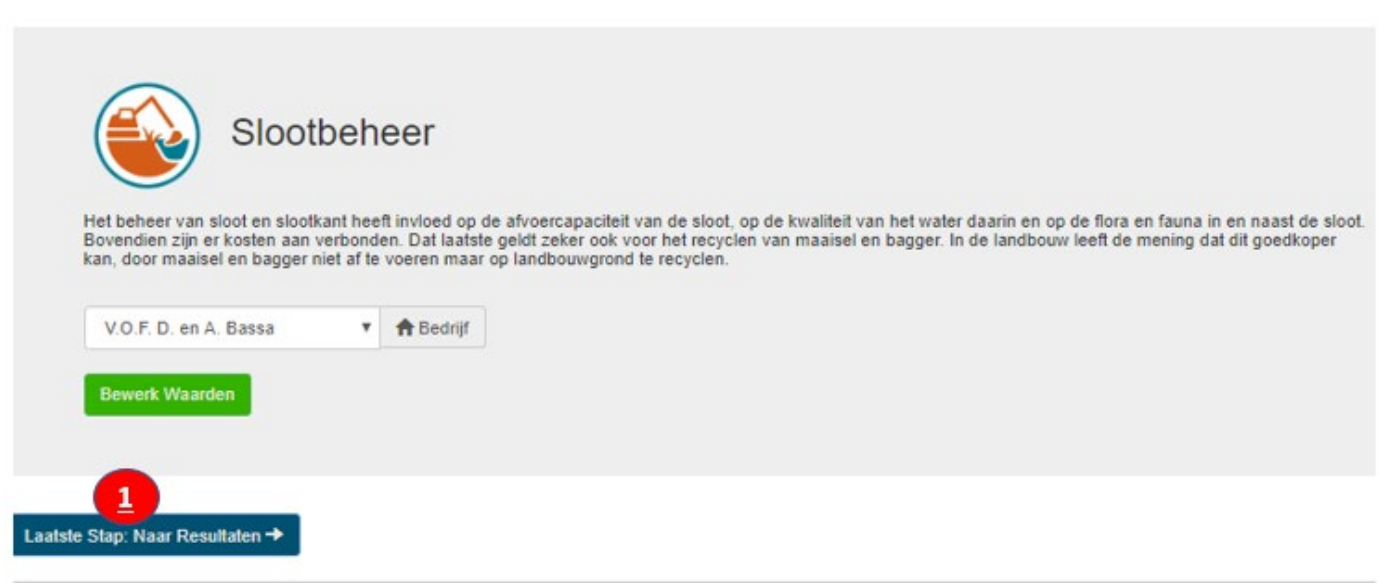


Een scherm met de resultaten in kleurbalken per ingevoerde module verschijnt.

In deze uitgave van de handleiding wordt geen uitleg en onderbouwing van de resultaten beschreven. Alleen de invoer van de bedrijfsgegevens wordt behandeld. 


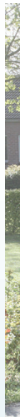
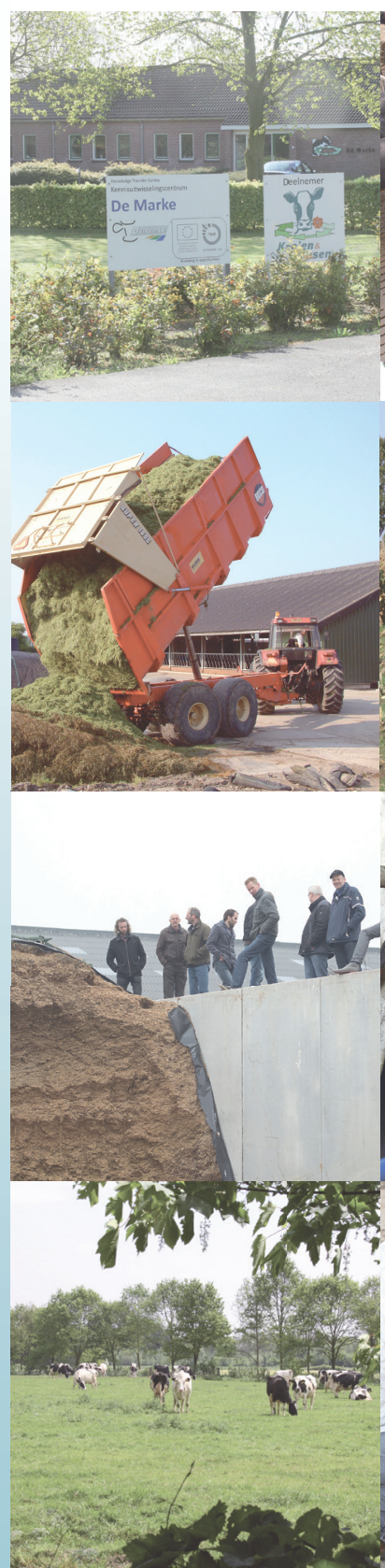

Secretariaat Koeien \& Kansen

Postbus 338

$6700 \mathrm{AH}$ Wageningen

T (0317) 480177

E info@koeienenkansen.nl

www.koeienenkansen.nl

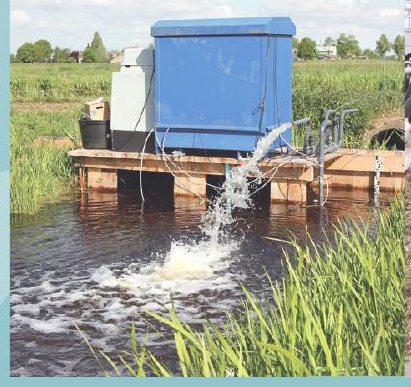

